\title{
CONTEMPORARY ECONOMICS
}

Quarterly of University of Finance and Management in Warsaw

Volume 5 Issue 3

September 2011

SPECIAL ISSUE

\section{SOCIAL DIAGNOSIS 2011}

OBJECTIVE AND SUBJECTIVE QUALITY OF LIFE IN POLAND

\section{DIAGNOZA SPOŁECZNA 2011 WARUNKI I JAKOŚĆ ŻYCIA POLAKÓW}

Edited by: Janusz Czapiński and Tomasz Panek

Raport Diagnoza Społeczna 2011 finansowany przez:

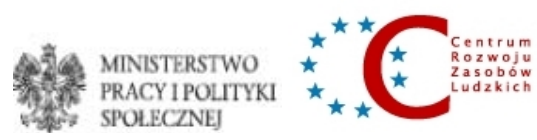

UNIA EUROPEJSKA
EUROPEJSKI FUNDUSZ SPOLECZNNY
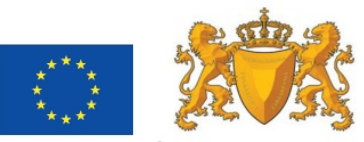


\section{CONTEMPORARY ECONOMICS}

ABSTRACTED/INDEXED:

- Cabell's Directories

- ECONIS

- EconStor

- GALE Science in Context

- Ministry of Science and Higher Education list of scored journals (rating score 9 pts)

- Research Papers in Economics (RePEc)

- SCOPUS

- The Central European Journal of Social Sciences and Humanities

- The International Bibliography of the Social Sciences (IBSS)/ProQuest

- Ulrichsweb

Contemporary Economics is published with the financial support of Polish Ministry of Science and Higher Education, in the frame of research supporting activity and programme INDEX PLUS.

\section{Academic Board}

Icek Ajzen (USA)

Damodaran Appukuttan Nair (India)

Zenon Biniek (Poland)

Constantin A. Bob (Romania)

Wiesław Dębski (Poland)

Bruno S. Frey (Switzerland)

Masahiko Gemma (Japan)

Kjell Åge Gotvassli (Norway)

Adriana Grigorescu (Romania)

Zoran Ivanovic (Croatia)

Sten Jönsson (Sweden)

Victor Martinez Reyes (USA)

Ieva Meidute (Lithuania)

Fatmir Memaj (Albania)

Grażyna Rytelewska (Poland)

Shelby D. Hunt (USA)

Maria Sierpińska (Poland)

President of Academic Board

Miemie Struwig (South Africa)

Tadeusz Szumlicz (Poland)

\section{Editorial Board}

Witold Jakóbik

Henryk Król

Editor in Chief

Witold Małecki

Danuta Mliczewska

Deputy Editor in Chief

Włodzimierz Rembisz

Marcin Staniewski

Deputy Editorial Manager

Piotr Szczepankowski

Editorial Manager

Ryszard Wilczyński

\section{Address of Editors:}

\section{CONTEMPORARY ECONOMICS}

University of Finance and Management in Warsaw

01 - 030 Warsaw, 55 Pawia Str., room 211, phone: (22) 5365454

e-mail: editorial@ce.vizja.pl

www.ce.vizja.pl

Publisher:

Vizja Press \& IT

$01-029$ Warsaw, 60 Dzielna Str.

phone/fax: (22) 5365468

e-mail: vizja@vizja.pl

www.vizja.net.pl

All articles published in the quarterly are subject to reviews 


\section{KORZYSTANIE Z TECHNOLOGII INFORMACYJNO-KOMUNIKACYJNYCH}

Dominik Batorski

Technologie informacyjno-komunikacyjne, choć wciąż czasem określane mianem "nowych technologii" spowszedniały. Dla większości Polaków telefon komórkowy jest narzędziem codziennego użytku, coraz więcej osób korzysta też z komputerów i internetu. Jeszcze kilka lat temu technologie te były używane wyłącznie przez niewielką grupę osób. W 2003 roku zaledwie 14 proc. osób w wieku 16 i więcej lat korzystało zarówno z telefonów komórkowych, komputerów i internetu. Obecnie komórkę posiada ponad 85 proc., z sieci korzysta 60 proc., a 55 proc. korzysta ze wszystkich tych technologii. Jednak od samego upowszechnienia technologii ICT istotniejsze jest wzrost znaczenie tych technologii w różnych sferach życia, a także dla przemian społecznych i gospodarczych w Polsce. Niniejszy rozdział Diagnozy społecznej poświęcony jest diagnozie stanu rozwoju społeczeństwa informacyjnego w Polsce oraz uwarunkowań, sposobów, a także konsekwencji korzystania z nowych technologii informacyjno-komunikacyjnych.

\subsection{Nowe technologie w gospodarstwach domowych}

\subsubsection{Komputery i dostęp do internetu}

W pierwszej połowie 2011 roku w dwóch trzecich gospodarstw domowych był komputer, natomiast dostęp do internetu w 61,1 proc. Obserwujemy dalszy wzrost liczby skomputeryzowanych gospodarstw domowych, choć jest on coraz wolniejszy (wykres 7.1.1). Spowolnienie to świadczy o stopniowym nasycaniu się rynku, tak jak przewidywaliśmy w raporcie sprzed dwóch lat. Z drugiej strony, wzrost dostępności internetu jest cały czas szybki i w ostatnich dwóch latach liczba gospodarstw domowych z dostępem do sieci zwiększyła się o prawie 10 p.p. Jest to związane z kurczeniem się grupy gospodarstw, które posiadają komputer, ale nie mają dostępu do internetu. Obecnie internetu nie ma tylko 8 proc. skomputeryzowanych, dwa lata temu było to 15 proc. a w 2003 roku dostęp do sieci miało tylko co drugie gospodarstwo wyposażone w komputer.

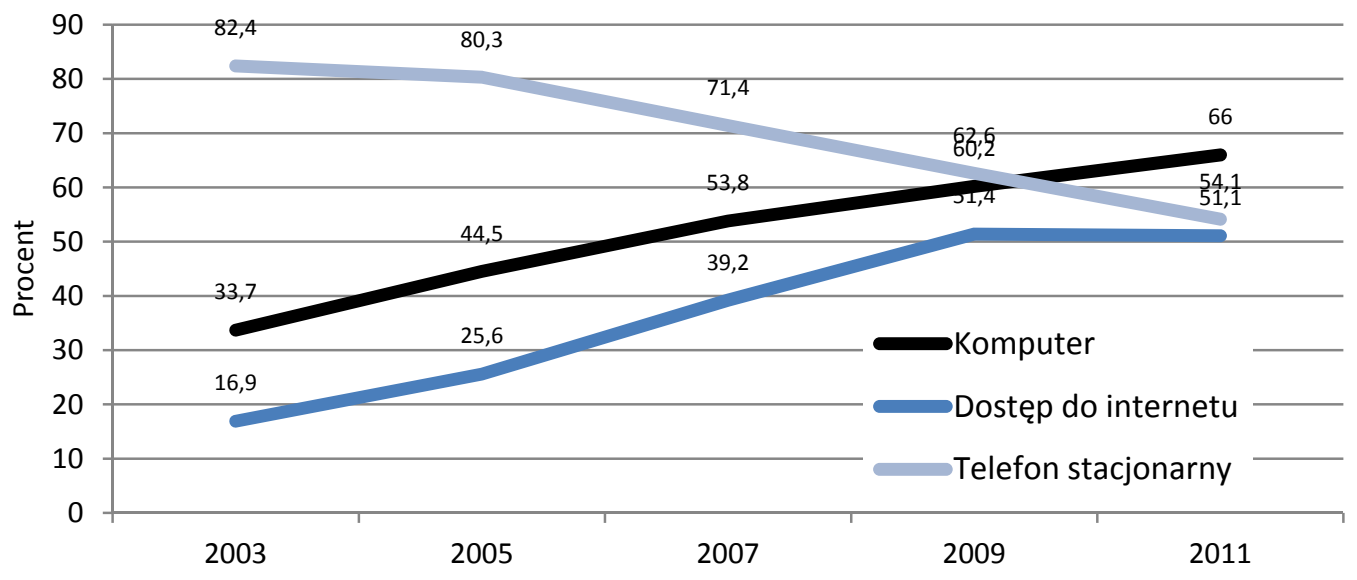

Wykres 7.1.1. Wyposażenie gospodarstw domowych w komputer, dostęp do internetu i telefon stacjonarny w latach 2003-2009.

Wśród gospodarstw domowych, w których nie ma komputerów i internetu, tylko część tłumaczy brak względami finansowymi. Obecnie 10,3 proc wszystkich gospodarstw domowych nie ma komputera ze względów finansowych, a 9,5 proc. nie ma internetu $z$ tego powodu.

Nieco ponad połowa (50,2proc.) gospodarstw domowych posiada komputer stacjonarny. Laptop, netbook lub tablet jest w 38,8 proc. gospodarstw. Zmiany widoczne są praktycznie wyłącznie w tej drugiej kategorii. Liczba gospodarstw domowych $\mathrm{z}$ komputerem stacjonarnym była praktycznie identyczna cztery lata temu i nawet nieco wyższa w 2009 roku (51,3proc.). Znacząco rośnie natomiast udział gospodarstw domowych z laptopami, które są sprzedawane znacznie częściej niż komputery stacjonarne. Dwa lata temu laptopy były w 25 proc. gospodarstw, a w 2007 roku ledwie w 11 proc. Większa liczba laptopów nie oznacza jednak większej mobilności ich wykorzystania. Są one używane przede wszystkim w domu, a użytkownicy preferują je często ze względu na to, że zabierają mniej miejsca i dają większą swobodę wykorzystania.

Zwiększa się liczba komputerów w poszczególnych gospodarstwach domowych. Obecnie więcej niż jeden komputer posiada 27,8 proc. wszystkich gospodarstw, dwa lata temu było to 17 proc. a w 2007 ledwie 10 proc. Trzy 
lub więcej komputerów jest w 5,2 proc. gospodarstw. W 13 proc. gospodarstw komputerów jest przynajmniej tyle ile osób. W wyposażonych gospodarstwach na jeden komputer przypada średnio 2,7 osoby (w 2007 było to aż 3,5).

Podobnie jak w ubiegłych latach, komputer częściej posiadają gospodarstwa wieloosobowe, a zdecydowanie najrzadziej osoby mieszkające samotnie. Aż 72 proc. tych ostatnich nie posiada w domu komputera, w gospodarstwach domowych, w których mieszkają dwie osoby, komputera nie ma 49 proc. Tymczasem, komputer jest w 84 proc. domów, w których mieszkają trzy osoby i aż w 90 proc. gospodarstw zamieszkiwanych przez cztery i więcej osób. Różnice te powodują, że już 75,6 proc. Polaków w wieku 16 i więcej lat ma komputer we własnym domu (wzrost z niecałych 70 proc. dwa lata temu i 62 proc. w 2007 roku). Podobnie jest z dostępem do internetu, dzięki czemu już 70,5 proc. Polaków w wieku 16+ posiada w domu komputer z dostępem do sieci (dwa lata temu było to o 11 p.p. mniej). Jeżeli uwzględnimy również dzieci poniżej 16-tego roku życia, to okaże się, że dostęp w domu ma 73 proc. mieszkańców kraju.

Jednak nie wszyscy, których gospodarstwa domowe posiadają technologie ICT, faktycznie z nich korzystają. Aż 23 proc. osób, które posiadają komputer w domu, zupełnie z komputerów nie korzysta. Co więcej, osób takich jest coraz więcej - w 2007 roku nie korzystało 16 proc. osób mających komputer w domu, a dwa lata później 17 proc. Z domowych komputerów nie korzystają przede wszystkim osoby starsze, słabiej wykształcone, a także emeryci i renciści. Mniej domowników korzysta z komputerów w małych miastach i na wsi. Analogicznie, jak w przypadku komputerów, również z internetu nie korzysta znacząca grupa osób posiadających komputer i dostęp do sieci we własnym domu. Obecnie jest to 14,1 proc. Polaków w wieku 16+ i 19 proc. tych, którzy posiadają dostęp.

Dla bardzo dużej i wciąż rosnącej grupy osób powodem niekorzystania z komputerów i internetu nie jest brak dostępu do tych technologii. Nie korzystają one przede wszystkim ze względu na brak motywacji do samodzielnego używania (często mogą poprosić o pomoc lub sprawdzenie czegoś w sieci innych domowników). Znaczenie ma również brak wiedzy, do czego internet mógłby się przydać, a także brak umiejętności korzystania.

Zdecydowana większość gospodarstw domowych z dostępem do internetu łączy się z nim za pomocą stałego łącza. Taki rodzaj dostępu ma obecnie już ponad połowa wszystkich gospodarstw domowych (50,1 proc.). Modemy łączące się z internetem przez zwykłe linie telefonii stacjonarnej odeszły w przeszłość - praktycznie nikt z nich już nie korzysta. Już cztery lata temu było to tylko 5 proc. gospodarstw z internetem, podczas gdy w 2003 roku stałe łącze posiadało tylko kilkanaście procent gospodarstw domowych łączących się z siecią.

Ostatnie lata to również upowszechnienie dostępu mobilnego - już 15 proc. łączących się z internetem posiada dostęp od operatora telefonii komórkowej, a dalsze 3 proc. wykorzystuje do łączenia się $\mathrm{z}$ siecią telefon komórkowy. Coraz mniejszy udział w dostarczaniu dostępu do sieci mają operatorzy telefonii stacjonarnej. Jest to związane z malejącym udziałem neostrady Telekomunikacji Polskiej, ponieważ łącza oferowane przez innych operatorów są w coraz większej liczbie podłączonych gospodarstw. Nie zmienia się praktycznie udział łączy oferowanych przez dostawców telewizji kablowej, którzy rosną wraz z rynkiem i docierają cały czas do 27 proc. gospodarstw z internetem. Coraz mniej popularne są natomiast sieci osiedlowe i usługi lokalnych dostawców internetu.

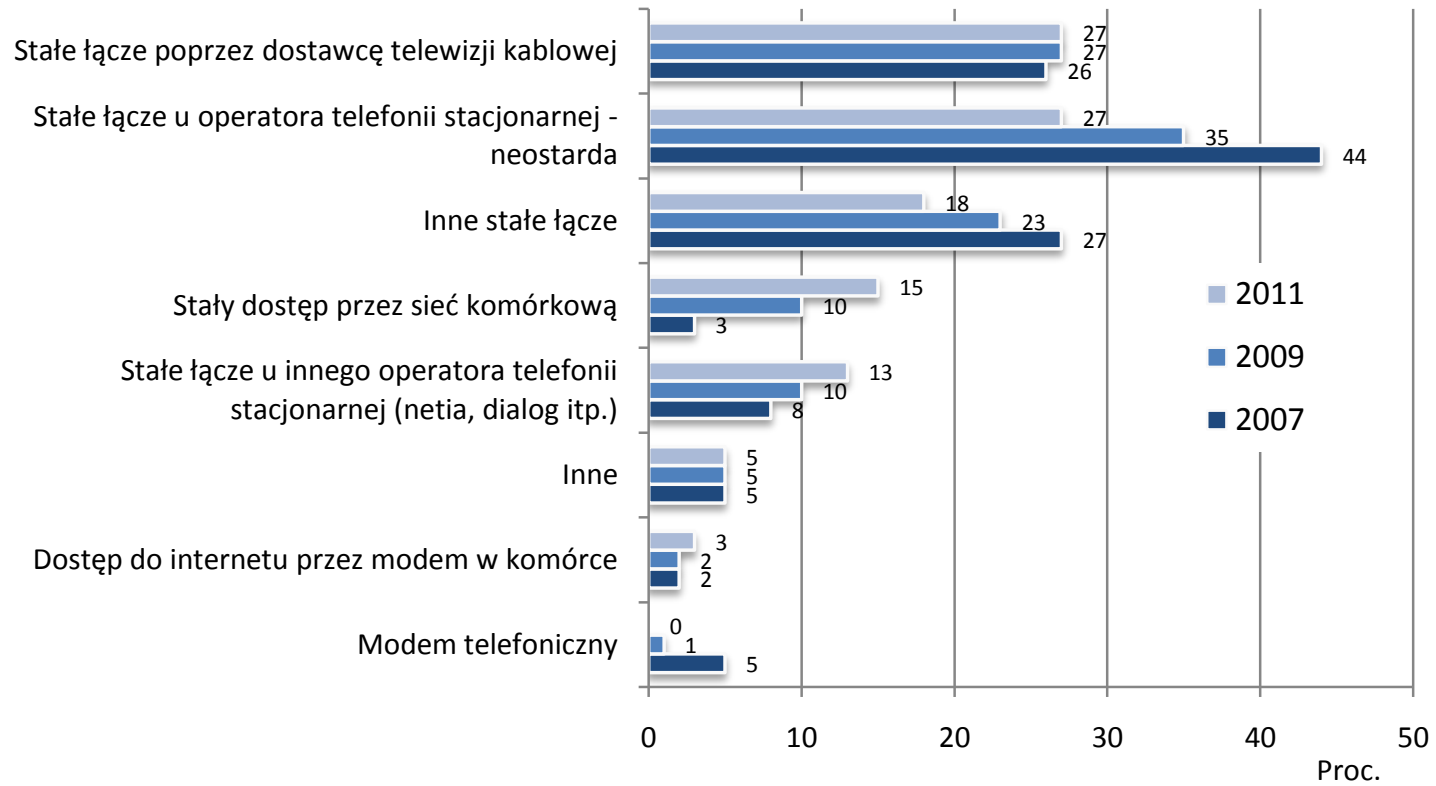

Wykres 7.1.2. Sposoby łaczenia się z internetem w podłaczonych gospodarstwach domowych w latach 2007-2011.

Najważniejszą zmianą dotyczącą sposobu dostępu do internetu jest niewątpliwie upowszechnienie dostępu mobilnego. Warto nieco bliżej się temu przyjrzeć. Coraz większy odsetek gospodarstw wykorzystuje telefonię komórkową do łączenia się z internetem, obecnie jest to 9 proc. wszystkich gospodarstw domowych, czyli 15 proc. 
tych z dostępem. Przyrost takich gospodarstw w ostatnich latach był bardzo duży. Aż dla 83 proc. z wykorzystujących ten rodzaj dostępu jest to jedyny sposób łączenia się z siecią. Jego użycie ma często stacjonarny charakter i wynika z niemożliwości założenia innego stałego łącza w gospodarstwie, a niekoniecznie z potrzeby mobilnego użycia. Tym samym, duża liczba gospodarstw łączących się z siecią w ten sposób świadczy pośrednio o słabej dostępności internetu na wielu terenach. Z drugiej strony, upowszechnienie dostępu mobilnego wraz ze wzrostem powszechności komputerów przenośnych może z czasem przyczynić się do bardziej mobilnego korzystania $\mathrm{z}$ internetu.

Dostęp do internetu przez komórkę jest wykorzystywany inaczej niż stały dostęp oferowany przez operatorów sieci komórkowych. Jest on raczej uzupełnieniem i dodatkowym sposobem dostępu niż dostępem jedynym. Aż 80 proc. wykorzystujących go, ma inny rodzaj dostępu w domu (zdecydowana większość stałe łącze), pozostali na ogół korzystają z internetu również w innych miejscach (np. pracy).

Przepustowość domowych stałych łączy oraz dynamikę ich zmiany w latach 2007-2011 pokazuje wykres 7.1.3. Rodzaj dostępu do sieci jest istotny, ponieważ ma znaczenie dla możliwości korzystania z internetu. Polska pod tym względem jest cały czas w tyle za przodującymi krajami UE. Najpopularniejsze są łącza o przepustowości 2Mb/s, choć dużo jest jeszcze łączy o przepustowości $1 \mathrm{Mb} / \mathrm{s}$. Stopniowo upowszechniają się również łącza o znacznie większej przepustowości. Generalnie, wzrost jakości łączy był w ostatnich latach bardzo duży. Zdecydowanie maleje udział najwolniejszego dostępu. Łącza $6 \mathrm{Mb} / \mathrm{s}$ i więcej ma 28 proc. gospodarstw domowych z internetem, podczas gdy jeszcze dwa lata temu było to zaledwie niecałe 7 proc. posiadających stałe łącze.

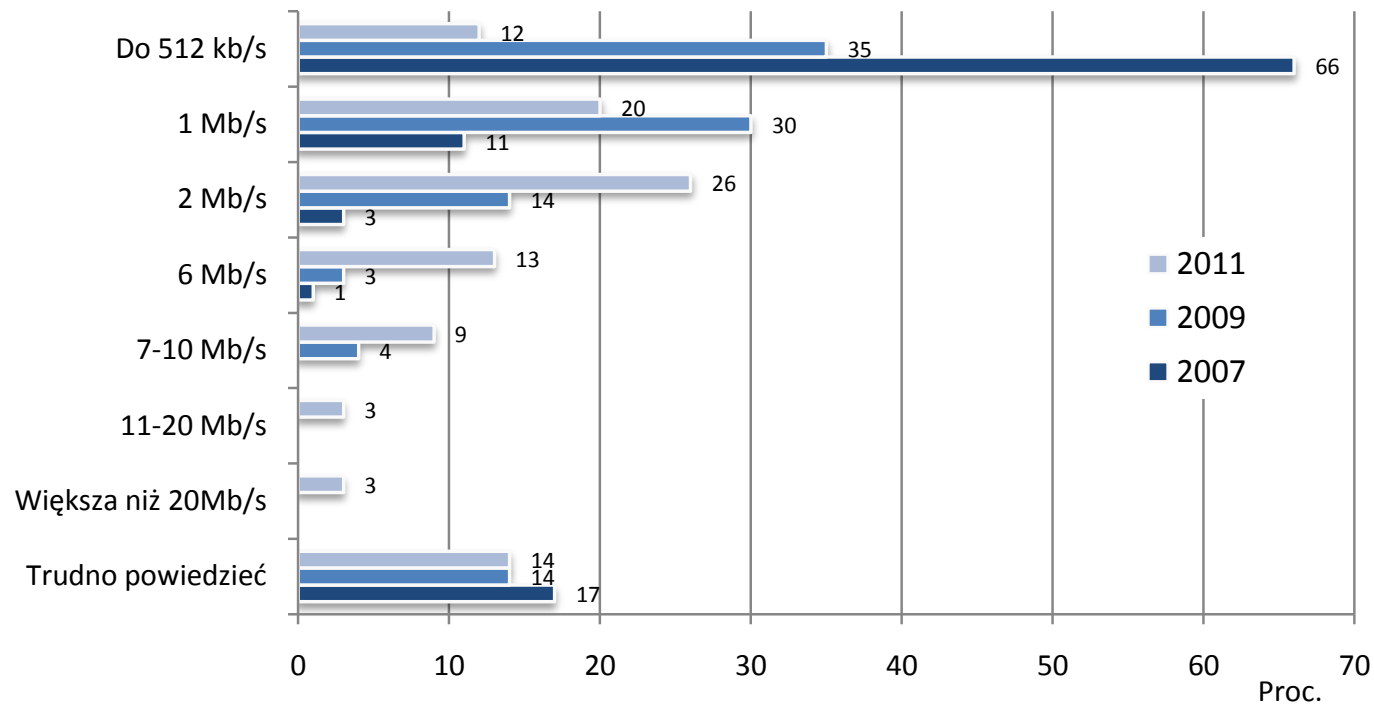

Wykres 7.1.3. Przepustowość taczy internetowych $w$ gospodarstwach domowych ze statym łaczem internetowym $w$ latach 2007-2011.

\subsubsection{Inne technologie w gospodarstwach domowych}

W ostatnich dwóch latach obserwujemy bardzo duży przyrost liczby gospodarstw posiadających płatną telewizję satelitarną lub kablową (wykres 4.3.16 w rozdz. 4.3). W ostatnich czterech latach nastąpił także bardzo szybki przyrost telewizorów LCD lub plazmowych. Jest on wyraźnie szybszy niż przyrost komputerów i dostępności internetu w ostatnich latach. W 2007 takie telewizor miało zaledwie co piąte gospodarstwo domowe, dwa lata temu co trzecie, a obecnie już połowa. Również odtwarzacze DVD są coraz częstsze w gospodarstw domowych Polaków, jednak dynamika przyrostu jest znacznie wolniejsza. Rośnie także odsetek gospodarstw deklarujących posiadanie kina domowego.

Nadal maleje liczba gospodarstw domowych posiadających telefon stacjonarny. Obecnie jest ich nieco ponad połowa. Oczywiście wynika to przede wszystkim z upowszechnienia telefonii komórkowej - obecnie telefon komórkowy posiadają osoby z 87,9 proc. gospodarstw domowych, a więc komórki są w znacznie większej liczbie gospodarstw domowych niż telefony stacjonarne. W aż 57,7 proc. gospodarstw telefon komórkowy ma każda osoba. Własny telefon komórkowy ma 85,1 proc. osób w wieku 16 i więcej lat. Wśród osób, które nie mają telefonu komórkowego, 10,1 proc. ma w domu telefon stacjonarny. Zaledwie 4,8 proc. to osoby, które nie mają ani własnej komórki, ani telefonu stacjonarnego.

\subsubsection{Uwarunkowania obecności nowych technologii w gospodarstwach domowych}

Jak już zostało wspomniane wcześniej obecność komputerów i internetu w gospodarstwach domowych jest bardzo zróżnicowana w zależności od kilku czynników. W tabeli 7.1.1 umieszczone zostały dane o dostępności tych technologii w gospodarstwach różnego typu dla lat 2007- 2011. 
Tabela 7.1.1. Dostępność komputerów i internetu w różnych typach gospodarstw domowych w latach 2007-2011.

\begin{tabular}{|c|c|c|c|c|c|c|c|}
\hline \multirow{2}{*}{\multicolumn{2}{|c|}{ Grupa gospodarstw }} & \multicolumn{3}{|c|}{ komputer } & \multicolumn{3}{|c|}{ internet } \\
\hline & & 2007 & 2009 & 2011 & 2007 & 2009 & 2011 \\
\hline \multirow{6}{*}{$\begin{array}{l}\text { Wielkość } \\
\text { miejscowości } \\
\text { zamieszkania }\end{array}$} & Miasta powyżej 500 tys. & 67,4 & 70,8 & 77,1 & 57,6 & 65,4 & 73,3 \\
\hline & Miasta $200-500$ tys. & 60,8 & 69,2 & 71,9 & 50,2 & 63,0 & 68,7 \\
\hline & Miasta $100-200$ tys. & 55,9 & 61,8 & 67,1 & 44,3 & 55,8 & 64,6 \\
\hline & Miasta $20-100$ tys. & 55,7 & 60,4 & 66,5 & 44,2 & 52,9 & 62,0 \\
\hline & Miasta poniżej 20 tys. & 53,3 & 57,8 & 65,0 & 40,4 & 50,2 & 61,4 \\
\hline & Wieś & 44,2 & 52,8 & 58,9 & 22,4 & 39,4 & 51,7 \\
\hline \multirow[t]{2}{*}{ Region } & Województwa ściany wschodniej & 48,2 & 55,2 & 63,0 & 30,7 & 43,9 & 56,8 \\
\hline & Pozostałe województwa & 55,4 & 61,5 & 66,7 & 41,5 & 53,3 & 62,1 \\
\hline \multirow[t]{8}{*}{ Typ rodziny } & Małżeństwa bez dzieci & 28,1 & 42,5 & 50,6 & 22,4 & 35,9 & 47,8 \\
\hline & Małżeństwa z 1 dzieckiem & 70,0 & 82,5 & 87,2 & 53,5 & 72,3 & 81,7 \\
\hline & Małżeństwa z 2 dzieci & 80,5 & 89,7 & 93,5 & 61,5 & 78,2 & 87,4 \\
\hline & Małżeństwa z 3 i więcej dzieci & 75,2 & 86,6 & 90,7 & 47,3 & 70,4 & 84,3 \\
\hline & Rodziny niepełne & 53,5 & 64,3 & 72,4 & 37,8 & 53,2 & 65,8 \\
\hline & Wielorodzinne & 65,5 & 78,0 & 87,1 & 38,3 & 63,3 & 78,5 \\
\hline & Nierodzinne jednoosobowe & 19,6 & 26,3 & 28,1 & 15,8 & 22,8 & 25,0 \\
\hline & Nierodzinne wieloosobowe & 43,1 & 51,8 & 54,8 & 28,1 & 40,0 & 52,9 \\
\hline \multirow{4}{*}{$\begin{array}{l}\text { Dochód na } \\
\text { jednostkę } \\
\text { konsumpcji } \\
\text { w gosp. dom. }\end{array}$} & Do pierwszego kwartyla & 39,0 & 44,8 & 48,1 & 19,1 & 32,8 & 41,1 \\
\hline & Od pierwszego do drugiego kwartyla & 45,1 & 49,3 & 59,3 & 30,7 & 40,2 & 54,1 \\
\hline & Od drugiego do trzeciego kwartyla & 55,0 & 61,8 & 66,2 & 41,7 & 53,4 & 62,3 \\
\hline & Powyżej trzeciego kwartyle & 70,5 & 81,6 & 86,5 & 60,1 & 75,8 & 83,3 \\
\hline
\end{tabular}

Dostępność komputerów i internetu w gospodarstwach domowych jest w bardzo dużym stopniu zależna od typu rodziny. Około 90 proc. małżeństw z dziećmi posiada komputer, a niewiele mniej również dostęp do internetu. Zupełnie inaczej wygląda sytuacja $\mathrm{w}$ gospodarstwach jednoosobowych, w których komputer i internet są zdecydowanie najrzadszej - dostęp do sieci ma zaledwie co czwarta osoba mieszkająca samotnie. Technologie ICT znacznie rzadziej niż przeciętnie mają też małżeństwa bez dzieci, internet posiada mniej niż połowa $\mathrm{z}$ nich. W przypadku obu tych grup mniejsza obecność technologii związana jest z tym, że są to przede wszystkim gospodarstwa osób starszych. Warto też zauważyć, że sytuacja rodzin niepełnych jest wyraźnie gorsza niż sytuacja małżeństw z dziećmi. Różnica, podobnie jak dwa lata temu, wynosi około 20 p.p.

Podkreślić należy, że w ostatnich latach różnice raczej się pogłębiały niż malały. Zdecydowanie najsłabiej poprawia się sytuacja gospodarstw jednoosobowych. W ostatnich czterech latach dostępność internetu zwiększyła się w tej grupie zaledwie o 10 p.p., podczas gdy na przykład wśród małżeństw z trójką dzieci aż o 37 p.p. Obecność dzieci w wieku szkolnym, niezmiennie ma olbrzymie znaczenie dla posiadania nowych technologii w gospodarstwie domowym. Do tego zagadnienia wrócimy jeszcze w ostatniej części rozdziału omawiającej korzystanie z komputerów i internetu przez dzieci.

Spore znaczenie dla wyposażenia gospodarstw domowych w komputery i dostęp do internetu ma także klasa miejscowości zamieszkania i dochody. Nowe technologie są częściej obecne w większych miejscowościach i gospodarstwach o wyższych dochodach. Większe zróżnicowanie występuje pod względem dostępności internetu. W największych miastach dostęp posiada 73 proc. gospodarstw, a na wsi jedynie 52 proc. Różnica pomiędzy jedną czwartą gospodarstw domowych o najwyższych dochodach, a tymi o dochodach najniższych jest ponad dwukrotna. Jednocześnie w ostatnich latach zdecydowanie najszybciej rosła dostępność internetu na wsi (prawie o 30 p.p.) i w małych miastach (o 21 p.p.). Różnice pomiędzy miastem i wsią zmniejszają się. W niewielkim stopniu zmieniają się natomiast różnice związane $\mathrm{z}$ dochodami. W ostatnich czterech latach przyrosty nowych użytkowników w tych grupach były podobne.

Znaczące są także różnice $\mathrm{w}$ dostępie do internetu w gospodarstwach domowych pomiędzy różnymi województwami, choć i one maleją (wykresy 7.1.4 i 7.1.5). Obecnie najlepsza sytuacja jest w województwie małopolskim, gdzie dostęp do internetu ma prawie dwie trzecie gospodarstw domowych. Podobnie jest $\mathrm{w}$ województwie wielkopolskim. Najrzadziej dostęp do sieci mają mieszkańcy województwa świętokrzyskiego, a także województw lubelskiego i łódzkiego.

Jak pokazuje tabela 7.1.1 istnieje też znaczna różnica między województwami ściany wschodniej i resztą kraju. W pięciu województwach wschodniej Polski dostęp do internetu ma niecałe 57 proc. gospodarstw, a w pozostałych regionach 62 proc. Należy jednak podkreślić, że różnice te maleją. Jeszcze dwa lata temu wynosiły prawie 10 p.p., wcześniej jeszcze więcej, a obecnie już tylko 5 p.p. Tym samym, mimo iż program budowy sieci szerokopasmowych w województwach ściany wschodniej jeszcze na dobre nie ruszył, to i bez tego różnice się zmniejszają. W województwie pomorskim, w którym dotychczas było zdecydowanie najwięcej podłączonych gospodarstw, ostatnie dwa lata nie przyniosły dużej zmiany. Natomiast w województwach świętokrzyskim, czy warmińsko-mazurskim, gdzie było znacznie gorzej, nastąpił duży przyrost dostępności internetu. 


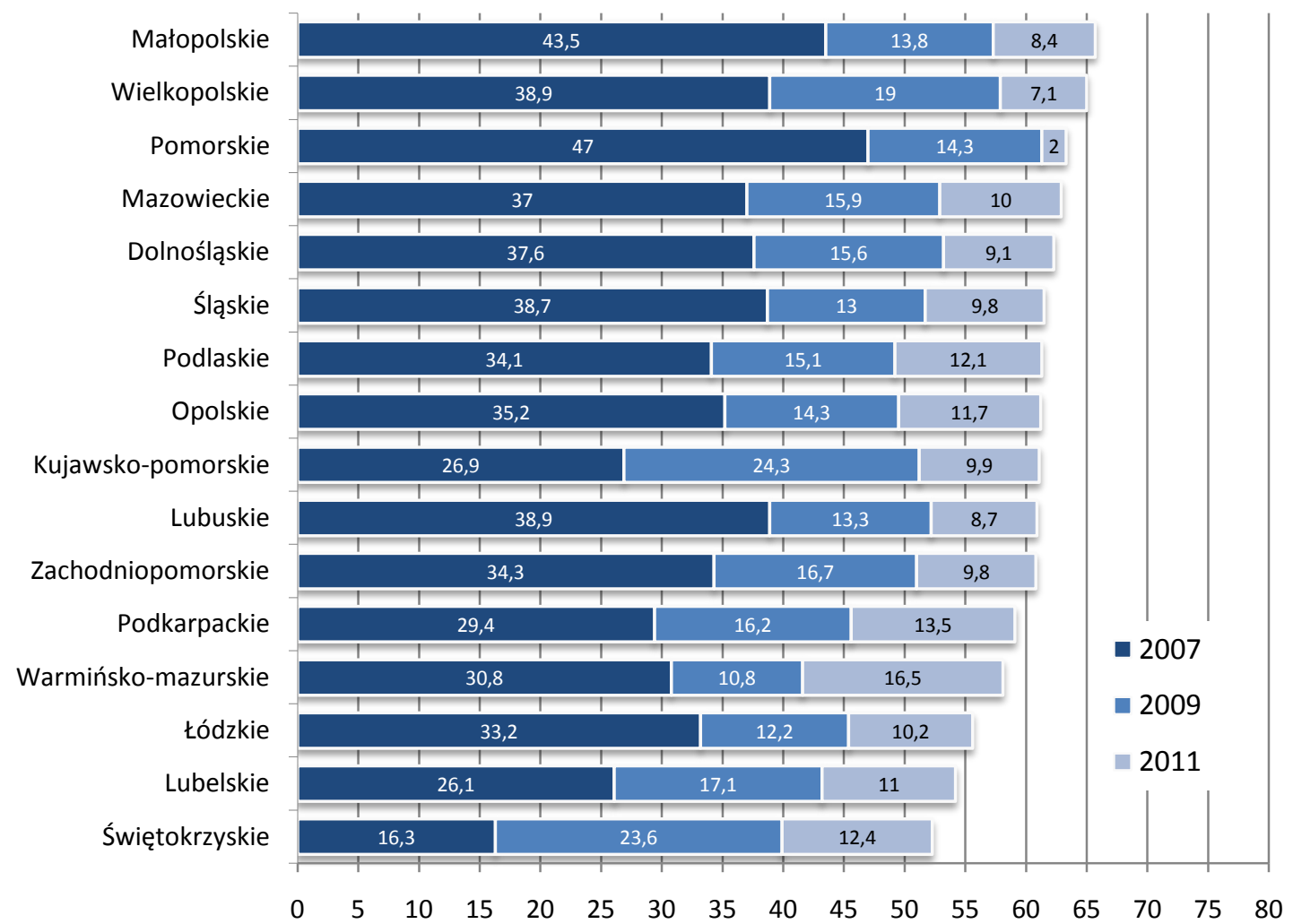

Wykres 7.1.4. Procent gospodarstw domowych z dostępem do internetu w przekroju wojewódzkim w 2007 r. $i$ dodatkowy procent gospodarstw $z$ dostepem do internetu w latach 2009 i 2011

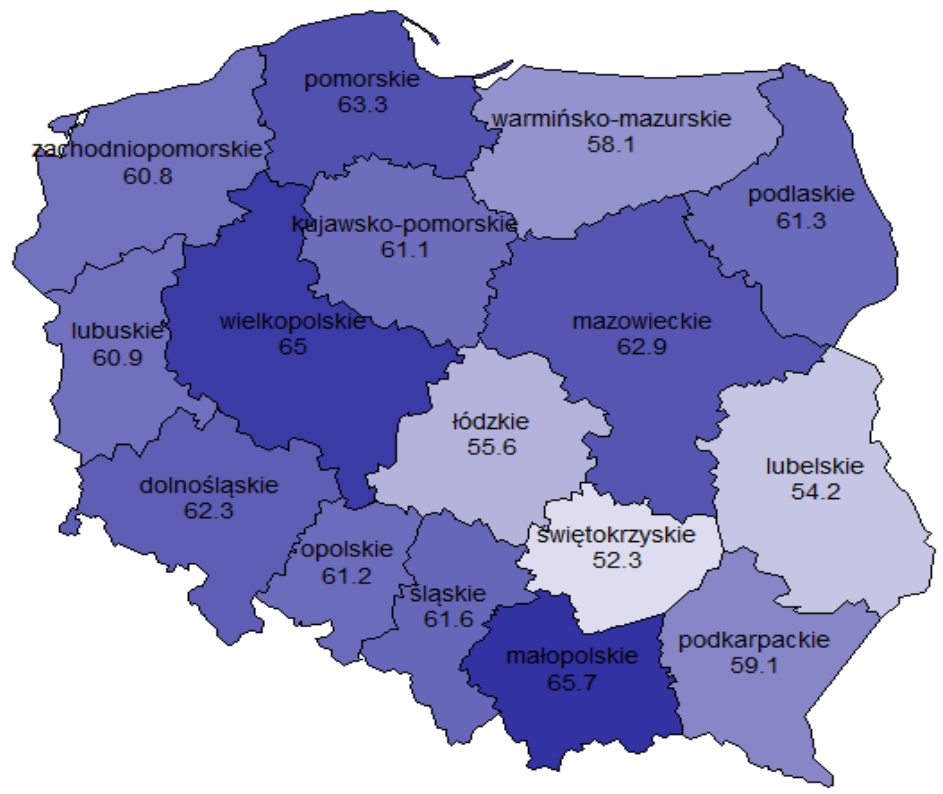

Wykres 7.1.5. Procent gospodarstw domowych z dostępem do internetu w województwach.

\subsubsection{Przyczyny braku technologii ICT w gospodarstwach domowych}

Brak powszechnej dostępności technologii ICT jest dostrzegany przez samorządy, administrację państwową, a także niektóre firmy i często postrzegany jest jako problem: albo jako istotny czynnik wykluczenia cyfrowego, albo też jako ograniczenie dostępu do usług, w tym usług publicznych świadczonych drogą elektroniczną. Podejmowanych jest szereg inicjatyw i działań na rzecz upowszechnienia wykorzystania komputerów i internetu. Aby jednak możliwe było podejmowanie działań adekwatnych do danego problemu, niezbędna jest jego dobra diagnoza. 
Tymczasem wiele działań na rzecz upowszechnienia technologii ICT i przeciwdziałania wykluczeniu cyfrowemu jest słabo dostosowanych do rzeczywistych problemów ${ }^{98}$. Dlatego też warto w tym miejscu przyjrzeć się, jakie są przyczyny braku nowych technologii w gospodarstwach domowych.

W pierwszej kolejności przeanalizujmy znaczenie deklarowanego braku możliwości finansowych jako powodu nieposiadania danej technologii. Wykres 4.3.1 w rozdz. 4.3.1 obrazuje dostępność różnych technologii w gospodarstwach domowych. Jak można zaobserwować, w ostatnich latach znacząco poprawia się ich dostępność. Jednocześnie maleje też odsetek gospodarstw domowych, które nie posiadając danego sprzętu, tłumaczą jego brak względami finansowymi (wykres 4.3.3 w rozdz. 4.3.1).

Obecnie 13 proc. wszystkich gospodarstw deklaruje niemożność zakupu komputera stacjonarnego ze względów finansowych, jest to tylko nieznacznie mniej niż w 2009 roku. Ponadto 25 proc. deklaruje chęć posiadania laptopa i brak środków na jego zakup, natomiast cztery lata temu było to 35 proc. Mimo zmniejszania się grupy gospodarstw domowych deklarujących chęć posiadania komputera i brak możliwości finansowych jego zakupu, wciąż stosunkowo często brak komputera tłumaczony jest względami finansowymi. Należy jednak do takich deklaracji podchodzić z dużą ostrożnością, często jest to bowiem wygodne wytłumaczenie, a faktyczne powody są bardziej złożone. Znaczenie zasobności materialnej dla posiadania komputera jest wyraźnie mniejsze niż znaczenie innych czynników. Prawie 46 proc. gospodarstw domowych z najniższego kwartyla dochodów posiada komputer, a 39 dostęp do internetu. Oznacza to, że przynajmniej część z uboższych gospodarstw domowych jest w stanie zdobyć sprzęt ICT.

Zaledwie 12 proc. gospodarstw domowych deklaruje, że chciałoby mieć dostęp do internetu, ale nie może sobie na niego pozwolić ze względów finansowych. Jest to tylko 30 proc. spośród tych, bez dostępu do sieci. Co więcej, podobnie jak w przypadku komputerów gospodarstw takich jest wyraźnie mniej niż w ubiegłych latach. Tym samym 27 proc. wszystkich gospodarstw domowych nie ma dostępu do internetu, ale powody tego stanu rzeczy są niefinansowe. Przyczynom braku dostępu do internetu wart przyjrzeć się nieco bardziej szczegółowo. Deklarowane powody braku sieci zostały przedstawione na wykresie 7.1.6.

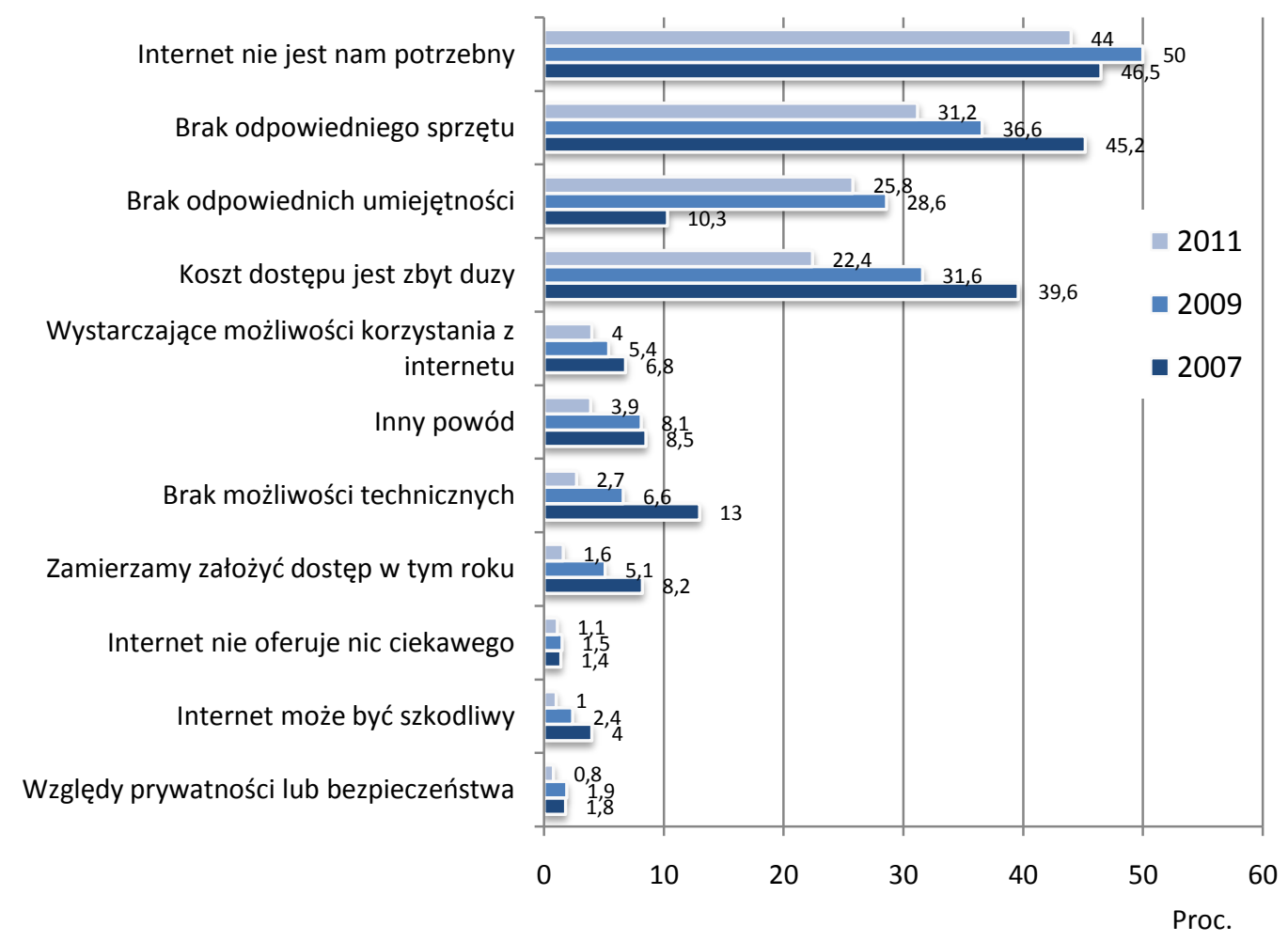

Wykres 7.1.6. Powody braku dostępu do internetu w gospodarstwach domowych w latach 2007-2011.

Najczęściej wymienianym powodem jest brak potrzeby, wskazuje go 44 proc. gospodarstw bez sieci. W drugiej kolejności podawany jest brak odpowiedniego sprzętu (31 proc.). Warto zauważyć, że powód ten jest wymieniany coraz rzadziej i to nawet mimo tego, że zmalała też liczba gospodarstw mających komputer bez dostępu do sieci. Innym czynnikiem, który także jest teraz znacznie rzadziej wymieniany, są wysokie koszty dostępu. Obecnie wymienia je 22 proc. gospodarstw bez internetu, a jeszcze cztery lata temu było to prawie 40 proc. Spadki te mogą być efektem dwóch czynników - malejących cen sprzętu i samego dostępu do sieci, a także tego, że osoby, które wcześniej narzekały na brak sprzętu i wysokie koszty, mimo wszystko miały znacznie wyższe motywacje i dużej

\footnotetext{
${ }^{98}$ Doskonałym przykładem jest tu działanie 8.3 Programu Operacyjnego Innowacyjna Gospodarka.
} 
części z nich ten dostęp udało się już pozyskać. Jako powód braku internetu rzadziej wymieniany jest również brak technicznych możliwości korzystania ze stałego łącza, co jest związane z upowszechnieniem dostępu, a także z łączami mobilnymi. Jedynie około 1 proc. wszystkich gospodarstw domowych w Polsce deklaruje brak możliwości posiadania sieci w domu. To bardzo mało. Pokazuje to również, że problem tzw. białych plam jest mało istotny. Znaczenie ma natomiast jakość tego dostępu - jego niezawodność, a także przepustowość łączy.

Wśród ważnych powodów braku dostępu do sieci wymieniany jest brak umiejętności korzystania. Jako jedną z głównych powodów braku internetu, przyczynę tą wymienia mniej więcej co czwarte gospodarstwo bez dostępu. Inne powody są już zdecydowanie rzadziej wymieniane. Pogłębia się więc trend obserwowany już od kilku lat twarde bariery dostępu do internetu (infrastrukturalne czy finansowe) są coraz mniej znaczące, natomiast coraz większymi barierami upowszechnienia nowych technologii są bariery miękkie - brak wiedzy i uświadamianych potrzeb, a także nieposiadanie odpowiednich umiejętności korzystania. Należy oczekiwać, że tendencja ta będzie się w najbliższych latach pogłębiała.

\subsection{Użytkownicy internetu i osoby niekorzystające}

\subsubsection{Polacy a nowe technologie}

Liczba użytkowników internetu systematycznie rośnie. W pierwszej połowie 2011 roku korzystało z niego już 60 proc. Polaków w wieku 16 i więcej lat. Tempo przyrostu nowych użytkowników internetu wynosi około 9 p.p. w okresie dwóch lat.

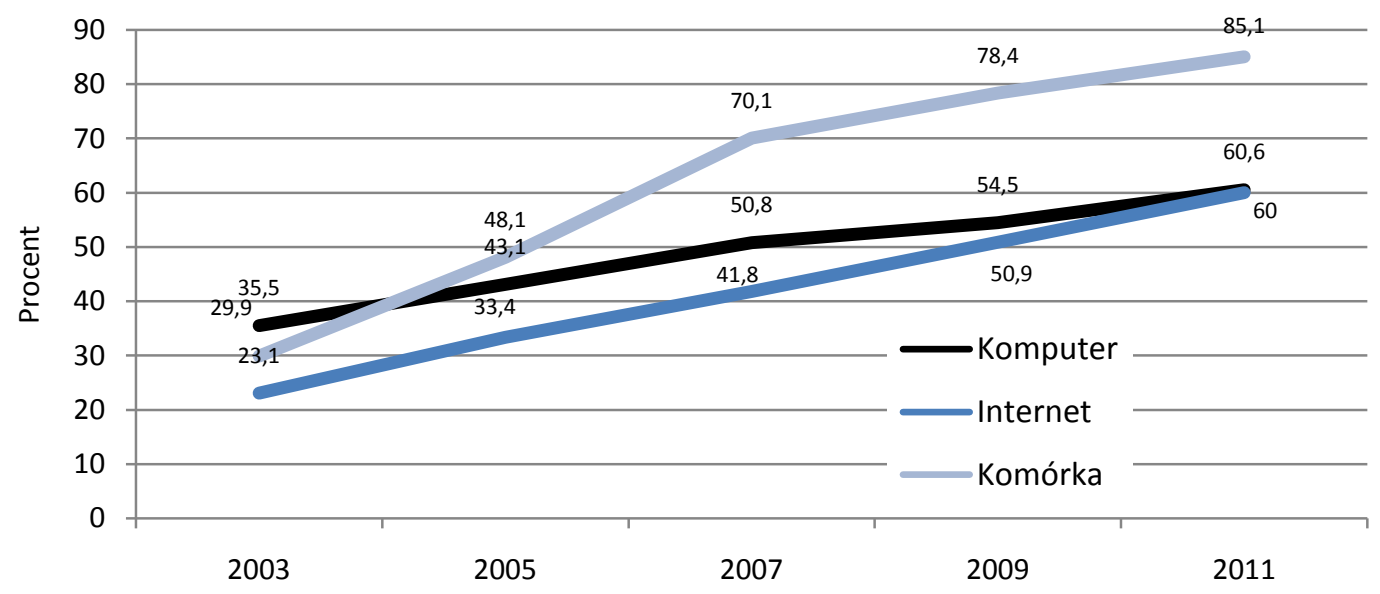

Wykres 7.2.1. Korzystanie z technologii informacyjno-komunikacyjnych $w$ latach 2003-2011.

Z komputera korzysta 60,7 proc. osób w wieku 16 i więcej lat, a więc tylko nieznacznie więcej niż z internetu. Używanie komputera jest praktycznie równoważne korzystaniu także z sieci, choć już dwa lata temu różnica była nieznaczna. Co ciekawe, obecnie pojawiła się też niewielka grupa osób, które z jednej strony deklarują, że nie korzystają z komputerów, ale korzystają z internetu.

Jednocześnie przyrost użytkowników komputerów był w ostatnich latach bardzo powolny. Podobnie, od 2007 roku wolniejszy jest również przyrost osób korzystających z telefonów komórkowych. Z tych ostatnich korzysta już ponad 85 proc. Polaków. Przyrost użytkowników komórek, tak jak w latach poprzednich, jest szybszy niż przyrost osób korzystających z komputerów.

Podobnie jak w poprzednich latach zauważalne było zjawisko zaprzestawania korzystania $\mathrm{z}$ internetu. Faktyczny przyrost nowych użytkowników jest więc większy niż pokazują to zmiany zaprezentowane na wykresie 7.2.1. W okresie dwóch lat, od marca $2009 \mathrm{z}$ internetu przestało korzystać 7 proc. ówczesnych użytkowników. Również w poprzednich dwóch latach przestało używać sieci 7,5 proc. osób korzystających z niej w 2007 roku. Skala zaprzestawania jest obecnie mniejsza niż jeszcze kilka lat temu, przykładowo w okresie 2005-2007 przestało korzystać 13 proc. użytkowników, a w latach 2003-2005 aż ponad 15 proc. Przyczyny rezygnacji najczęściej związane z utratą dostępu ze względu na zmianę sytuacji życiowej, na przykład zmianę lub stratę pracy, ukończenie edukacji, przeprowadzkę lub wyprowadzenie się z gospodarstwa domowego dzieci, które były użytkownikami i posiadaczami komputerów.

Coraz rzadziej zdarza się, że osoby korzystające $\mathrm{z}$ internetu nie mają do niego dostępu w domu (wykres 7.2.2). W 2011 roku 94 proc. osób korzystających z internetu ma dostęp do sieci w domu. Dwa lata temu było to 91 proc. a w 200780 proc. Z drugiej strony rośnie też liczba osób, które nie korzystają z internetu, mimo iż posiadają komputer z dostępem do sieci we własnym domu. W 2009 roku było to 13 proc. dorosłych Polaków, obecnie jest to już ponad 14 proc. Tym samym z domowego dostępu do internetu nie korzysta dokładnie co piąta osoba posiadająca taki dostęp. Tam samo jest z korzystaniem z komputerów -- podobnie jak w 2009 roku nieco ponad 17,3 proc. 
Polaków w wieku 16 i więcej lat to osoby, które mają w domu komputer, a mimo tego w ogóle z niego nie korzystają.

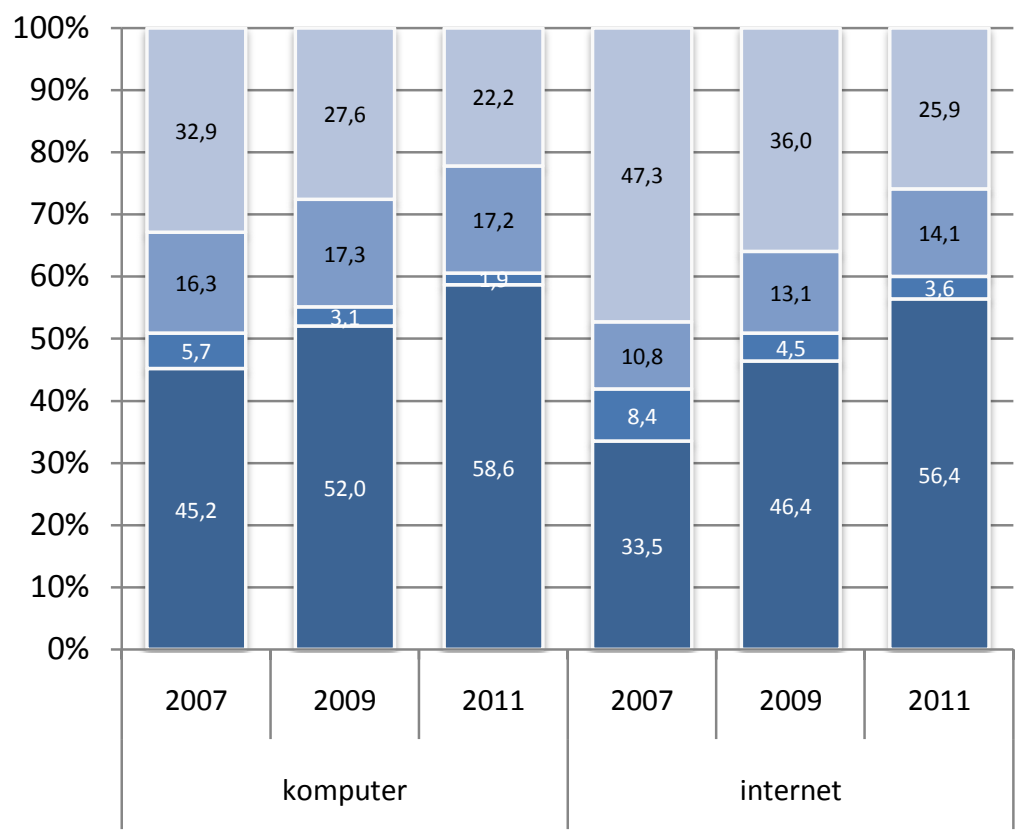

nie posiada i nie korzysta

- posiada w domu, ale nie korzysta

nie posiada w domu, ale korzysta

- posiada w domu i korzysta

Wykres 7.2.2. Korzystanie a posiadanie w gospodarstwach domowych z komputerów i internetu w latach 2007 2011.

Już ponad 35 proc. osób, które nie korzystają z internetu, to ludzie, którzy mają komputer i dostęp do sieci w domu. Wśród nieużywających internetu bardzo szybko rośnie grupa tych, którzy mają dostęp. Jeszcze w 2007 dostęp do sieci miało 18 proc. osób niekorzystających. Wyniki te pokazują, że jednymi z najważniejszych barier w korzystaniu z komputerów i internetu jest brak odpowiedniej motywacji i/lub umiejętności do korzystania z tych technologii. Sam dostęp nie gwarantuje jeszcze, że ludzie będą z niego korzystać. Sprzęt i szerokopasmowa sieć nie wystarczą do tego, by korzystanie z ICT było w Polsce rzeczywiście powszechne.

Aby odpowiedzieć na pytanie, dlaczego nie wszyscy posiadający dostęp korzystają z internetu, warto przeanalizować, kim są te osoby. Wykres 7.2.3 pokazuje dostępność i wykorzystanie internetu w różnych grupach wieku. Jak można zaobserwować - wśród osób mających do 50 lat dostępność internetu w ich domach przekracza 80 proc. Dopiero osoby mające 50 i więcej lat rzadziej mają dostęp do sieci. Wraz z wiekiem maleje wyposażenie w komputer, ale jeszcze szybciej maleje korzystanie $\mathrm{z}$ internetu.

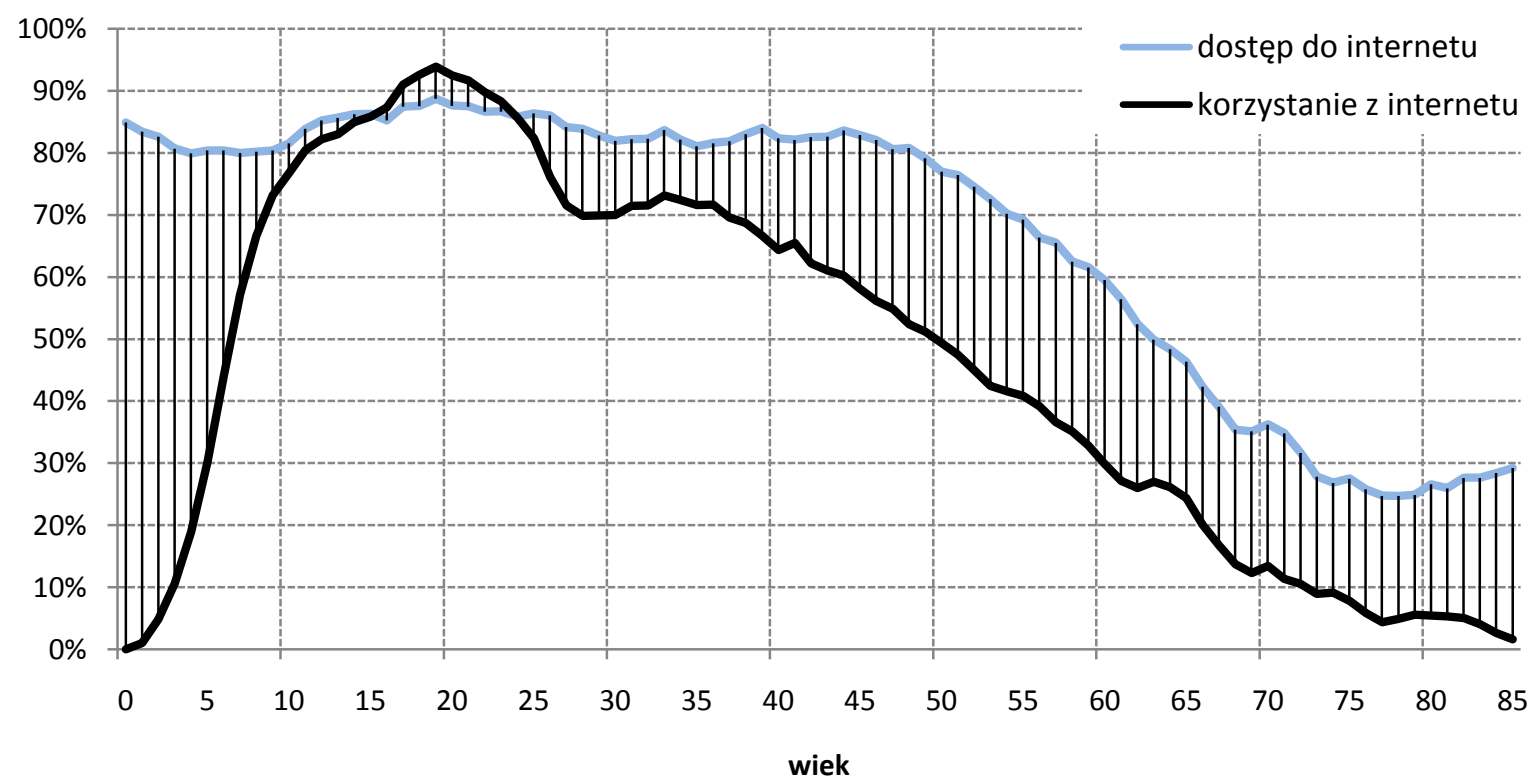

Wykres 7.2.3. Dostęp i korzystanie z internetu wśród osób w różnym wieku 


\subsubsection{Kto korzysta $\mathrm{z}$ internetu?}

Choć przybywa użytkowników internetu, to jednak korzystanie z sieci jest ciągle bardzo zróżnicowane ze względu na szereg czynników społeczno-demograficznych. Warto przeanalizować, od czego zależy korzystanie z nowych technologii; analizy takie mogą być wskazówką do działań podejmowanych na rzecz e-integracji i przeciwdziałania cyfrowemu wykluczeniu. Dodatkowo warto porównać, jak różni się struktura internautów oraz osób niekorzystających ze względu na najważniejsze zmienne społeczno-demograficzne.

Cały czas mężczyźni korzystają z internetu częściej niż kobiety. Wśród osób w wieku 16 i więcej lat internautami jest 62 proc. mężczyzn i 58 proc. kobiet. Różnica nie jest duża i zbliżona do tej sprzed dwóch lat. Co więcej, ze względu na ogólnie większą liczbę kobiet niż mężczyzn w populacji, liczba kobiet korzystających z internetu jest wyższa niż liczba użytkowników płci męskiej. Panie stanowią już ponad 53 proc. wszystkich użytkowników.

Największe różnice pomiędzy osobami korzystającymi z internetu i tymi, którzy z niego nie korzystają, są pod względem wieku i wykształcenia. Z internetu korzysta zdecydowana większość młodych (93 proc. osób w wieku 16-24 lat) i bardzo niewiele starszych osób (11 proc. w wieku 65 i więcej lat) (wykres 7.2.4). Korzystanie z komputerów i internetu $\mathrm{w}$ różnych grupach wieku jest bardzo różne. Jak można zaobserwować na wykresie, z sieci korzystają prawie wszyscy ludzie młodzi. Również wśród osób w wieku 25-34 lat korzysta zdecydowana większość. Natomiast osoby będące w wieku emerytalnym korzystają bardzo rzadko. Różnice w wykorzystaniu internetu ze względu na wiek są bardzo silne i nic nie wskazuje na to, aby miały się zmniejszać. Cały czas to w młodszych grupach wieku jest szybszy przyrost nowych użytkowników.

Jak łatwo się domyślić, wśród osób korzystających z internetu jest zdecydowanie więcej ludzi młodych, natomiast wśród niekorzystających dominują osoby starsze (wykres 7.2.5). Obecnie 43 proc. internautów to osoby mające 16-34 lat. Wśród niekorzystających osoby w tym wieku stanowią niecałe 7 proc. Tymczasem osoby w wieku 45 i więcej lat, choć stanowią już 35 proc. użytkowników, to w grupie niekorzystających stanowią aż 84 proc. W coraz większym stopniu w grupie tych, którzy z sieci jeszcze nie korzystają, pozostają osoby starsze, ponad połowa przekroczyła już 60-ty rok życia. Z drugiej strony, w zbiorowości internautów przeciętny wiek użytkownika jest także coraz wyższy. Wpływ ma na to również mniejsza liczebność młodszych roczników. Jeszcze dwa lata temu osoby w wieku 16-24 lat stanowiły 28 proc. korzystających, a obecnie już tylko 19 proc.

Tak duże międzypokoleniowe różnice w korzystaniu z internetu mogą powodować wiele negatywnych zjawisk społecznych. Szybkie zwiększenie znaczenia internetu w różnych dziedzinach życia sprawia, że osoby, które z niego nie korzystają, mają coraz bardziej utrudnione możliwości funkcjonowania w tych sferach. Dotyczy to zarówno sytuacji zawodowej, jak również uczestnictwa w życiu społecznym i kulturalnym (por. Batorski, Zając 2010). Coraz częściej informacje o możliwości zatrudnienia są dostępne wyłącznie w internecie. W coraz większym też stopniu informacje o wydarzeniach kulturalnych, łatwe do znalezienia w sieci, są słabiej dostępne poza internetem. Sieć staje się bramą do aktywności w codziennym życiu. Dodatkowe problemy są związane z rosnącymi barierami w porozumiewaniu się osób z różnych pokoleń. Światy, w których funkcjonują młodsi-internauci i starsi-nieinternauci, w coraz większym stopniu się od siebie różnią.

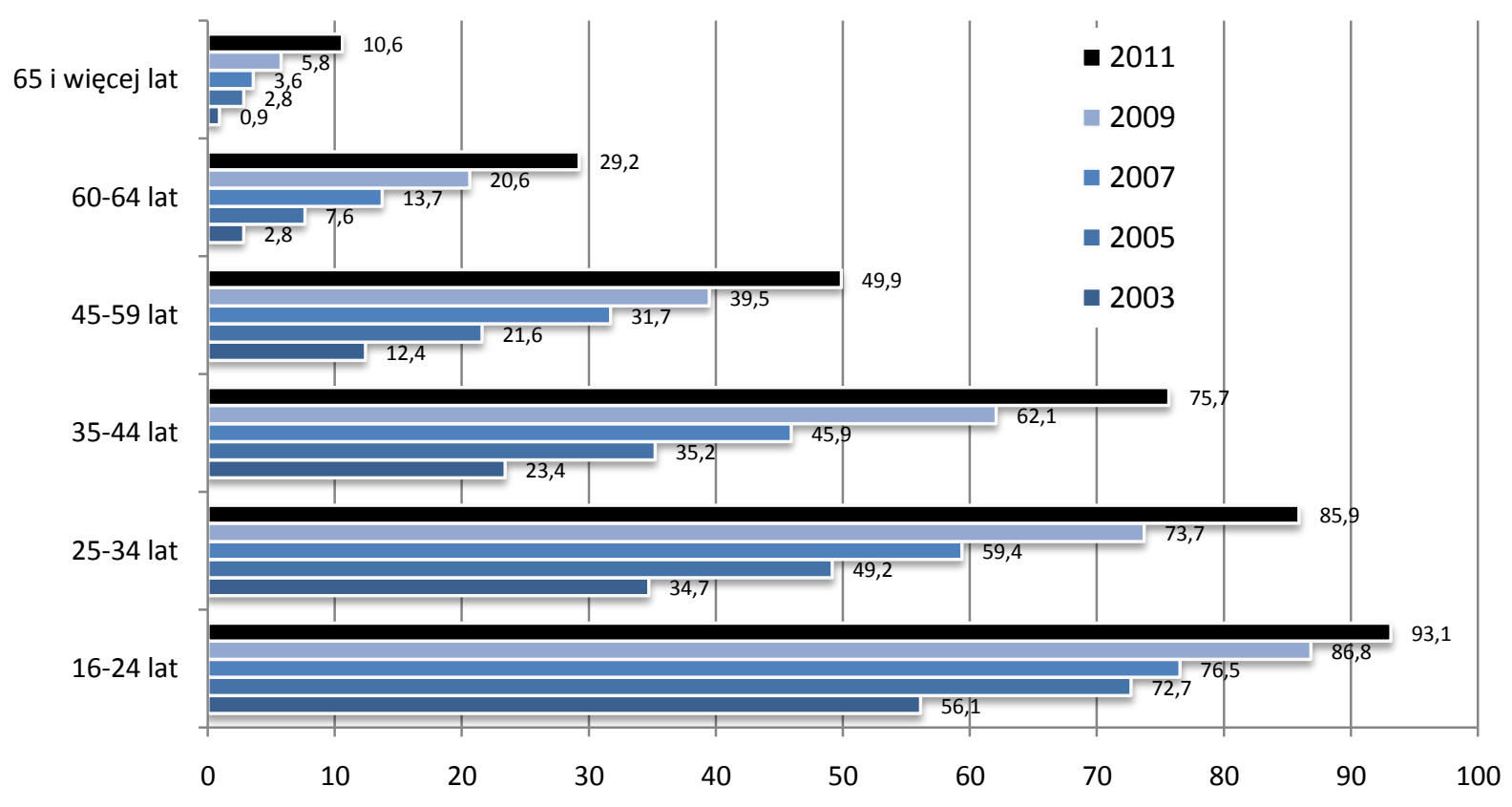

Wykres 7.2.4. Procent korzystajacych z internetu $w$ różnych grupach wieku $w$ latach 2003-2011 


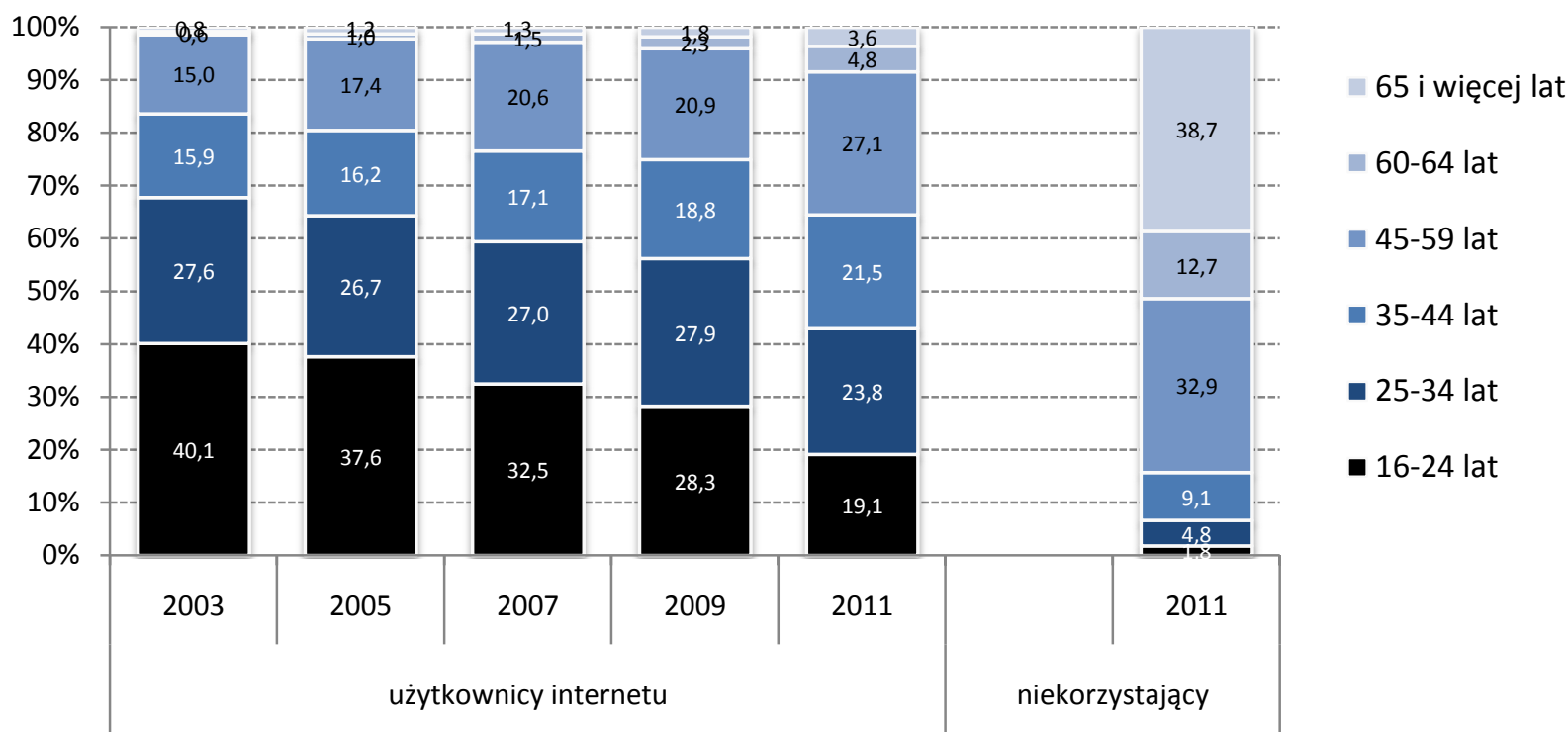

Wykres 7.2.5. Zmiana struktury wieku internautów w latach 2003-2011 oraz osoby niekorzystajace z internetu w 2011 roku

Drugim czynnikiem o bardzo dużym znaczeniu dla korzystania z internetu jest wykształcenie. Różnice w korzystaniu z internetu $\mathrm{w}$ zależności od wykształcenia są kolosalne. Z sieci korzystają prawie wszystkie osoby uczące się ( 97 proc. uczniów i studentów) i lepiej wykształcone (89 proc. osób z wyższym wykształceniem). Tymczasem, wśród osób z wykształceniem podstawowym jest dokładnie odwrotnie - z sieci korzysta zaledwie 10 proc. Wyższe wykształcenie posiada aż 32 proc. internautów i tylko 6 proc. niekorzystających. Zaledwie 3 proc. internautów to osoby z wykształceniem podstawowym, wśród niekorzystających takich osób jest ponad 34 proc., jeszcze większą grupę wśród niekorzystających stanowią osoby z wykształceniem zawodowym.

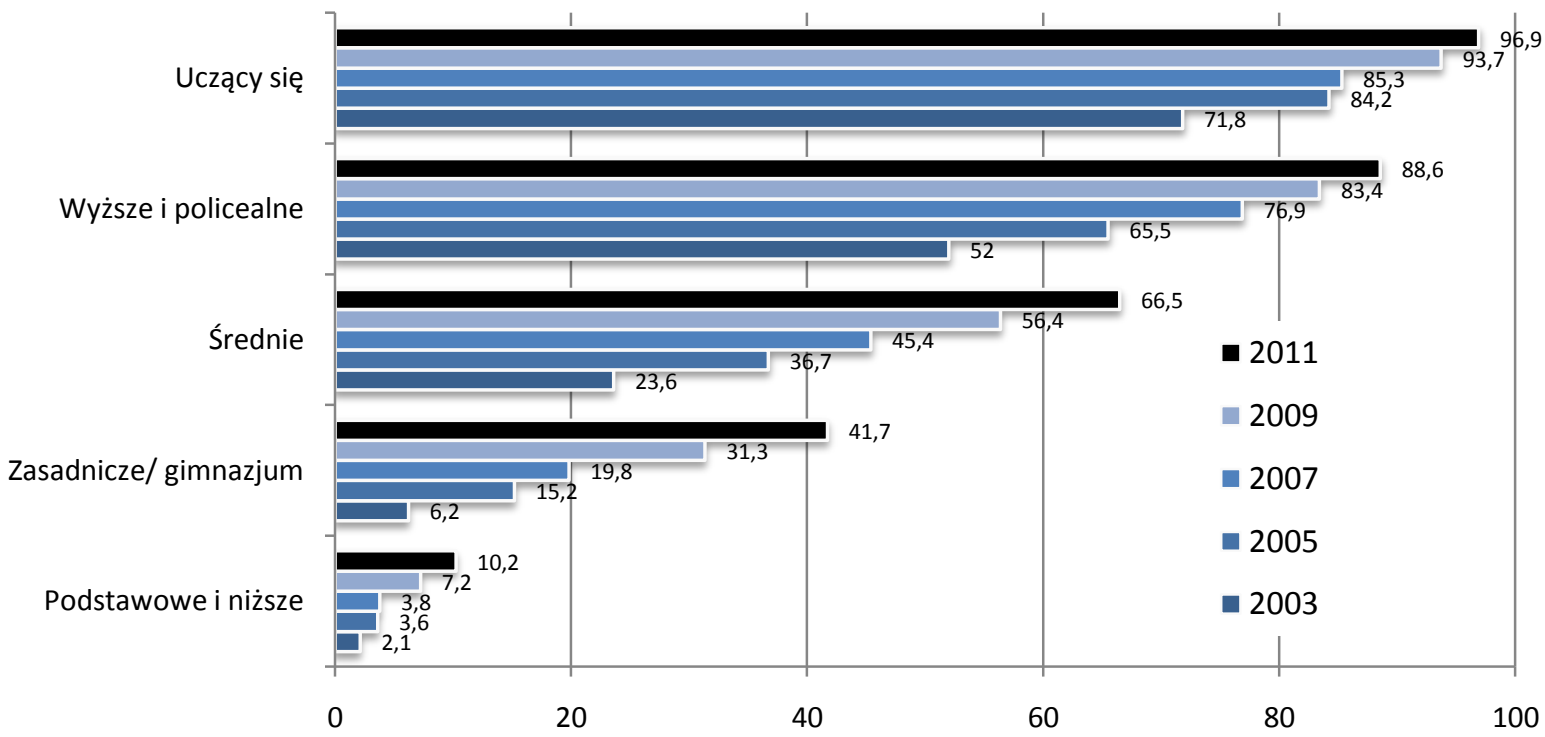

Wykres 7.2.6. Procent korzystajacych z internetu w różnych grupach ze względu na wyksztatcenie w latach 20032011

Znaczenie wykształcenia i wieku dla korzystania z telefonów komórkowych jest już znacznie mniejsze niż dla używania komputerów i internetu, choć różnice pomiędzy grupami najczęściej i najrzadziej korzystającymi są prawie dwukrotne. Mniejsza skala obserwowanych różnic jest efektem szybszego upowszechnienia się telefonów komórkowych (por. wykres 7.2.1).

Korzystanie z komputerów i internetu jest też istotnie związane z zamożnością, jednak zależność ta jest mniejsza niż w przypadku wieku czy wykształcenia. Wśród jednej czwartej Polaków o najwyższych dochodach z internetu korzysta 81 proc., natomiast w grupie o najniższych dochodach zaledwie 42 proc. Mniejsze różnice są 
natomiast związane z posiadaniem telefonu komórkowego - ma go 76 proc. osób o niskich dochodach i 94 proc. z grupy o najwyższych dochodach.

Tabela 7.2.1. Korzystanie z nowych technologii w różnych grupach

\begin{tabular}{|c|c|c|c|c|c|c|}
\hline & Grupa & komputer & internet & komórka & Niekorzystający & $\begin{array}{c}\text { Korzystający ze } \\
\text { wszystkich }\end{array}$ \\
\hline Ogółem & & 60,6 & 60,0 & 85,1 & 13,3 & 55,0 \\
\hline \multirow{2}{*}{ Płeć } & Mężczyźni & 62,3 & 62,0 & 87,1 & 11,1 & 56,6 \\
\hline & Kobiety & 59,1 & 58,1 & 83,2 & 15,2 & 53,5 \\
\hline \multirow{6}{*}{ Wiek } & 16-24 lat & 93,2 & 93,1 & 97,2 & 0,5 & 86,6 \\
\hline & $25-34$ lat & 86,4 & 85,9 & 97,8 & 1,4 & 81,1 \\
\hline & $35-44$ lat & 75,8 & 75,7 & 96,4 & 2,5 & 70,0 \\
\hline & 45-59 lat & 50,8 & 49,9 & 86,2 & 11,1 & 43,9 \\
\hline & $60-64$ lat & 30,3 & 29,2 & 76,0 & 22,2 & 25,2 \\
\hline & 65 i więcej lat & 11,4 & 10,6 & 48,7 & 50,1 & 8,9 \\
\hline \multirow{9}{*}{$\begin{array}{l}\text { Status społeczno- } \\
\text { zawodowy }\end{array}$} & Prac. Sektora publicznego & 84,1 & 83,0 & 96,5 & 1,5 & 78,5 \\
\hline & Prac. Sektora prywatnego & 75,3 & 74,8 & 96,6 & 2,1 & 69,0 \\
\hline & Prywatni przedsiębiorcy & 83,1 & 85,2 & 97,3 & 1,5 & 79,1 \\
\hline & Rolnicy & 37,6 & 33,0 & 79,8 & 17,6 & 28,9 \\
\hline & Renciści & 23,0 & 21,6 & 66,5 & 32,0 & 19,0 \\
\hline & Emeryci & 20,5 & 19,7 & 60,1 & 38,4 & 16,6 \\
\hline & Uczniowie i studenci & 96,4 & 96,9 & 97,7 & 0,2 & 90,9 \\
\hline & Bezrobotni & 62,3 & 63,2 & 90,5 & 8,6 & 57,3 \\
\hline & Inni bierni zawodowo & 55,9 & 55,3 & 83,4 & 13,4 & 48,5 \\
\hline \multirow{5}{*}{$\begin{array}{l}\text { Wykształcenie z } \\
\text { wyodrębnieniem } \\
\text { osób uczących się }\end{array}$} & Podstawowe i niższe & 11,0 & 10,2 & 51,3 & 47,2 & 7,8 \\
\hline & Zasadnicze/ gimnazjum & 42,4 & 41,7 & 84,3 & 14,1 & 35,7 \\
\hline & Średnie & 67,3 & 66,5 & 90,6 & 7,7 & 60,8 \\
\hline & Wyższe i policealne & 88,8 & 88,6 & 95,8 & 2,4 & 84,6 \\
\hline & Uczący się & 96,4 & 96,9 & 97,7 & 0,2 & 90,9 \\
\hline \multirow{6}{*}{$\begin{array}{l}\text { Wielkość } \\
\text { miejscowości } \\
\text { zamieszkania }\end{array}$} & Miasta powyżej 500 tys. & 77,2 & 76,7 & 93,6 & 5,6 & 73,2 \\
\hline & Miasta $200-500$ tys. & 71,7 & 72,2 & 89,2 & 8,6 & 66,0 \\
\hline & Miasta $100-200$ tys. & 66,5 & 66,1 & 86,3 & 11,1 & 60,6 \\
\hline & Miasta 20-100 tys. & 63,9 & 64,2 & 88,6 & 10,0 & 58,8 \\
\hline & Miasta poniżej 20 tys. & 60,0 & 59,5 & 86,4 & 12,3 & 54,8 \\
\hline & Wieś & 49,6 & 48,0 & 78,6 & 19,4 & 43,2 \\
\hline \multirow{4}{*}{$\begin{array}{l}\text { Dochody na } \\
\text { osobę w } \\
\text { gospodarstwie } \\
\text { domowym }\end{array}$} & Pierwszy kwartyl & 43,0 & 41,6 & 76,2 & 21,6 & 36,4 \\
\hline & Drugi kwartyl & 55,7 & 54,7 & 83,1 & 15,4 & 50,0 \\
\hline & Trzeci kwartyl & 60,9 & 60,1 & 85,8 & 12,5 & 55,2 \\
\hline & Czwarty kwartyl & 80,7 & 80,8 & 94,3 & 4,6 & 76,6 \\
\hline
\end{tabular}

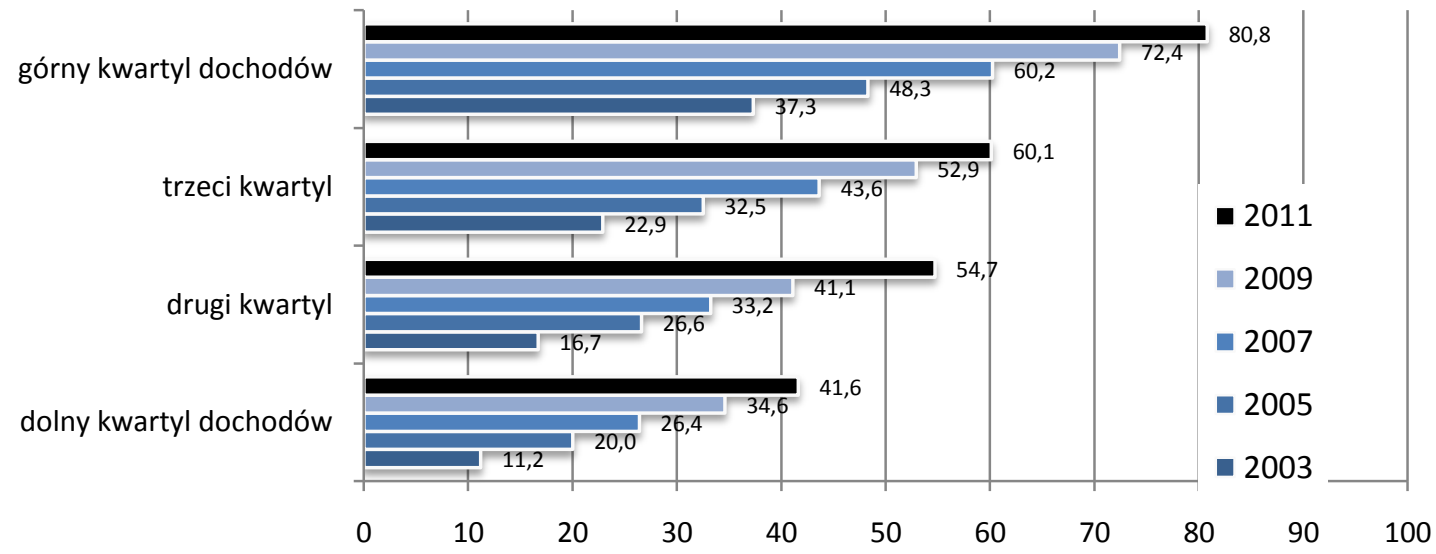

Wykres 7.2.7. Dochody a procent korzystajacych z internetu w latach 2003-2011

Istotne znaczenie dla faktu korzystania z komputerów i internetu ma także status społeczno-zawodowy. Jak wspomnieliśmy wcześniej, sieci używaja prawie wszyscy uczniowie i studenci (97 proc.), a także większość osób pracujących. W tej ostatniej grupie nieco rzadziej korzystają pracujący w sektorze prywatnym (75 proc.). W ostatnich dwóch latach znacząco wzrósł odsetek użytkowników wśród osób bezrobotnych, a także biernych zawodowo. Najmniej użytkowników jest wśród emerytów i rencistów. Rośnie liczba rolników korzystających z internetu (wykres 7.2.5). Obecnie 55proc. internautów w wieku 16 i więcej lat, to osoby pracujące (poza rolnictwem), kolejne 15proc. stanowią uczniowie i studenci. Z kolei emeryci to ledwie 9 proc. korzystających i aż 44proc. niekorzystających. 


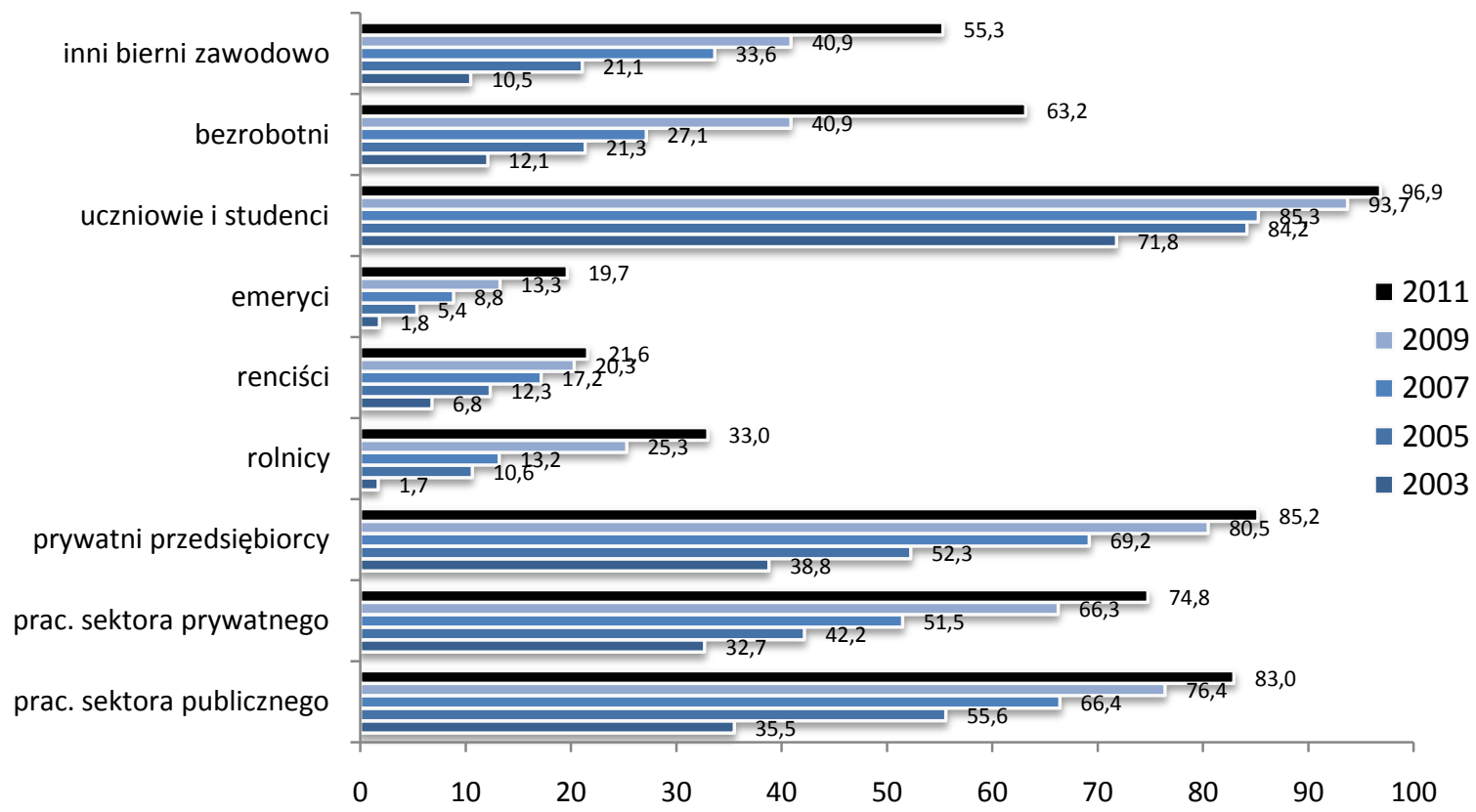

Wykres 7.2.8. Procent korzystajacych z internetu $w$ różnych grupach ze względu na status społeczno-zawodowy $w$ latach 2003-2011

Korzystanie $\mathrm{z}$ internetu jest też zróżnicowane ze względu na wielkość miejscowości zamieszkania. W większych miejscowościach korzysta wyraźnie więcej osób niż na wsi i w małych miasteczkach. W największych miastach internetu używa ponad trzy czwarte mieszkańców, natomiast na wsi prawie połowa. Warto podkreślić, że różnice ze względu na wielkość miejscowości zamieszkania są obecnie znacznie mniejsze niż jeszcze w 2007 roku. Przyrost liczby użytkowników na wsi od tamtego czasu wyniósł ponad 22 p.p. Niestety udział mieszkańców terenów wiejskich wśród tych, którzy z sieci nie korzystaja, jest coraz większy i wynosi już prawie 50 proc.

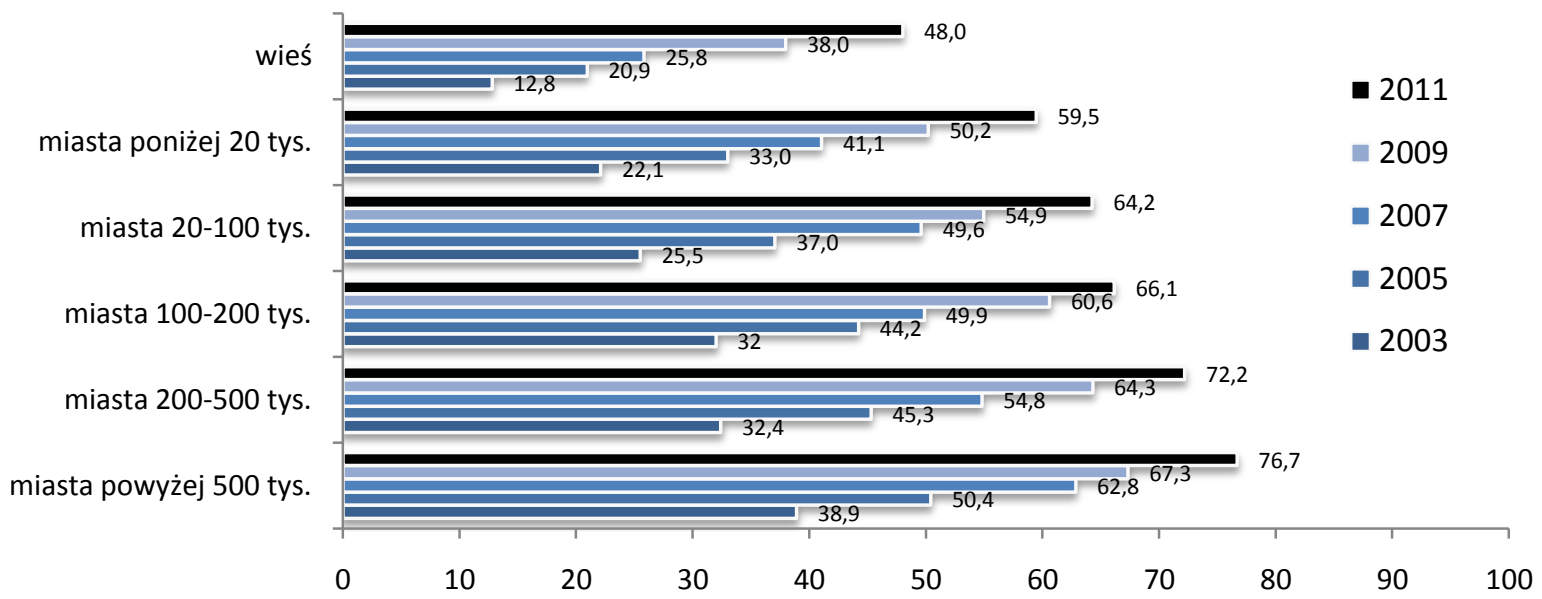

Wykres 7.2.9. Korzystanie z internetu w różnych grupach ze względu na wielkość miejscowości zamieszkania w latach 2003-2011

Dla korzystania z internetu znaczenie ma nie tylko wielkość miejscowości zamieszkania, ale również region. Rzadziej korzystają osoby mieszkające w województwach ściany wschodniej. Wykres 7.2 .7 szczegółowo pokazuje korzystanie z internetu w poszczególnych województwach oraz zmiany, jakie zaszły w latach 2007-2011. 


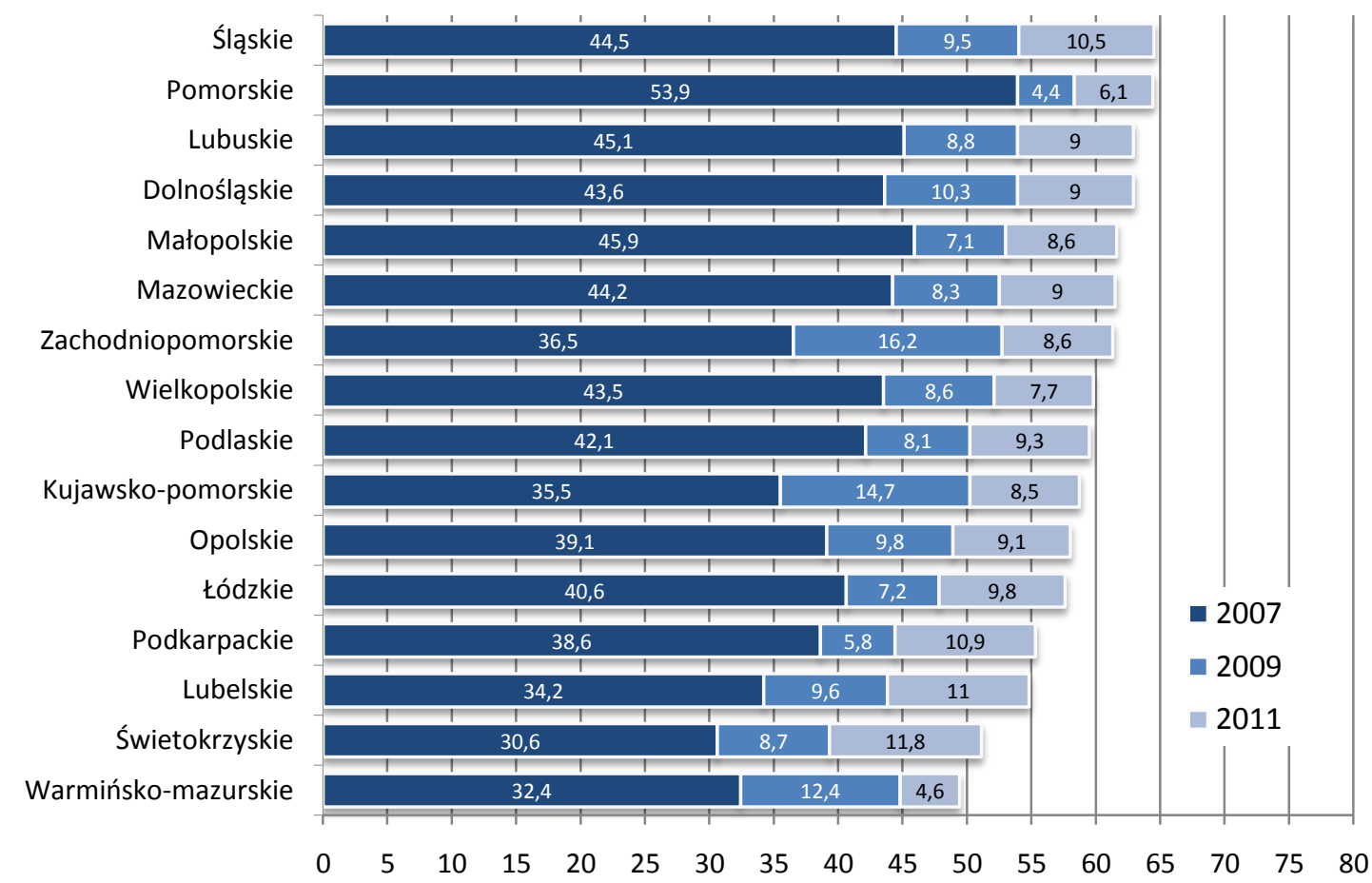

Wykres 7.2.10. Procent osób $w$ wieku 16+ lat korzystajacych z internetu w poszczególnych województwach w2007 r.

i procent nowych osób korzystajacych latach 2009 i 2011

Chociaż bardzo silna jest zależność między dostępem do internetu i korzystaniem z niego, nie zawsze większa dostępność przekłada się na większą liczbę osób korzystających. Szczególnie w województwach warmińskomazurskim, małopolskim i wielkopolskim użytkowników jest mało jak na liczbę gospodarstw domowych posiadających dostęp. W efekcie najwięcej użytkowników jest obecnie w województwach śląskim i pomorskim, a tylko nieznacznie mniej w lubuskim i dolnośląskim. Zdecydowanie najrzadziej korzystają z internetu mieszkańcy województwa warmińsko-mazurskiego i świętokrzyskiego.

\subsubsection{Korzystanie z różnych technologii}

Upowszechnienie technologii informacyjno-komunikacyjnych w polskim społeczeństwie ma dość charakterystyczny wzorzec. Analiza współkorzystania z różnych technologii na poniższym wykresie pokazuje znaczący przyrost liczby osób korzystających z komputerów, internetu i telefonów komórkowych. Osób, które korzystają zarówno z komputerów i internetu, jak i z telefonów komórkowych, jest obecnie 55 proc. (wykres 7.2.11). Natomiast takich, które nie korzystają z żadnej z tych technologii jest nieco ponad 13 proc. W stosunku do lat ubiegłych obserwujemy szybki przyrost osób korzystających i kurczenie się grupy osób, które żadnej z tych technologii nie używają.

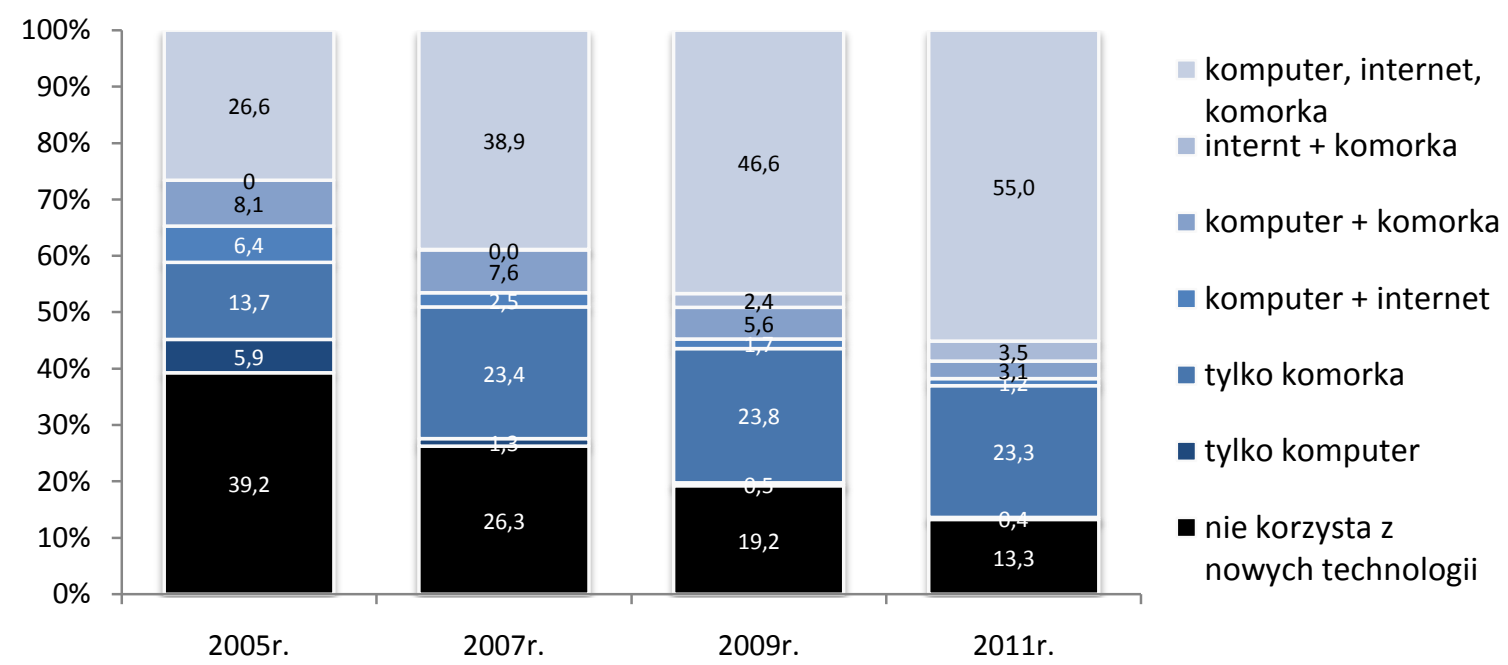

Wykres 7.2.11. Procent korzystających z różnych technologii w latach 2005-2011. 
Grupa osób korzystających ze wszystkich tych technologii powiększa się przede wszystkim dzięki rozpoczynaniu używania komputerów i sieci przez osoby, które wcześniej korzystały wyłącznie z mobilnej telefonii. Bezpośrednie przejścia z grupy osób niekorzystających z żadnej analizowanych technologii do grupy korzystającej ze wszystkich trzech są niezmiernie rzadkie. Jednocześnie od 2007 roku udział osób, które korzystają wyłącznie z telefonów komórkowych, praktycznie się nie zmienia. Do grupy tej należy około 23 proc. Polaków w wieku 16 i więcej lat, z tym, że z roku na rok skład tej grupy mocno się zmienia. Część osób zaczyna korzystać z pozostałych technologii, a osoby, które dotychczas nie korzystały, zaczynają używać komórek.

Korzystanie z komputera prawie zawsze oznacza również korzystanie z telefonów komórkowych i internetu. Osób, które korzystają wyłącznie z komputerów, jest mniej niż pół procenta. Korzystających z komputerów i sieci, ale nie z komórek zaledwie 1,2 proc. Niewielka jest też grupa osób, które choć korzystając z innych technologii, nie używają internetu (lub robią to w bardzo ograniczonym zakresie). W 2005 roku było ich 8 proc., a obecnie ledwie 3 proc.

Zróżnicowanie grup społeczno-demograficznych pod względem korzystania z technologii ICT najlepiej można zaobserwować poprzez porównanie tych, którzy korzystają ze wszystkich, z tymi, którzy nie korzystają ani z telefonów komórkowych, ani z komputerów i internetu (tabela 7.2.1). Wśród osób do 34 roku życia ponad 80 proc. korzysta ze wszystkich tych trzech technologii, wśród najstarszej badanej grupy takich osób jest niespełna 9 proc., natomiast połowa nie korzysta z żadnej z tych technologii. Mimo tak znaczących różnic sytuacja i tak się poprawia - dwa lata temu z technologii ICT nie korzystało aż dwie trzecie osób mających 65 i więcej lat. Bardzo duże różnice występują również ze względu na wykształcenie - wszystkich tych narzędzi używa 91 proc. osób uczących się oraz 85 proc. $z$ wyższym wykształceniem i zaledwie niecałe 8 proc. z wykształceniem podstawowym, wśród których prawie 47 proc. w ogóle $\mathrm{z}$ tych technologii nie korzysta.

Najciekawsze różnice związane są jednak ze statusem społeczno-zawodowym. Wśród osób pracujących praktycznie nie zdarzają się osoby niekorzystające, za to prawie 80 proc. przedsiębiorców i pracujących w sektorze publicznym oraz prawie 70 proc. w sektorze prywatnym korzysta ze wszystkich trzech technologii. Osoby, które nie korzystają z ICT, to praktycznie wyłącznie emeryci i renciści, a także kilkanaście procent rolników i osób biernych zawodowo. W pozostałych grupach praktycznie nie ma osób, które nie korzystałyby z komórek lub komputerów. Również dochody i wielkość miejscowości zamieszkania mają istotne znaczenie. Wśród osób z gospodarstw o wyższych dochodach i z większych miast, więcej jest osób korzystających z technologii ICT, a mniej takich, które żadnej z nich nie używają.

\subsubsection{Zmiany $\mathrm{w}$ powszechności korzystania $\mathrm{z}$ internetu}

W poprzednich częściach pokazane zostało korzystanie $\mathrm{z}$ internetu i innych technologii informacyjnokomunikacyjnych w różnych grupach społeczno-demograficznych, a także to, jak postępuje proces upowszechniania korzystania w tych różnych grupach. Warto sobie uświadomić, że szybki przyrost użytkowników, jaki miał miejsce w ostatnich latach, powoduje również zmianę struktury populacji internautów. Zmiany te mają daleko idące konsekwencje. Doskonałym przykładem są treści i usługi dostępne w internecie. Wraz ze zmianami populacji użytkowników, na przykład podnoszeniem się przeciętnego wieku, zmienia się też to, co i jak warto w sieci oferować. Zmianę struktury osób korzystających z internetu w latach 2003-2011 przedstawia tabela 7.2.2.

Największe zmiany w populacji użytkowników internetu związane są z wiekiem. W 2003 roku ponad 40 proc. użytkowników było w wieku 16-24 lat. Obecnie osoby z tej grupy wieku stanowią niecałe 20 proc. internautów. Rośnie przede wszystkim udział osób w wieku 45-59 lat. Przeciętny wiek użytkownika znacząco się w ostatnich latach zwiększył.

Obserwujemy również inne zmiany. Coraz mniej jest wśród internautów osób uczących się. W ciągu kliku lat ich odsetek zmalał z 30 proc. do niecałych 15. Zmiana ta odbywa się przede wszystkim za sprawą zwiększenia udziału emerytów i osób biernych zawodowo oraz niżu demograficznego w grupie uczniów i studentów. Odsetek internautów, którzy pracują niewiele się zmienia. Podobnie jest w przypadku wyższego wykształcenia, które w ostatniej dekadzie posiada nieco ponad 30 proc. użytkowników. Tylko nieznacznie wzrósł udział osób z wykształceniem średnim, a najszybciej zwiększa się grupa osób z wykształceniem zawodowym.

Populacja internautów zmienia się także pod względem wielkości miejsca zamieszkania. Coraz mniejszą część korzystających z sieci stanowią osoby mieszkające w największych miastach. Rośnie udział mieszkańców wsi. W ostatnich ośmiu latach zwiększył się on z 21 do 31 proc. Udział osób z miast mających do 100 tys. mieszkańców niewiele się zmienił.

Dla porównania, ostatnia kolumna tabeli 7.2.2 zawiera dane dotyczące obecnej struktury zbiorowości osób, które $\mathrm{z}$ internetu nie korzystają. 
Tabela 7.2.2. Zmiana struktury populacji internautów w latach 2003-2011.

\begin{tabular}{|c|c|c|c|c|c|c|}
\hline & \multicolumn{5}{|c|}{ Skład populacji internautów w danym roku } & \multirow{2}{*}{$\begin{array}{r}\text { Osoby niekorzystające } \\
\text { z internetu w 2011r. }\end{array}$} \\
\hline & 2003 & 2005 & 2007 & 2009 & 2011 & \\
\hline mężczyzna & 49,9 & 50,4 & 46,3 & 49,4 & 46,8 & 43,6 \\
\hline \multirow[t]{2}{*}{ kobieta } & 50,1 & 49,6 & 53,7 & 50,6 & 53,2 & 56,4 \\
\hline & 2003 & 2005 & 2007 & 2009 & 2011 & Niekorzystający \\
\hline 16-24 lat & 40,1 & 37,6 & 32,5 & 28,3 & 19,1 & 1,8 \\
\hline 25-34 lat & 27,6 & 26,7 & 27,0 & 27,9 & 23,8 & 4,8 \\
\hline 35-44 lat & 15,9 & 16,2 & 17,1 & 18,8 & 21,5 & 9,1 \\
\hline 45-59 lat & 15,0 & 17,4 & 20,6 & 20,9 & 27,1 & 32,9 \\
\hline $60-64$ lat & 0,6 & 1,0 & 1,5 & 2,3 & 4,8 & 12,7 \\
\hline \multirow[t]{2}{*}{65 i więcej lat } & 0,8 & 1,2 & 1,3 & 1,8 & 3,6 & 38,7 \\
\hline & 2003 & 2005 & 2007 & 2009 & 2011 & Niekorzystający \\
\hline prac. sektora publicznego & 24,2 & 24,0 & 23,2 & 20,2 & 19,4 & 5,1 \\
\hline prac. sektora prywatnego & 24,3 & 23,6 & 28,5 & 30,2 & 29,7 & 14,2 \\
\hline prywatni przedsiębiorcy & 7,2 & 6,6 & 7,2 & 6,6 & 6,0 & 1,3 \\
\hline rolnicy & 0,4 & 1,7 & 1,6 & 2,1 & 2,8 & 6,8 \\
\hline renciści & 3,2 & 3,3 & 3,2 & 3,1 & 3,0 & 14,1 \\
\hline emeryci & 1,5 & 2,9 & 4,3 & 5,4 & 9,1 & 43,7 \\
\hline uczniowie i studenci & 30,0 & 26,0 & 21,9 & 19,7 & 14,7 & 0,5 \\
\hline bezrobotni & 6,2 & 6,2 & 4,5 & 4,8 & 6,8 & 5,2 \\
\hline \multirow[t]{2}{*}{ inni bierni zawodowo } & 2,9 & 5,8 & 5,5 & 7,9 & 8,4 & 9,0 \\
\hline & 2003 & 2005 & 2007 & 2009 & 2011 & Niekorzystający \\
\hline Podstawowe i niższe & 2,0 & 2,0 & 1,5 & 2,3 & 2,9 & 34,3 \\
\hline Zasadnicze/ gimnazjum & 7,5 & 12,0 & 12,1 & 16,4 & 19,2 & 37,0 \\
\hline Średnie & 27,7 & 29,1 & 30,0 & 30,1 & 31,8 & 21,9 \\
\hline Wyższe i policealne & 32,9 & 31,7 & 34,4 & 31,4 & 31,5 & 6,2 \\
\hline \multirow[t]{2}{*}{ Uczący się } & 29,9 & 25,3 & 21,9 & 19,7 & 14,5 & 0,5 \\
\hline & 2003 & 2005 & 2007 & 2009 & 2011 & Niekorzystający \\
\hline miasta powyżej 500 tys. & 19,6 & 15,3 & 16,1 & 16,2 & 15,6 & 7,5 \\
\hline miasta $200-500$ tys. & 14,3 & 13,6 & 14,5 & 14,1 & 11,6 & 7,0 \\
\hline miasta $100-200$ tys. & 10,9 & 11,1 & 10,5 & 8,4 & 8,5 & 6,0 \\
\hline miasta $20-100$ tys. & 21,3 & 22,4 & 23,5 & 20,7 & 21,1 & 17,1 \\
\hline miasta poniżej 20 tys. & 12,8 & 14,4 & 12,6 & 12,8 & 11,9 & 12,9 \\
\hline wieś & 21,1 & 23,3 & 22,8 & 27,9 & 31,4 & 49,5 \\
\hline
\end{tabular}




\subsection{Umiejętności i sposoby korzystania z komputerów i internetu}

\subsubsection{Umiejętności korzystania z komputerów}

Umiejętności obsługi komputerów posiadane przez użytkowników są bardzo różne (wykres 7.3.1). Zdecydowanie najwięcej użytkowników posiada kompetencje związane z podstawowym korzystaniem z internetu. Prawie 96 proc. korzysta z poczty elektronicznej, choć dla części z nich bardziej skomplikowane zastosowania, nawet takie jak wysłanie maila z załącznikiem są trudne. Zdecydowana większość użytkowników umie korzystać z przeglądarki internetowej, a 92 proc. deklaruje umiejętność posługiwania się wyszukiwarką.

Umiejętności obsługi komputera są wyraźnie mniej powszechne. Niecałe 70 proc. użytkowników potrafi wykonać podstawowe czynności związane z organizacją systemu plików, takie jak kopiowanie, czy przenoszenie pliku lub folderu. Do umiejętności zainstalowania drukarki, modemu, skanera bądź innych urządzeń przyznaje się 37 proc. użytkowników.

Znajomość programów biurowych jest niewielka. Proste umiejętności związane z obsługą edytora tekstu (umiejętności kopiowania i wklejania fragmentów tekstów) posiada tylko 63 proc. użytkowników. Korzystać z arkusza kalkulacyjnego potrafi ledwie 36 proc. użytkowników komputerów, a przygotować elektroniczna prezentację 23 proc. Odsetki te są niższe niż jeszcze dwa lata temu. Wynika to z przyrostu liczby użytkowników i niskich kompetencji osób zaczynających swoją przygodę z komputerem i internetem. Ogólnie, poziom umiejętności korzystania z komputerów jest wśród obecnych użytkowników podobny do poziomu, jaki był w poprzednich latach. Mimo nieco rzadszego posiadania przez użytkowników umiejętności związanych z samą obsługą komputera i rzadszym korzystaniem z pakietów biurowych, nieco większe są umiejętności związane z korzystaniem z internetu.

Odsetek użytkowników posiadających duże umiejętności korzystania zmienia się bardzo nieznacznie. Około 40 proc. korzystających wymienia przynajmniej dwie trzecie $\mathrm{z}$ badanych przez nas umiejętności. Wszystkie lub prawie wszystkie 12 proc. Wzrost umiejętności korzystania z komputerów w Polskim społeczeństwie wynika przede wszystkim ze wzrostu liczby użytkowników.

Umiejętności korzystania z komputerów są w Polsce niskie. Obecnie zaledwie 9,2 proc. Polaków w wieku 16+ posiada umiejętności obsługi podstawowych programów biurowych i korzystania z internetu. Wynik ten jest i tak poprawą w stosunku do roku 2009, kiedy odsetek ten wynosił 7,5.

kopiowanie lub przenoszenie pliku albo folderu

używanie polecenia kopiowania, wycinania i wklejania w celu powielenia lub przemieszczenia wybranych...

wykorzystanie podstawowych funkcji matematycznych w arkuszu kalkulacyjnym

tworzenie elektronicznej prezentacji

instalowanie nowych urządzeń (np. drukarki, modemu, skanera)

używanie wyszukiwarki internetowej (np. Google, Yahoo!) w celu znalezienia informacji

pisanie programu komputerowego z użyciem języka programowania

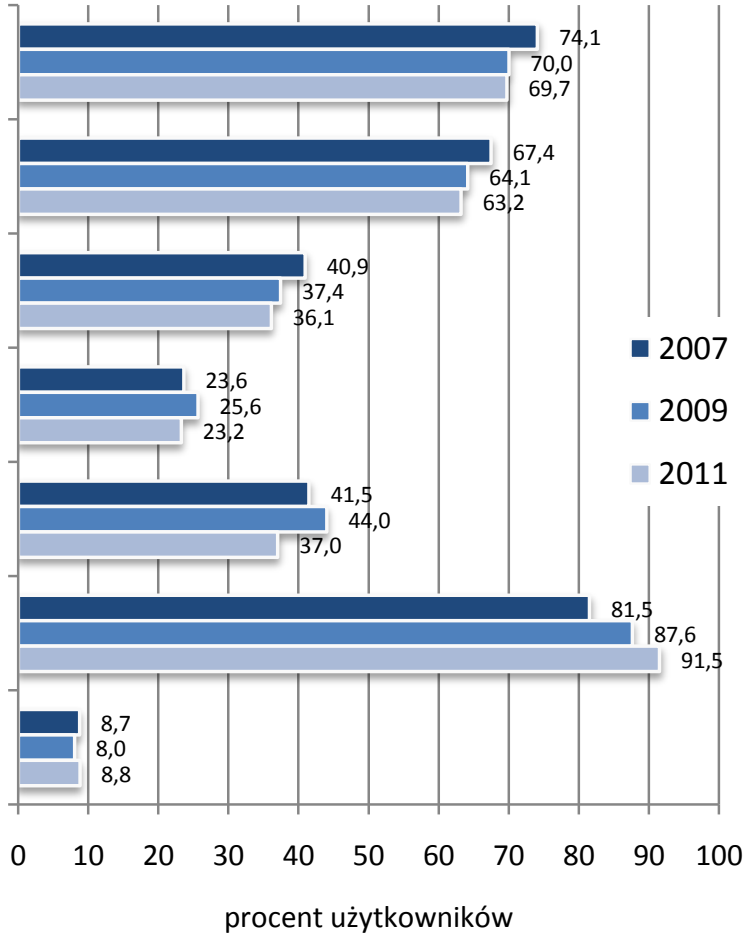

Wykres 7.3.1. Umiejętności korzystania z komputera w latach 2007-2011. 
Tabela 7.3.1. Umiejętności korzystania z komputerów oraz wszechstronność korzystania z internetu wśród użytkowników z różnych grup (w proc.).

\begin{tabular}{|c|c|c|c|c|}
\hline & \multirow{2}{*}{ Grupa } & \multirow{2}{*}{$\begin{array}{c}\text { Umiejętności obsługi } \\
\text { komputera }^{99}\end{array}$} & \multicolumn{2}{|c|}{ Wszechstronność korzystania $\mathrm{z}$ internetu } \\
\hline & & & 2009 & 2011 \\
\hline Ogółem & & 53 & 57,2 & 57,3 \\
\hline \multirow[t]{2}{*}{ Płeć } & Mężczyźni & 56 & 59,8 & 59,2 \\
\hline & Kobiety & 51 & 54,7 & 55,4 \\
\hline \multirow[t]{6}{*}{ Wiek } & 16-24 lat & 64 & 67,9 & 71,1 \\
\hline & 25-34 lat & 58 & 64,8 & 65,4 \\
\hline & $35-44$ lat & 49 & 52,2 & 53,2 \\
\hline & 45-59 lat & 43 & 42,0 & 41,6 \\
\hline & $60-64$ lat & 39 & 35,0 & 37,7 \\
\hline & 65 i więcej lat & 36 & 30,2 & 32,1 \\
\hline \multirow{9}{*}{$\begin{array}{l}\text { Status społeczno- } \\
\text { zawodowy }\end{array}$} & Prac. Sektora publicznego & 55 & 54,4 & 54,5 \\
\hline & Prac. Sektora prywatnego & 53 & 59,6 & 58,8 \\
\hline & Prywatni przedsiębiorcy & 55 & 58,1 & 54,9 \\
\hline & Rolnicy & 34 & 36,5 & 37,9 \\
\hline & Renciści & 38 & 50,0 & 42,1 \\
\hline & Emeryci & 36 & 32,5 & 33,6 \\
\hline & Uczniowie i studenci & 67 & 67,8 & 72,0 \\
\hline & Bezrobotni & 50 & 58,0 & 59,7 \\
\hline & Inni bierni zawodowo & 44 & 53,2 & 51,7 \\
\hline \multirow{5}{*}{$\begin{array}{l}\text { Wykształcenie z } \\
\text { wyodrębnieniem } \\
\text { osób uczących } \\
\text { się }\end{array}$} & Podstawowe i niższe & 35 & 44,5 & 45,5 \\
\hline & Zasadnicze/ gimnazjum & 38 & 45,3 & 45,6 \\
\hline & Średnie & 47 & 53,6 & 51,3 \\
\hline & Wyższe i policealne & 61 & 61,2 & 61,5 \\
\hline & Uczący się & 67 & 67,8 & 72,0 \\
\hline \multirow{6}{*}{$\begin{array}{l}\text { Wielkość } \\
\text { miejscowości } \\
\text { zamieszkania }\end{array}$} & Miasta powyżej 500 tys. & 59 & 64,7 & 61,1 \\
\hline & Miasta $200-500$ tys. & 57 & 64,3 & 61,1 \\
\hline & Miasta $100-200$ tys. & 54 & 58,7 & 57,6 \\
\hline & Miasta $20-100$ tys. & 52 & 56,0 & 55,9 \\
\hline & Miasta poniżej 20 tys. & 51 & 54,1 & 56,2 \\
\hline & Wieś & 50 & 51,4 & 55,0 \\
\hline \multirow{4}{*}{$\begin{array}{l}\text { Dochody na } \\
\text { osobę w } \\
\text { gospodarstwie } \\
\text { domowym }\end{array}$} & Pierwszy kwartyl & 52 & 53,4 & 54,3 \\
\hline & Drugi kwartyl & 54 & 56,2 & 57,0 \\
\hline & Trzeci kwartyl & 55 & 56,4 & 55,9 \\
\hline & Czwarty kwartyl & 61 & 60,3 & 60,8 \\
\hline
\end{tabular}

Umiejętności korzystania z komputera są wśród użytkowników silnie zróżnicowane i zależą od tych samych czynników, co fakt używania komputerów i internetu (tabela 7.3.1). Osoby z grup, w których użytkowników jest proporcjonalnie więcej, mają również wyższe umiejętności korzystania. Powyższa tabela pokazuje wyłącznie osoby korzystające $\mathrm{z}$ tych technologii, dzięki czemu możliwe jest porównanie kompetencji użytkowników z różnych grup. Większe umiejętności posiadają osoby młodsze, lepiej wykształcone, uczące się, bądź pracujące, a także więcej zarabiające i mieszkające w większych miejscowościach (choć w tym ostatnim przypadku różnice nie są duże). Największe różnice są związane z wykształceniem i wiekiem. Nieco większe umiejętności korzystania posiadają mężczyźni niż kobiety, ale te różnice nie są duże.

\subsubsection{Czas poświęcany na korzystanie z komputerów}

Średni czas spędzony przy komputerze w okresie jednego tygodnia to nieco ponad 15 godzin. Co ciekawe, obecnie wraz z przyrostem liczby osób korzystających z komputerów i internetu średnia ta jest coraz niższa. W 2009 roku użytkownicy korzystali średnio 16 godzin tygodniowo, a w 2007 roku jeszcze nieco więcej. Wynika to z mniej intensywnego wykorzystania komputerów przez osoby, które zaczęły z nich stosunkowo niedawno korzystać. Ci, którzy w poprzedniej edycji badania jeszcze nie używali komputerów, poświęcają na to teraz średnio 7 godzin i 15 minut. Natomiast ci, którzy korzystają dłużej aż 17 i pół godziny tygodniowo.

Przeciętny użytkownik spędza przy komputerze 10 godzin tygodniowo. Osoby korzystający niewiele - do dwóch godzin tygodniowo -- to 19 proc. użytkowników. Do 7 godzin tygodniowo korzysta 42 proc. Przynajmniej 21 godzin tygodniowo z komputera korzysta 22 proc. użytkowników (w 200925 proc.). Osoby spędzające przy komputerze 40 i więcej godzin stanowią około 12 proc. użytkowników (dwa lata temu 14 proc.). Odsetki te są prawie takie same jak w 2007 roku,

Ilość czasu spędzanego z komputerem zmieniała się w ostatnich latach w ciekawy sposób. Mniej więcej do 2007 roku obserwowaliśmy zwiększanie się liczby godzin używania komputerów. Po części mogło to wynikać z upowszechnienia się w tym okresie stałych łączy internetowych, pozwalających w mniej ograniczony sposób korzystać z sieci. W kolejnych latach i w okresie 2007-2009 zmiany były minimalne. Natomiast obecnie średni czas

\footnotetext{
${ }^{99}$ Średni procent umiejętności spośród 9 czynności.
} 
spędzany przed monitorem jest nieco krótszy, choć jest to efekt mało intensywnego korzystania przez nowych użytkowników, bo osoby z większym stażem robią to coraz intensywniej.

W pierwszej dekadzie XXI wieku rósł czas poświęcany na korzystanie z internetu. Samo korzystanie z internetu stawało się również coraz istotniejszym sposobem zastosowania komputerów. Obserwowaliśmy wzrost udziału czasu spędzanego w sieci w ogóle czasu spędzanego z komputerem. Wynikał on między innymi z tego, że więcej osób korzystało z sieci w domu i znacznie więcej miało stałe łącze. Większa dostępności internetu sprzyjała też intensywniejszemu korzystaniu nowych użytkowników, a dodatkowo wraz ze stażem korzystania z internetu, rosła wszechstronność używania sieci i w konsekwencji również czas na to poświęcany. Obecnie, kiedy prawie każdy komputer ma stały dostęp do internetu, trudno już oddzielić czas poświęcany na korzystanie z internetu od czasu spędzanego z komputerem. Dlatego też w obecnej edycji zrezygnowaliśmy jz pytania respondentów o czas korzystania $\mathrm{z}$ internetu.

\subsubsection{Wszechstronność korzystania z internetu}

Korzystanie z komputerów i internetu obejmuje bardzo wiele różnych możliwych czynności i dla różnych użytkowników może oznaczać zupełnie co innego. Analiza czynności, jakie Polacy wykonują w sieci, pokazuje przede wszystkim wzrost wszechstronności wykorzystania internetu. Przeciętny użytkownik korzysta na coraz więcej różnych sposobów, choć zmiany te nie wydają się już tak szybkie jak w ubiegłych latach. Po części może to wynikać z mało intensywnego korzystania przez osoby, które internautami zostały niedawno, to jest w okresie ostatnich dwóch lat. Nowi użytkownicy wykonywali w sieci średnio 8,6 spośród 24 badanych zastosowań (36 proc.), natomiast ci z większym stażem średnio 14,2. Różnica jest więc znaczna.

Podobnie jak umiejętności korzystania z komputerów, również wszechstronność korzystania z internetu jest bardzo zróżnicowana. Procent zastosowań internetu (spośród 24 badanych czynności) w różnych grupach użytkowników przedstawia tabela 7.3.1. Intensywniej $\mathrm{i}$ w sposób bardziej zróżnicowany korzystają przede wszystkim osoby młodsze, uczniowie i studenci. Nieco więcej czynności w sieci wykonują też osoby lepiej wykształcone. Najmniej wszechstronnie korzystają natomiast internauci będący emerytami lub rolnikami. Bardzo nieduże różnice związane są z płcią, wielkością miejscowości zamieszkania i dochodami. 


\subsection{Społeczne wymiary korzystania $z$ internetu}

Jak zostało pokazane we wcześniejszych częściach, w ostatnich latach nastąpił nie tylko znaczący wzrost liczby użytkowników internetu, ale również bardzo mocno zmieniła się struktura korzystających z sieci. Podwyższa się przeciętny wiek, coraz większa część użytkowników ma słabsze wykształcenie, proporcjonalnie więcej jest też osób z mniejszych miejscowości. Jednocześnie rozwijają się i zmieniają usługi dostępne w internecie i poszerza się spektrum jego zastosowań. To wszystko przekłada się także na zmiany sposobów korzystania z internetu, choć jak pokażemy, zmiany te są mniejsze niż mogłoby się wydawać.

W tej części zbadamy różne sposoby korzystania z internetu oraz związek korzystania z sytuacją życiową internautów i ich aktywnością poza siecią.

\subsubsection{Komunikacja przez internet i portale spolecznościowe}

Komunikacja jest jednym z podstawowych celów korzystania z internetu. Zdecydowana większość komunikacji w sieci to kontakty z osobami znanymi z codziennego życia. Narzędzia komunikacji elektronicznej wykorzystywane są obecnie bardzo podobnie jak w ostatnich kilku latach. Najistotniejsze zmiany związane są z mniejszą regularnością korzystania z komunikatorów internetowych, bo choć od czasu do czasu używa ich prawie 80 proc. internautów, to jednak tylko połowa robi to regularnie. Nieco mniej regularne jest wykorzystanie poczty elektronicznej. Podobnie jak w przypadku komunikatorów może to być związane z upowszechnieniem się serwisów społecznościowych i z tym, że część komunikacji odbywa się właśnie w tych serwisach.

Niewiele zmienia się korzystanie $\mathrm{z}$ innych form komunikacji internetowej. Upowszechnia się telefonia internetowa, której używa już ponad dwie trzecie internautów (w 2009 roku 63 proc. a w 200532 proc.). Jednak cały czas stosunkowo niewiele osób korzysta z niej regularnie. Podobnie jak w ubiegłych latach, również teraz tylko 24 proc. deklaruje dzwonienie przez sieć w okresie tygodnia.

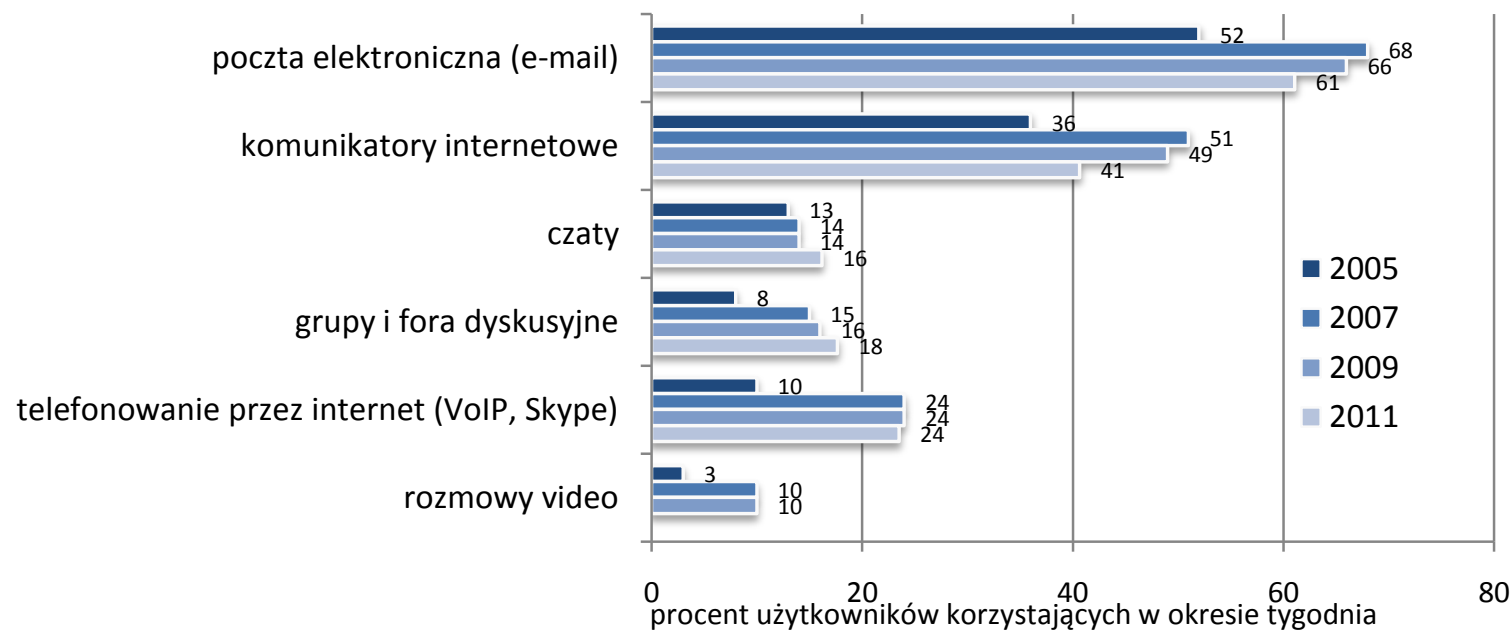

Wykres 7.4.1. Narzędzia komunikacji internetowej wykorzystywane przez użytkowników w okresie jednego tygodnia w latach 2005-2011

Już dwa lata temu ponad połowa użytkowników deklarowała regularne korzystanie z serwisów społecznościowych, a kontakt z nimi miało ponad 80 proc. internautów. Obecnie do posiadania konta w którymś z portali i korzystania z niego od czasu do czasu przyznaje się już 68 proc. internautów, a więc ponad 40 proc. Polaków. Prawie 35 proc. Polaków ma konto w serwisie NK.pl (dawniej nasza-klasa.pl), 20 proc. na Facebooku, a 13 proc. w innym serwisie. Warto też podkreślić, że użytkownicy różnych serwisów to najczęściej te same osoby. W tej chwili aż 80 proc. polskich użytkowników Facebooka ma też konto i korzysta z NK.pl.

Mimo znacznie większego nagłośnienia Facebooka i znacznie większej jego widoczności poza internetem i w innych mediach, cały czas znacznie więcej Polaków korzysta z rodzimego serwisu. W kwietniu 2011 konto na NK.pl miało i korzystało z tego serwisu 57,5 proc. internautów, na Facebooku tylko 34 proc. internautów; 22 proc. użytkowników ma konto w innym serwisie społecznościowym. Przekłada się to na nieco ponad $11 \mathrm{mln}$ osób na NK.pl i 6,5mln na Facebooku. Wyniki te są dokładnie zbieżne z liczbą użytkowników z Polski podawaną przez Facebook, a i dane dla NK.pl nie odbiegają od tego, co wiadomo z innych statystyk. Jednak, jak pokazują dane z badania Megapanel PBI/Gemius z Facebooka bardzo często korzystają również osoby, które nie mają założonego tam konta. W rezultacie, mimo dużej różnicy w liczbie zarejestrowanych użytkowników na oba serwisy zagląa już podobna liczba osób. To po części efekt większej obecności Facebooka w różnych miejscach sieci, a także w innych mediach, przez co znacznie więcej osób ma szansę na nawet przypadkowe wejście lub zainteresowanie się chociażby promowanym gdzie indziej fanpage'm. 
Z serwisów społecznościowych korzystają przede wszystkim młodsi internauci. Inne czynniki społecznodemograficzne mają stosunkowo mniejsze znaczenie; różnicują natomiast to, z których serwisów użytkownicy korzystają. Szerzej ten problem został omówiony w części 7.4.3.

\subsubsection{Korzystanie $\mathrm{z}$ internetu a relacje spoleczne}

Począwszy od połowy lat 90-tych XX wieku trwa debata o wpływie korzystania $\mathrm{z}$ internetu na relacje międzyludzkie, izolację społeczną i kapitał społeczny. Warto w tym miejscu prześledzić to zagadnienie w wynikach Diagnozy Społecznej.

W pierwszej kolejności należy zaznaczyć, że użytkownicy internetu to generalnie osoby posiadające znacznie więcej relacji społecznych niż osoby niekorzystające. W sporej mierze wynika to $\mathrm{z}$ innych różnic pomiędzy tymi grupami, przede wszystkim wieku, ale też aktywności zawodowej. Osoby młodsze częściej mają więcej znajomych, a jednocześnie częściej korzystają z sieci. Dlatego obserwując związek liczby relacji i korzystania z internetu czy serwisów społecznościowych, widzimy przede wszystkim efekt współwystępowania niż zależności o bardziej przyczynowo-skutkowym charakterze (wykres 7.4.2). Nad faktycznymi efektami korzystania będziemy mogli się zastanowić dalej, analizując zmiany zachodzące w czasie, na co pozwala panelowy charakter badania.

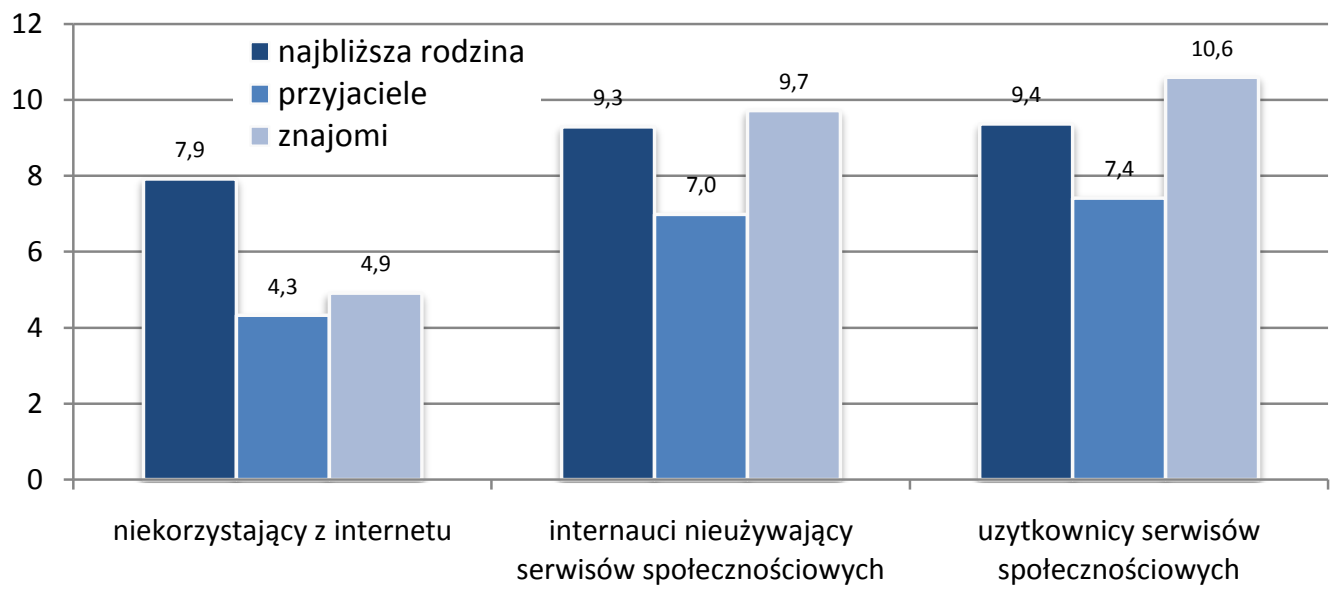

Wykres 7.4.2. Liczba osób, z różnych kręgów z którymi utrzymywany jest regularny kontakt, w zależności od korzystania z internetu i serwisów społecznościowych.

Dokładniejsze analizy statystyczne pokazują, że nawet jeśli wykluczymy różnice związane z wiekiem, to i tak użytkownicy internetu utrzymują znacznie więcej relacji. Mają więcej przeciętnie o jedną osobę z kręgu rodziny. Również deklarują regularne kontakty z większą liczbą przyjaciół, dodatkowo więcej przyjaciół mają korzystający z serwisów społecznościowych, szczególnie z Facebooka. Największe różnice są związane z liczbą znajomych. Użytkownicy Facebooka kontaktują się regularnie $\mathrm{z}$ najszerszym gronem osób - różnica w stosunku do niekorzystających z internetu osób tej samej płci i będących w tym samym wieku, wynosi czterech znajomych (dla korzystających z innych serwisów społecznościowych różnica wynosi dwie osoby).

Nieco inny obraz wyłania się z danych, gdy przeanalizujemy zmiany jakie zachodzą w czasie. W latach 20052011 korzystanie z internetu nie miało żadnego wpływu na zmianę liczby przyjaciól, z którymi badani utrzymują regularny kontakt. Miało natomiast znaczenie dla kontaktów z innymi osobami. Internautom wzrosła liczba relacji z osobami z rodziny, a także ze znajomymi, jednak oba te efekty dotyczą wyłącznie tych, którzy nie korzystają z serwisów społecznościowych (w większym stopniu tych, którzy rozpoczęli korzystanie z sieci w ostatnich latach).

Podsumowując przedstawione tu wyniki należy stwierdzić, że choć internauci, szczególnie ci korzystający z serwisów społecznościowych, mają wyraźnie więcej relacji społecznych i z większą liczbą osób utrzymują regularne kontakty poza internetem, to jednak liczba tych relacji znacząco się nie zwiększa. Jeśli już widoczne są jakieś zmiany, to mają one dość nieoczekiwany charakter. Korzystanie z internetu, ale nie z serwisów społecznościowych, sprzyja regularnym kontaktom $\mathrm{z}$ większą liczbą osób $\mathrm{z}$ rodziny i znajomych niż sześć lat temu. Natomiast korzystanie z Facebooka i/lub NK.pl jest związane z brakiem takich pozytywnych efektów i nie ma żadnego wpływu na zmianę liczby kontaktów.

\subsubsection{Podziały klasowe w internecie}

W analizie korzystania z serwisów społecznościowych bardzo ciekawa wydaje się kwestia migracji użytkowników pomiędzy różnymi serwisami. O zagadnieniu tym bardzo ciekawie pisała badaczka młodzieży i serwisów społecznościowych, danah boyd. Analizując zmiany popularności serwisów MySpace i Facebooka, pokazała ona 
pojawienie się różnic społecznych i klasowych w korzystaniu z tych dwóch serwisów ${ }^{100}$. Biali, wykształceni, mieszkający w większych miejscowościach oraz znajdujący się w lepszej sytuacji materialnej szybciej porzucali MySpace na rzecz Facebooka. Natomiast latynosi, osoby słabiej wykształcone, z mniejszych miejscowości i o niższym statusie materialnym, a także młodzież z domów o niższym wykształceniu rodziców, znacznie częściej korzystała z MySpace. Warto przeanalizować, od czego zależy korzystanie z dwóch najpopularniejszych serwisów, NK.pl i Facebooka w Polsce.

Już pierwsza analiza korzystania z serwisów społecznościowych w zależności od wykształcenia (wykres 7.4.3) pokazuje, że również w Polsce czynniki związane z pozycją społeczną mają znaczenie. Nie zaskakuje, że z portali społecznościowych korzystają przede wszystkim osoby uczące się lub studiujące. Co ciekawe, wśród pozostałych osób wykształcenie nie ma znaczenia, czy internauci korzystają z Facebooka lub z NK.pl, mają natomiast znaczenie, jeśli chodzi o to, z którego serwisu korzystają. W każdej z grup wykształcenia z NK.pl korzysta ponad połowa internautów, natomiast z Facebooka korzystają znacznie częściej użytkownicy lepiej wykształceni. Wśród tych z wyższym wykształceniem większa jest także grupa użytkowników serwisów społecznościowych, którzy nie mają konta na NK.pl.

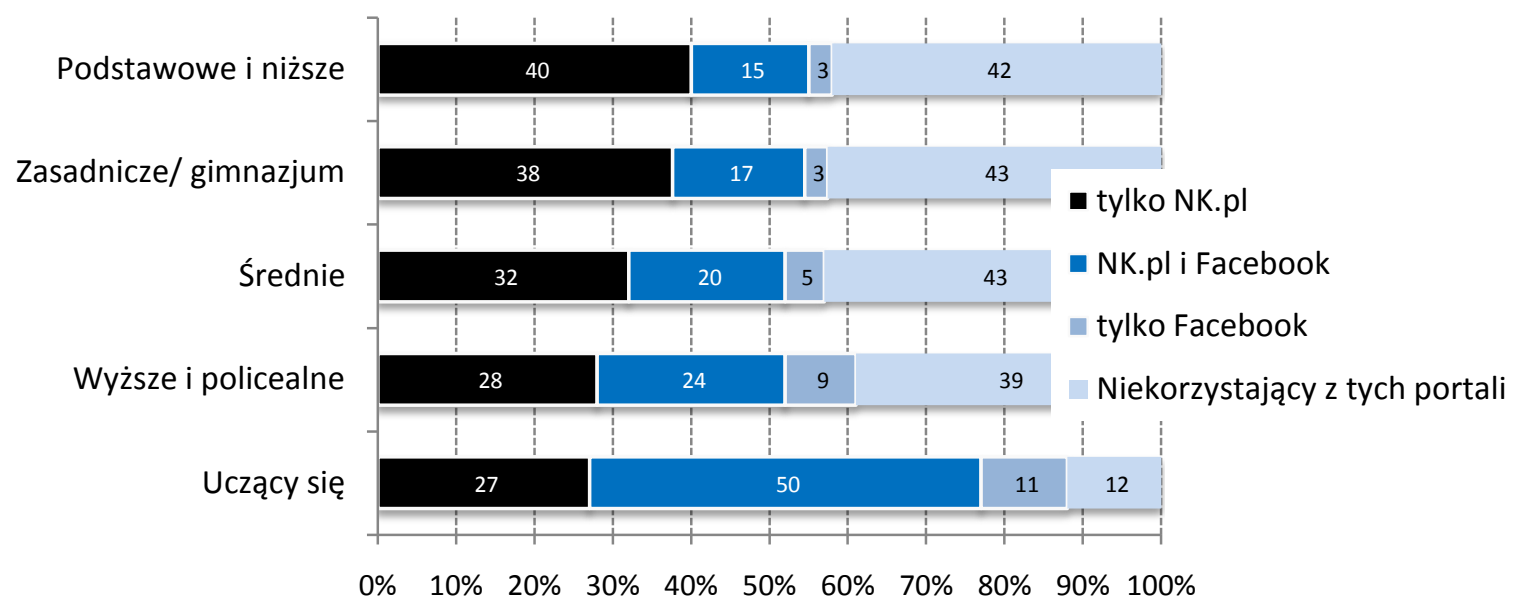

Wykres 7.4.3. Korzystanie z NK.pl i Facebooka wśród internautów w grupach ze względu na wykształcenie.

Wśród internautów z największych miast 16 proc. korzysta z Facebooka i jednocześnie nie posiada konta $\mathrm{W}$ NK.pl, wśród użytkowników mieszkających na wsi takich osób jest tylko 3 proc. Z drugiej strony, z NK.pl a nie z Facebooka korzysta 20 proc. internautów z największych miast i aż 38 proc. ze wsi. Warto też zwrócić uwagę, że to internauci mieszkający na wsi i w mniejszych miastach częściej korzystają z serwisów społecznościowych. Może to być efekt tego, że w tych miejscowościach stosunkowo rzadziej niż w dużych miastach, korzystają z internetu osoby starsze.

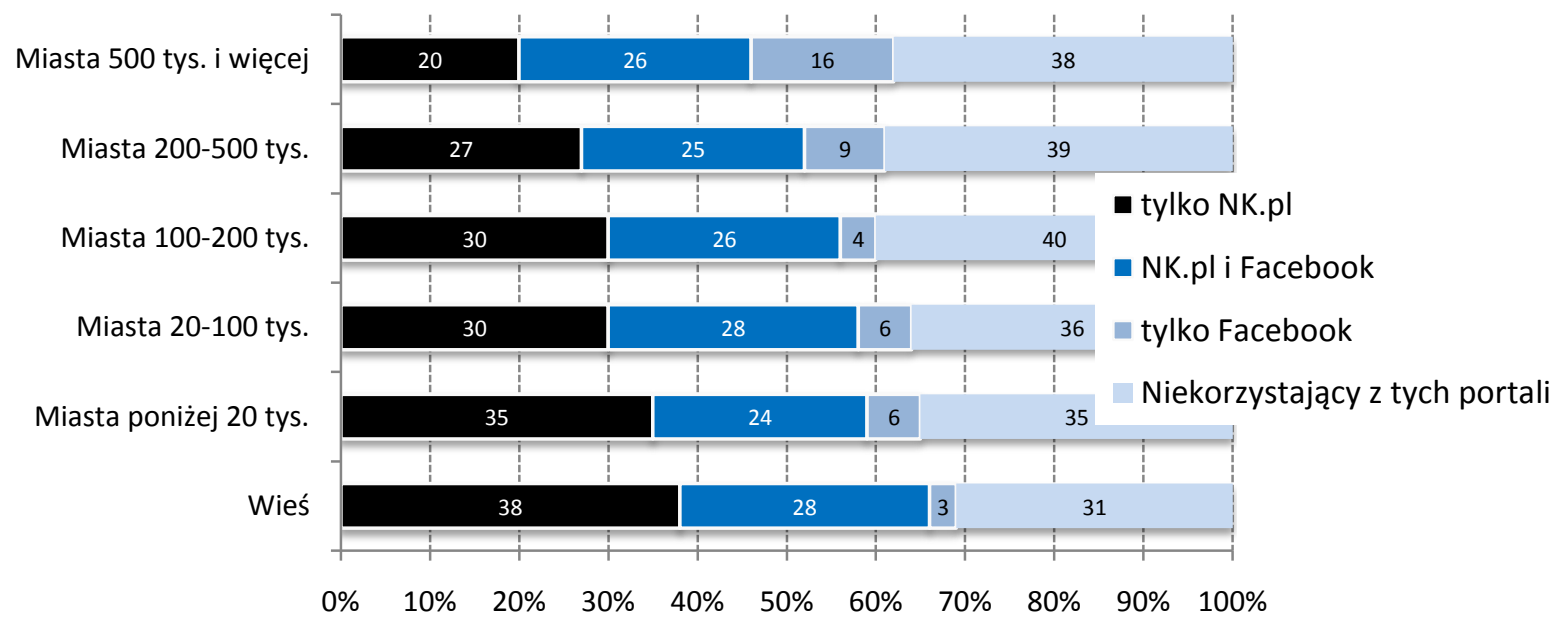

Wykres 7.4.4. Korzystanie z NK.pl i Facebooka wśród internautów w grupach ze względu na wielkość miejscowości zamieszkania.

\footnotetext{
100 boyd, danah. 2007. "Viewing American class divisions through Facebook and MySpace ." Apophenia Blog Essay. June 24 . http://www.danah.org/papers/essays/ClassDivisions.html
} 
Duże zróżnicowanie korzystania przez użytkowników internetu z serwisów społecznościowych w zależności od statusu społeczno-zawodowego przedstawia wykres 7.4.5. Co ciekawe, poza uczniami i studentami najczęściej serwisów tych używają osoby bezrobotne i bierne zawodowo. We wszystkich grupach dominuje korzystanie z NK.pl. Facebook ma najwięcej użytkowników, wśród osób uczących się, a także pracowników sektora prywatnego i przedsiębiorców. Korzysta $\mathrm{z}$ niego również wielu bezrobotnych, oni jednak w większości mają również konta na NK.pl.

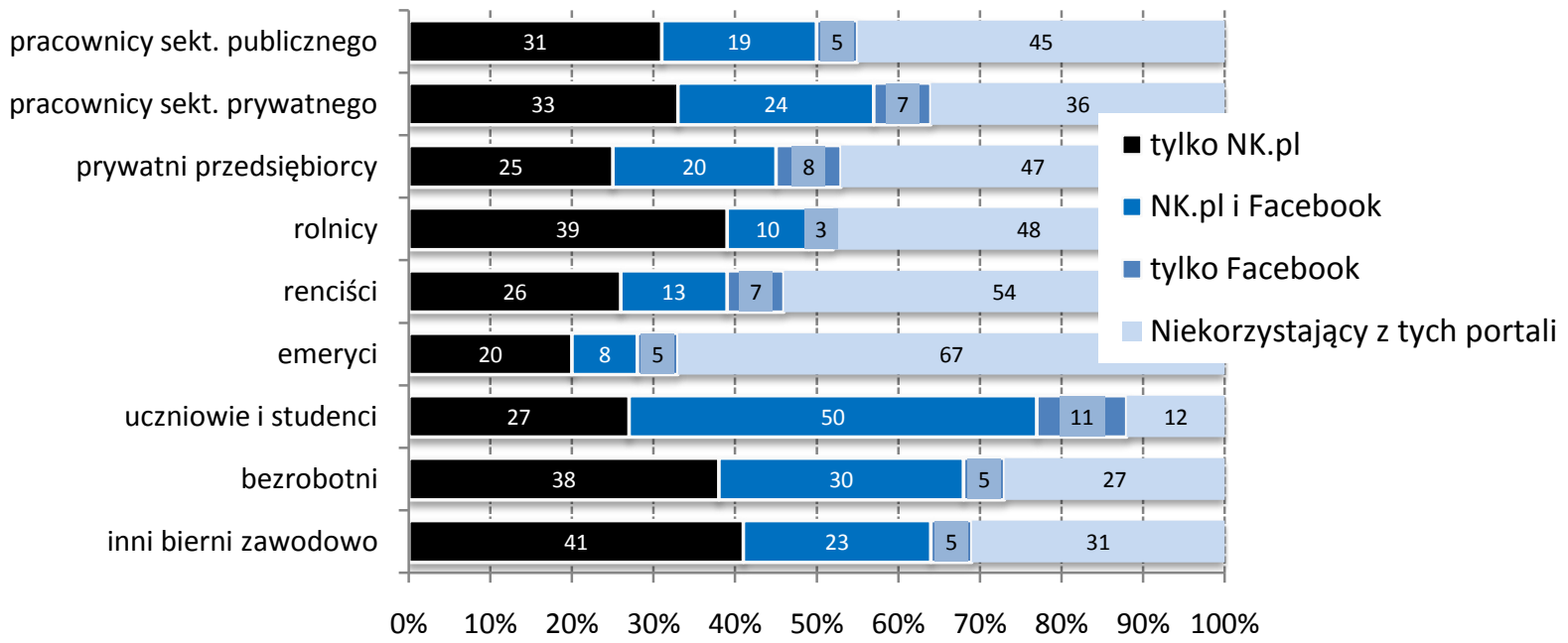

Wykres 7.4.5. Korzystanie z NK.pl i Facebooka wśród internautów w grupach ze względu na status społecznozawodowy.

Ciekawie prezentuje się również zależność związana z dochodami. Częściej z serwisów społecznościowych korzystają internauci z gospodarstw domowych o niższych dochodach. W tych ostatnich największa jest także przewaga NK.pl nad Facebookiem. Z kolei korzystających z Facebooka i niemających konta na NK.pl można najczęściej znaleźć wśród osób z wyższymi dochodami.

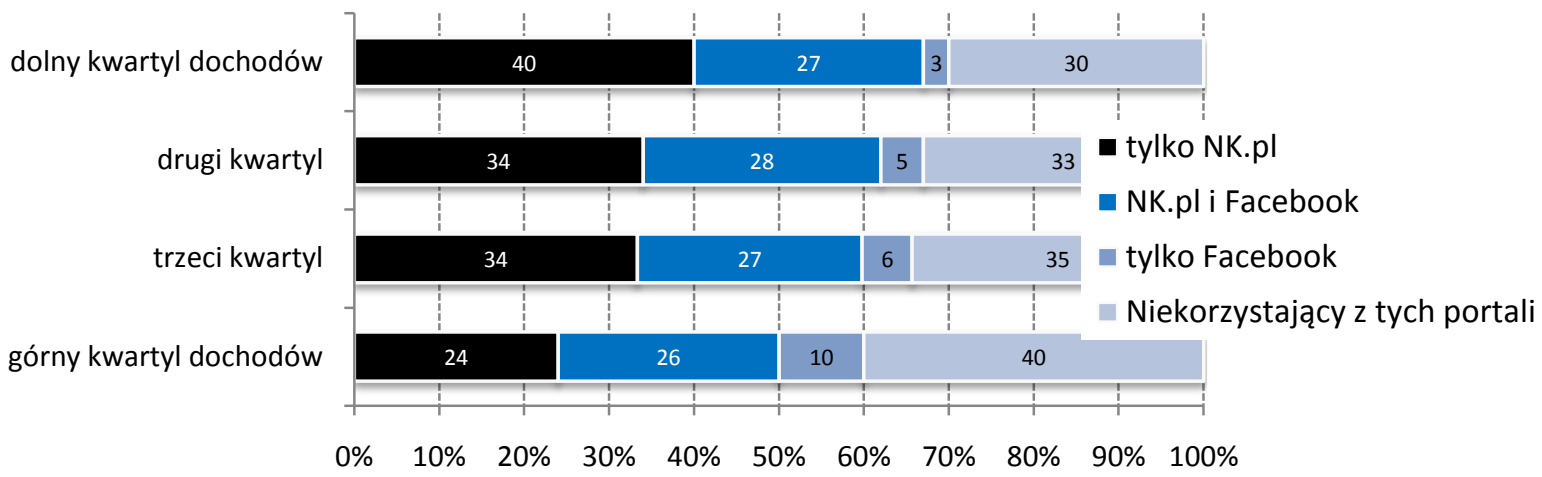

Wykres 7.4.6. Korzystanie z NK.pl i Facebooka wśród internautów w grupach ze względu na dochody na osobę w gospodarstwie domowym.

W Polsce, podobnie jak w USA, widać wyraźne różnice klasowe w korzystaniu z serwisów społecznościowych. Do pewnego stopnia jest to jednak efekt samej natury procesu upowszechniania się poszczególnych serwisów. Na początku zaczynają korzystać raczej osoby młodsze, lepiej wykształcone i z większych miejscowości. W przypadku Facebooka w Polsce dodatkowe znaczenie ma to, że jest to serwis zagraniczny, który w początkowym okresie swojego funkcjonowania był znany raczej tylko osobom mającym kontakt z ludźmi z innych krajów, pracującym w branży internetowej, aktywniejszym użytkownikom. Dopiero stopniowo, wraz z upowszechnieniem korzystania z danego serwisu dołączają do niego osoby z innych grup społecznych. W dłuższej perspektywie taka dynamika i swego rodzaju moda na Facebooka, źle wróży serwisowi NK.pl.

\subsubsection{Spędzanie czasu wolnego i uczestnictwo w kulturze}

Osoby korzystające z internetu prowadzą aktywniejsze życie społeczne i kulturalne niż osoby niekorzystające (wykres 7.4.7). W okresie miesiąca 37 proc. użytkowników było w kinie, teatrze lub na koncercie, wśród pozostałych osób ledwie 6 proc. W restauracji kawiarni lub pubie było w okresie miesiąca 53 proc. internautów i 
tylko 11 proc. pozostałych osób. Na spotkaniu towarzyskim było odpowiednio 72 proc. użytkowników i 36 proc. innych osób.

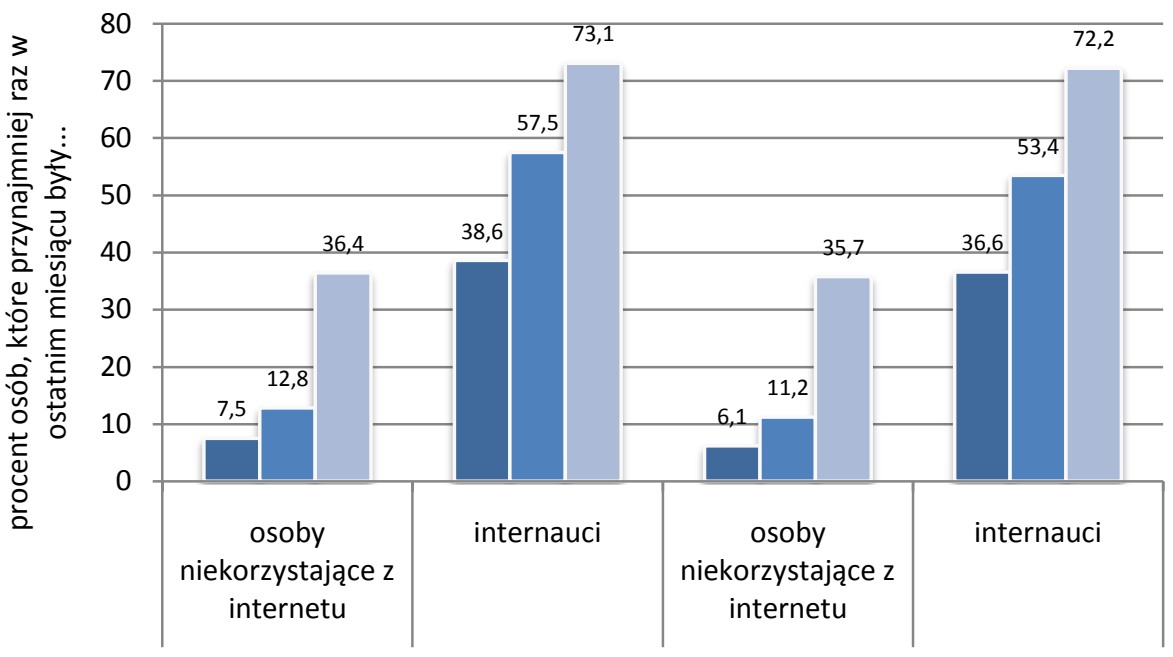

w kinie, teatrze lub na koncercie

w restauracji, kawiarni, pubie

na spotkaniu towarzyskim

Wykres 7.4.7. Różnice między internautami a osobami niekorzystajacymi pod względem aktywności kulturalnej $i$ towarzyskiej w okresie jednego miesiqca.

Oczywiście przedstawione tu różnice wynikają przede wszystkim z innych czynników niż samo korzystanie z internetu. Znaczenie ma z pewnością wiek, wykształcenie, zamożność, czy wielkość miejscowości zamieszkania. Wszystkie te czynniki są też związane z korzystaniem z internetu i stąd obserwowane zależności. Jednak samo korzystanie z internetu też może mieć znaczenie. Chociażby dlatego, że wpływa na sposób spędzania czasu wolnego. Ponadto w coraz większym stopniu to w internecie można znaleźć informacje o wydarzeniach kulturalnych, a także ich recenzje. Aby prześledzić znaczenie używania sieci, przyjrzyjmy się, jak w latach 20092011 zmieniał się procent osób uczestniczących w różnych wydarzeniach w czterech grupach wyodrębnianych według korzystania $\mathrm{z}$ internetu.

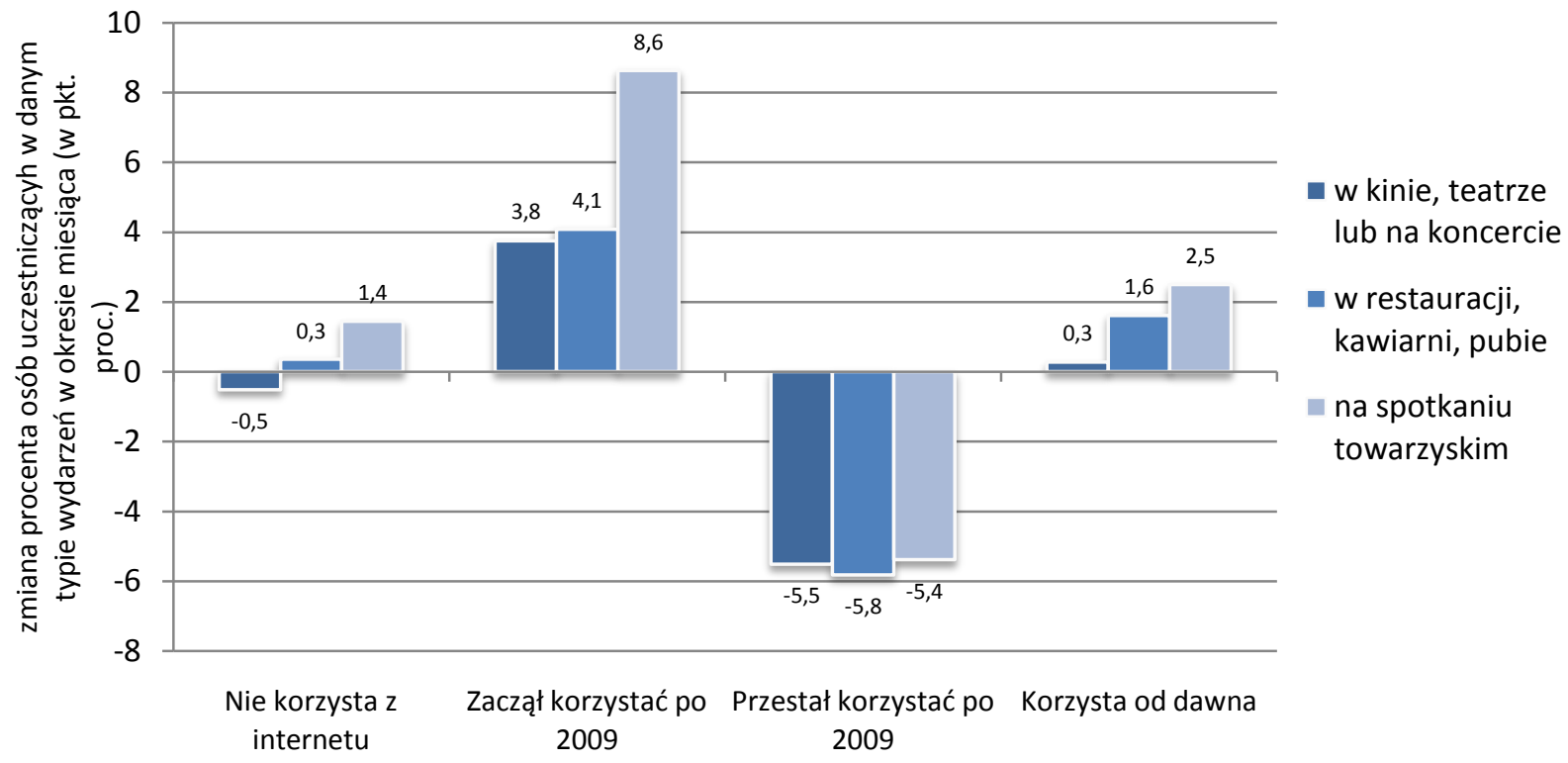

Wykres 7.4.8. Zmiana uczestniczenia w różnych typach wydarzeń w latach 2009-2011 w zależności od korzystania z internetu.

Jak możemy zaobserwować na wykresie 7.4.8, wśród osób, które nie korzystały z internetu ani w 2009 ani w 2011 roku, odsetek chodzących do kina, teatru lub na koncerty praktycznie się nie zmienił. Podobnie z chodzeniem do restauracji, kawiarni czy pubów. Nieznacznie zwiększyła się grupa uczestniczących w spotkaniach towarzyskich. Duży przyrost wszystkich tych aktywności jest za to widoczny wśród osób, które od 2009 roku zaczęły korzystać z internetu. Co ciekawe, wśród tych, którzy korzystali z sieci w 2009 roku, a obecnie tego nie robią, spadła również liczba uczestniczących $\mathrm{w}$ wydarzeniach. Wśród osób, które $\mathrm{z}$ internetu korzystają ponad dwa lata, zmiany są 
nieduże, o 2,5 p.p. więcej osób uczestniczy w spotkaniach towarzyskich. Jednak tak, jak pokazywał wykres 7.4.7, internauci i tak już wcześniej wykazywali się znacznie większą aktywnością.

Użytkownicy internetu poświęcają na oglądanie telewizji wyraźnie mniej czasu niż osoby niekorzystające. Prawie dwa razy częściej są wśród nich osoby, które w ogóle telewizji nie oglądają. Znacznie mniej z nich poświęca na oglądanie TV powyżej trzech godzin dziennie.

Warto zauważyć, że czas poświęcany przez Polaków na oglądanie TV niewiele się w ostatnich latach zmieniał. Zarówno wśród osób korzystających z internetu, jak i tych, którzy tego nie robią czas spędzany przed telewizorem jest niemal identyczny jak w 2009 roku. Również analiza zmian czasu poświęcanego na oglądanie telewizji w latach 2009-2011 pokazuje brak znaczenia korzystania z internetu. Także osoby, które w tym okresie zaczęły korzystać z sieci nie zmieniły swoich nawyków telewizyjnych.

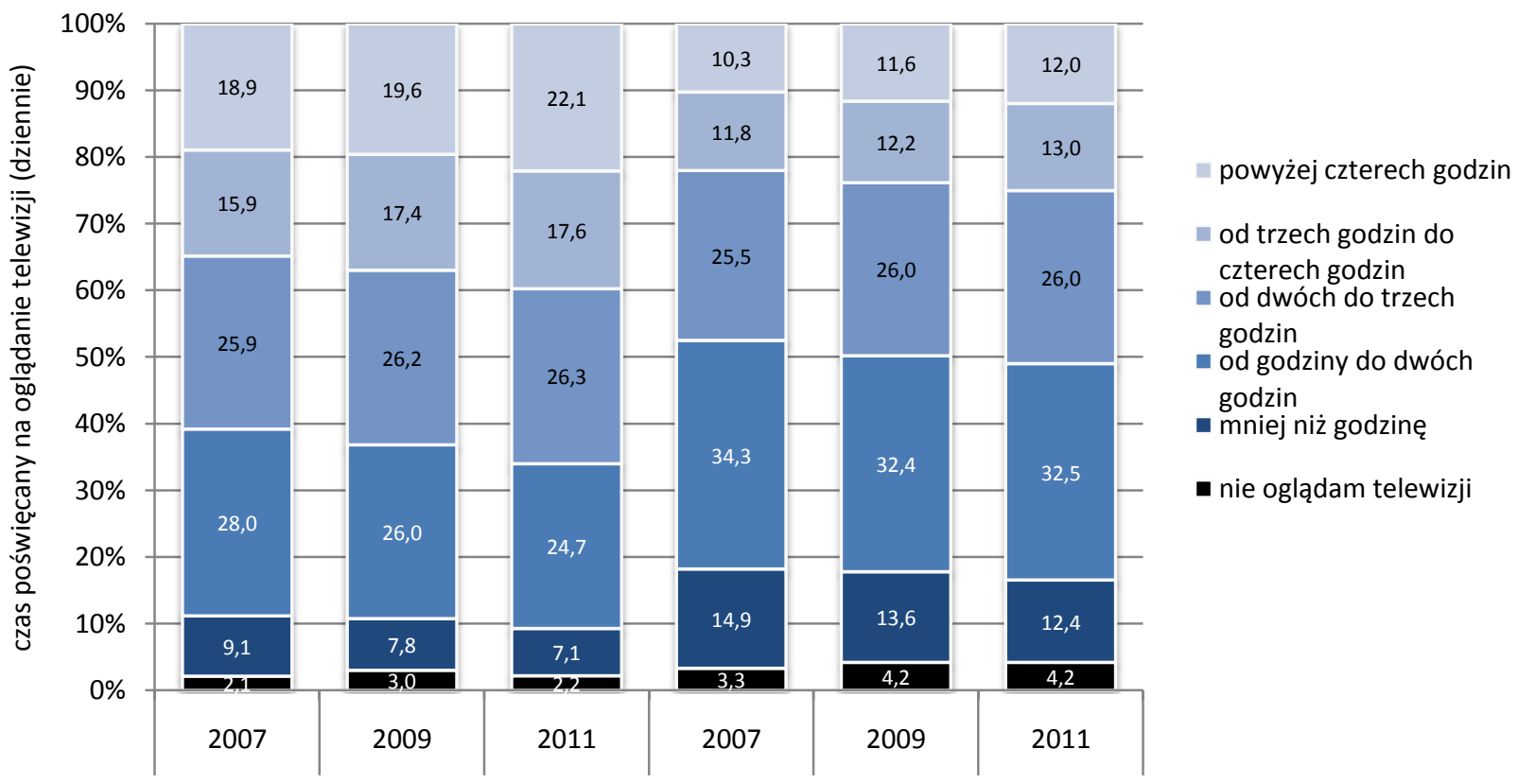

Wykres 7.4.9. Czas poświęcany na ogladanie telewizji w latach 2007-2011 wśród internautów i osób niekorzystajacych z sieci.

\subsubsection{Relacje i zaangażowanie społeczne a internet}

Osoby korzystające z internetu wykazują znacznie większą aktywność społeczną (wykres 7.4.10). Prawie dwa razy częściej angażują się na rzecz społeczności lokalnej. Częściej też biorą udział w różnego rodzaju zebraniach publicznych. Wśród internautów więcej jest osób będących członkami organizacji i stowarzyszeń, należy do nich 17,5 proc. $z$ nich i niecałe 11 proc. niekorzystających. Dodatkowo użytkownicy sieci dwukrotnie częściej należą do większej liczby tych organizacji.

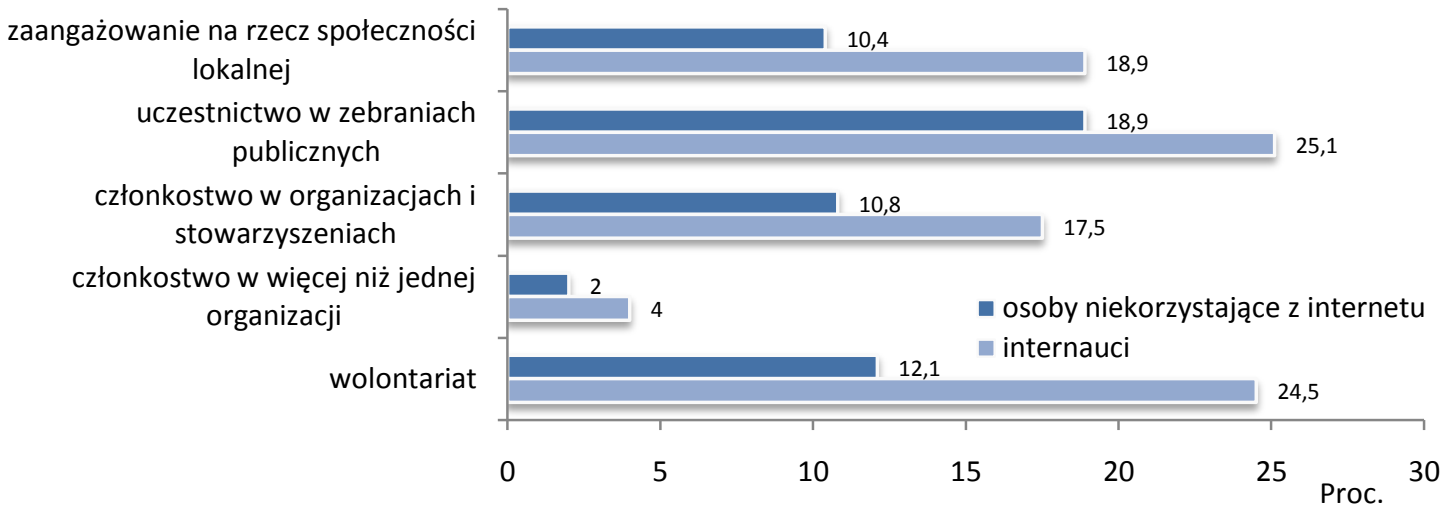

Wykres 7.4.10. Różnice między internautami a osobami niekorzystajacymi z internetu pod względem aktywności spolecznej.

Jakie znaczenie dla aktywności społecznej ma korzystanie z internetu? Aby odpowiedzieć na to pytanie, warto przeanalizować, jak zmienia się aktywność społeczna Polaków w zależności od tego, czy korzystają z komputerów i 
internetu, czy nie. Zaangażowanie na rzecz społeczności lokalnej zmieniało się w niewielkim stopniu, a wśród osób, które nie korzystały z internetu w latach 2009-2011, nie zmieniało się wcale. Wśród korzystających obecnie z internetu angażuje się nieco mniej osób niż jeszcze dwa lata temu. Jednak największy spadek nastąpił wśród osób, które przestały korzystać z internetu po 2009 roku. Inaczej zmienia się udział w zebraniach publicznych. Wśród użytkowników internetu przybyło uczestniczących w takich zebraniach o prawie 4 p.p., a wśród tych, co zaczęli korzystać w ostatnich dwóch latach, o ponad 6 p.p. Znacznie mniej wzrosła aktywność wśród osób niekorzystających z internetu, a wśród tych, którzy przestali korzystać z sieci, wręcz się obniżyła o 4 p.p. Zmienia się także członkostwo w organizacjach i stowarzyszeniach. Liczba osób, które zaczynają należeć do organizacji, jest zbliżona do liczby tych, którzy jeszcze w 2009 byli członkami przynajmniej jednej, a obecnie już nie są. Niewielkie przyrosty członkostwa w organizacjach widoczne są wśród tych osób, które korzystają z sieci. Szczególnie wzrosła aktywność nowych internautów, wśród których liczba osób należących do jakiejś działalności zwiększyła się o $2 \mathrm{p} \mathrm{p}$.

\subsubsection{Internet a wybory}

Zarówno wyniki obecnej edycji Diagnozy Społecznej, jak również poprzednich rund badania, pokazują, że przynajmniej od kilku lat osoby korzystające z internetu częściej biorą udział w wyborach. W ostatnich wyborach samorządowych w 2010 r., różnica była stosunkowo niewielka i wynosiła 2 p.p. W wyborach parlamentarnych różnica jest większa - w przeciwieństwie do wyborów samorządowych częściej głosują w nich osoby mieszkające w większych miastach, podczas gdy w wyborach lokalnych frekwencja jest wyższa w mniejszych miejscowościach. Według danych Diagnozy Społecznej 2009 w 2007 roku deklarowana frekwencja wyborcza wśród internautów była o 8,5 p.p. wyższa niż wśród osób niekorzystających. Bez wątpienia, również w obecnych wyborach częściej będą głosowali użytkownicy.

Co ciekawe, w pierwszej połowie 2011 roku to wśród internautów było mniej osób zdecydowanych na kogo głosować. Różnica wynosiła aż 5 p.p. Partiom politycznym opłaca się więc wykorzystywać internet do docierania do osób, które jeszcze są niezdecydowane, ale ostatecznie wezmą udział w wyborach.

Niniejszy rozdział pisany był w pierwszych dniach kampanii wyborczej 2011 roku. Na podstawie przywołanych tu wyników należy spodziewać się, że kampania ta będzie rozgrywać się w sieci w znacznie większym stopniu niż to miało miejsce dotychczas. $Z$ drugiej strony, można mieć jednak wątpliwości, czy partie będą umiały dobrze wykorzystać internet. Ostatnie wybory samorządowe pokazały, że politycy na ogół nie rozumieją sieci, a partie nie potrafiły skutecznie wykorzystać internetu (Zając, Batorski, 2011).

\subsubsection{Aktywność zawodowa internautów i osób niekorzystających}

Osoby korzystające z internetu znacznie częściej pracują w porównaniu do tych, którzy z internetu nie korzystają. Jak można zaobserwować na wykresie 7.4.11, wśród osób mających 25-40 lat odsetek pracujących jest wśród internautów o około 20 p.p. wyższy niż wśród osób niekorzystających. Wśród tych ostatnich znacznie więcej jest za to osób bezrobotnych i biernych zawodowo. Różnice są nieco mniejsze dla grupy wieku 40-50 lat a większe dla osób w wieku przedemerytalnym.

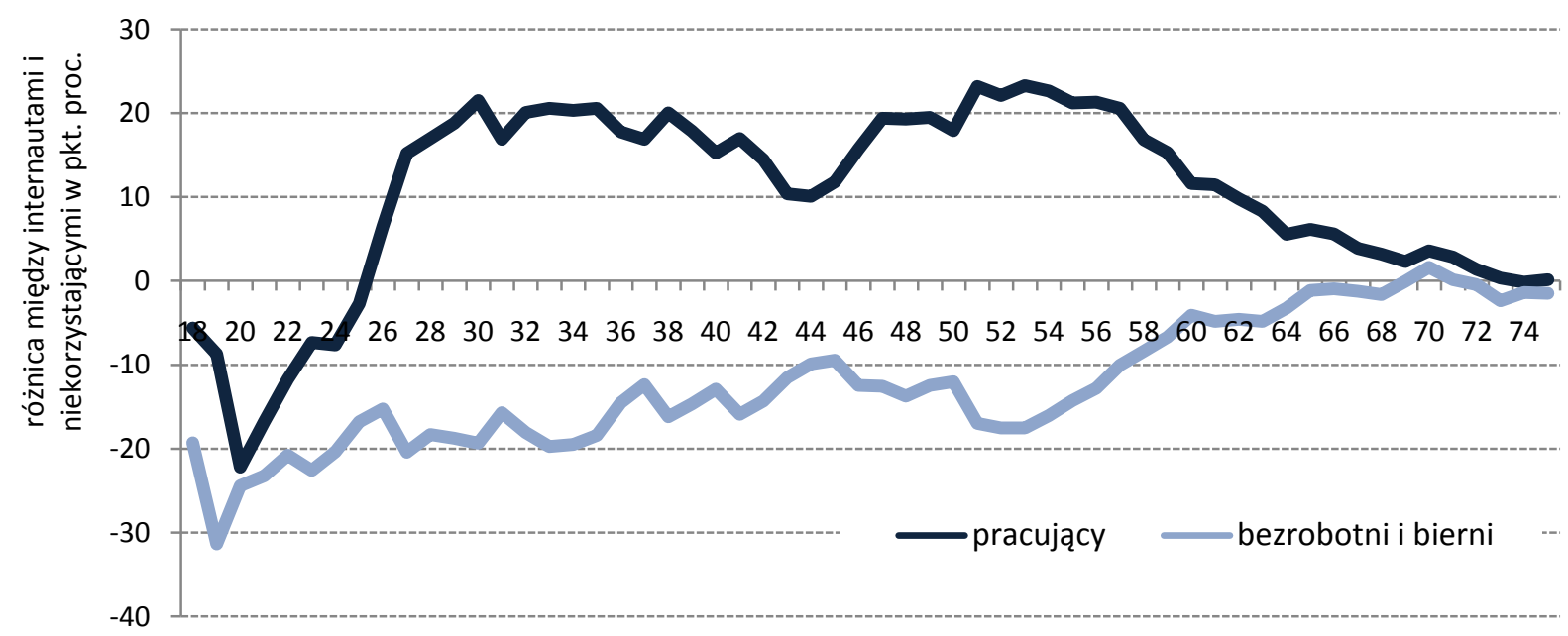

Wykres 7.4.11. Różnice $w$ częstości bycia zatrudnionym oraz bezrobotnym lub biernym między internautami a osobami niekorzystajacymi z internetu w zależności od wieku (w pkt. proc).

Korzystanie z internetu wiąże się z mniejszym zagrożeniem bezrobociem i większymi szansami na znalezienie pracy w przypadku jej braku. Spośród osób, które w 2009 roku były bezrobotne lub bierne zawodowo, obecnie 
pracę posiada 35 proc. korzystających z internetu i 27 proc. tych, którzy go nie używają. W okresie tych dwóch lat pracę straciło 7 proc. internautów i 11 proc. pozostałych osób.

Jeżeli przyjrzymy się wyłącznie osobom pracującym, dostrzeżemy dalsze różnice pomiędzy użytkownikami i osobami niekorzystającymi z internetu. Ci pierwsi wyraźnie częściej zmieniają pracę na lepiej płatną lub podejmują dodatkową pracę. W ostatnim roku aż 17 proc. pracujących internautów znalazło taką pracę, podczas gdy wśród pozostałych osób było to 11 proc. Internauci pięć razy częściej podnosili swoje kwalifikacje i umiejętności z myślą o możliwości lepszych zarobków. W ostatnim roku nowe kwalifikacje zdobył co czwarty, podczas gdy wśród osób, które z sieci nie korzystają, ledwie co dwudziesty.

Znacznie częściej spotyka internautów także awans zawodowy - w okresie ostatniego roku awansowało ponad cztery razy więcej pracujących użytkowników, niż osób niekorzystających. Z drugiej strony, internauci też częściej deklarują, że ominął ich awans zawodowy (5,7 proc. zatrudnionych użytkowników i 3,8 proc. niekorzystających). Dodatkowo 2 proc. z nich zostało przeniesionych na niższe stanowisko; pracownikom, którzy nie używają internetu takie sytuacje zdarzały się rzadziej.

Internauci znacznie częściej zaczynają własną działalność gospodarczą (w okresie ostatniego roku, trzy razy częściej niż osoby niekorzystające).

\subsubsection{Dzieci w sieci i „komputer dla ucznia”}

W tej części przedstawiona zostanie analiza korzystania z komputerów wśród dzieci w wieku szkolnym. Jak pokazaliśmy wcześniej posiadanie dzieci w wieku szkolnym, a także młodszych, jest jednym z najistotniejszych czynników sprzyjających posiadaniu komputerów i internetu. Po części jest to również efekt tego, że małe dzieci ma w tej chwili pokolenie osób, które komputerów korzystają już od jakiegoś czasu i często zapoznawały się z nimi samemu chodząc do szkoły bądź studiując. Przedstawione tu analizy mają znaczenie również w kontekście rozważanego w tym roku pomysłu „laptopów dla uczniów”, przewidującego zakup komputerów dla uczniów szkół podstawowych.

W gospodarstwach, w których są dzieci, komputery i internet występują znacznie częściej niż w pozostałych gospodarstwach. Zaledwie kilka procent dzieci nie posiada w domu komputera. Wśród dzieci chodzących do szkoły podstawowej jest to około 7 proc. W każdym roczniku ponad 80 proc. dzieci i młodzieży ma dostęp do internetu w domu, dotyczy to nawet niemowląt (por. wykres 7.4.12). Dla gospodarstw domowych z dziećmi, które nie mają komputera i/lub dostępu do internetu, praktycznie jedynym powodem takiego stanu rzeczy jest sytuacja finansowa i brak odpowiednich środków.

- komputer z dostępem do internetu $\quad$ sam komputer $\quad$ brak ze względów finansowych

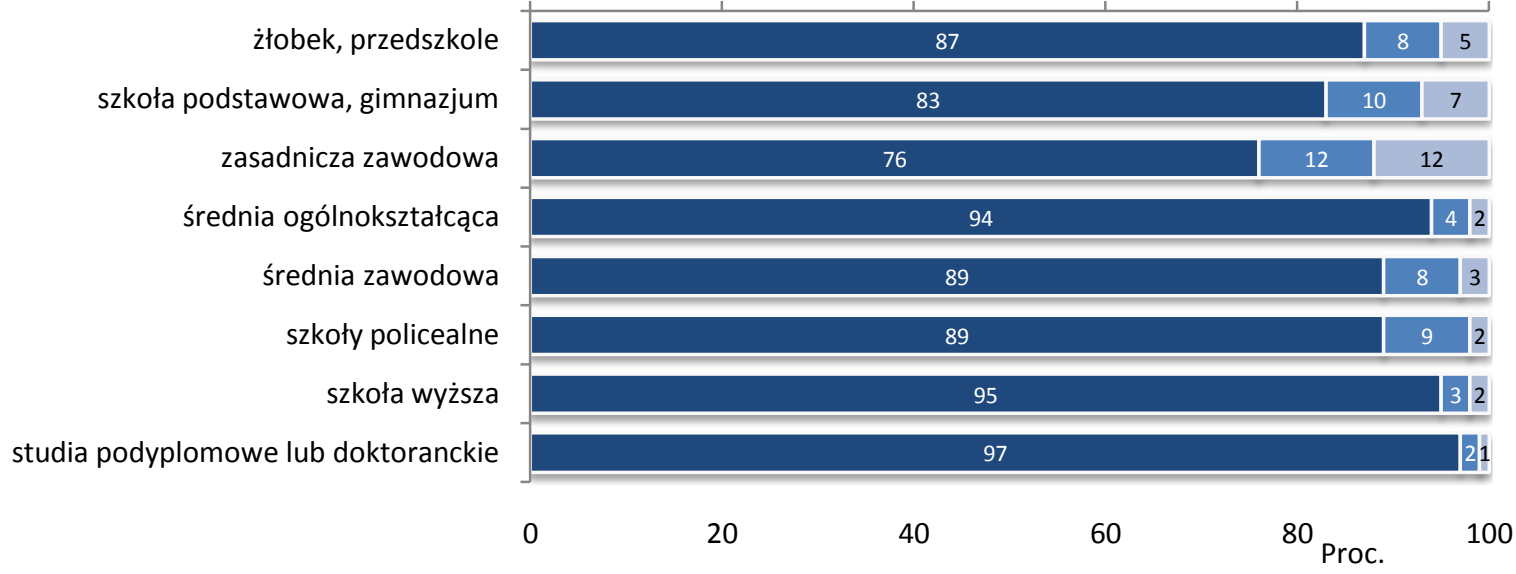

Wykres 7.4.12. Dostępność komputerów i internetu w gospodarstwach domowych osób uczqcych się w zależności od poziomu nauki.

Zdecydowana większość dzieci dorasta mając komputer w swoim otoczeniu i obserwując jak korzystają z niego starsi domownicy. Technologie ICT są dla nich rzeczywistością zastaną, czymś zupełnie naturalnym, przez co też proces nauki korzystania przebiega zupełnie inaczej niż u osób znacznie starczych, którym trudniej zmienić wcześniejsze przyzwyczajenia i przystosować się do korzystania z nowych technologii. Nie dziwi więc, że pierwsze próby korzystania z komputerów zaczynają się bardzo wcześnie. Z komputerów korzysta już kilkanaście procent trzylatków. Wraz z wiekiem szybko rośnie odsetek dzieci używających domowego komputera. Według deklaracji rodziców korzysta połowa pięciolatków (wykres 7.4.13).

Warto szczególnie przyjrzeć się dzieciom rozpoczynającym naukę w szkole. Większość z nich zaczęła korzystać z komputerów jeszcze przed pójściem do pierwszej klasy. Wśród dzieci mających obecnie 7 lat, z których większość poszła po raz pierwszy do szkoły we wrześniu 2010, aż 79 proc. korzystało z komputera w domu w 
momencie realizacji badania. Wśród dzieci będących w 3-4 klasie, 90 proc. korzysta z komputera w domu. Pozostałe nie korzystają zapewne wyłącznie dlatego, że ich rodzin na komputer nie stać.

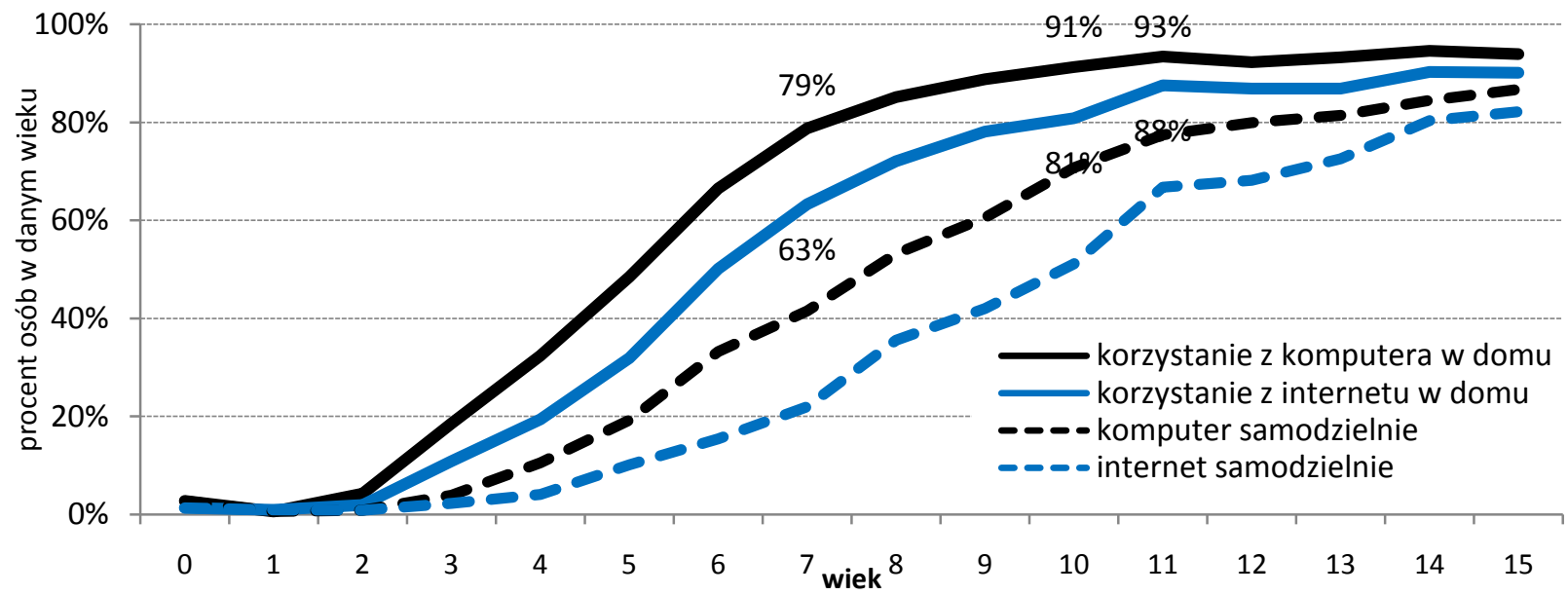

Wykres 7.4.13. Korzystanie z komputerów i internetu $w$ domu przez dzieci i młodzież.

W świetle przedstawionych tu wyników warto przeanalizować zgłoszony kilka miesięcy temu przez Ministerstwo Infrastruktury pomysł „laptop dla ucznia”. Pierwotnie zaproponowano, aby laptopa dostawali wszyscy uczniowie idący do szkoły podstawowej. Sam pomysł ewoluował, dyskusje nad programem wciąż trwają i jego ostateczny kształt nie jest ustalony. Tym bardziej warto wykorzystać dane zebrane w tegorocznej Diagnozie w celu rozważenia, co warto zrobić i na ile powszechny powinien być to program.

Ważnym pytaniem związanym z programem „laptop dla ucznia” jest to, czy komputery przeznaczone dla uczniów mają być używane wyłącznie w szkole, czy również uczniowie powinni mieć możliwość zabrania ich do domu. Zdecydowana większość dzieci rozpoczynających szkołę ma w domu komputer. Zaledwie 7 proc. dzieci nie ma komputera, a około 15 proc. dostępu do internetu. Niewątpliwie jest więc grupa gospodarstw domowych, którym warto pomóc, szczególnie że przyczyny braku technologii w tych domach są przede wszystkim finansowe. Bez odpowiedniego wsparcia, dzieci z tych rodzin nie mają szans na korzystanie z komputerów i internetu w domu. Należy też pamiętać, że dla wielu dzieci obecność komputera w domu niekoniecznie oznacza szansę na bardziej swobodne korzystanie. Bardzo często sprzęt ten wykorzystywany jest przede wszystkim przez innych domowników. Zaledwie około 40 proc. dzieci uczęszczających do szkół podstawowych mieszka w gospodarstwach domowych, w których jest więcej niż jeden komputer.

Laptop, którego uczeń mógłby zabierać do domu dawałby też szanse pozostałym domownikom na lepszy kontakt z komputerem i internetem. Wśród osób mieszkających z dziećmi w wieku 10-13 lat z internetu korzysta 25 proc. nieposiadających dostępu do internetu oraz 78 proc. tych, którzy dostęp posiadają. Choć w gospodarstwach domowych, w których mieszkają dzieci w wieku 10-13 lat, dostęp do komputera ma 92,8 proc. a dostęp do internetu 83,9 proc. osób w wieku 16 i więcej lat, to jednak korzysta z nich znacznie mniej. Z internetu korzysta 68,9 proc. osób w wieku 16+, co oznacza, że aż 15 proc. to osoby posiadające dostęp lecz niekorzystające. Obecność dodatkowego komputera używanego przez dziecko mogłaby pomóc im rozwinąć kompetencje korzystania, a także znaleźć motywację do używania internetu.

Obecnie polska szkoła bardzo słabo wykorzystuje fakt tak powszechnego posiadania komputerów i internetu przez uczniów. Warto pamiętać, że dzieci poświęcają znacznie więcej czasu na korzystanie z komputerów i internetu w domu niż w szkole. Dlatego też niezmiernie istotne jest, aby szkoła promowała mądre wykorzystanie domowego sprzętu. Rozdanie laptopów uczniom samo w sobie niewiele zmieni, jest co najwyżej tylko pierwszym krokiem do zmiany systemu edukacji. Niezbędne jest natomiast zdefiniowanie roli komputerów i internetu w procesie edukacji i zmiana programów nauczania. W szczególności nacisk nie powinien być kładziony na naukę kompetencji informatycznych, które dzieci i tak opanowują dość wcześnie same, ale przede wszystkim na naukę kompetencji informacyjnych - tj. pracy z informacją, wyszukiwania, oceny wiarygodności, weryfikacji źródeł, przetwarzania i krytycznej analizy informacji, itp.

Bardzo ważną kwestia, jest również dostępność treści i materiałów edukacyjnych. Wydaje się to być znacznie istotniejszym zagadnieniem niż dostarczanie samego sprzętu uczniom. Państwo, dbając o upowszechnienie edukacji, wyrównywanie szans uczniów, powinno zadbać o dostępność otwartych treści edukacyjnych.

\subsubsection{Usługi publiczne przez internet}

Jednym z często przywoływanych aspektów rozwoju społeczeństwa informacyjnego jest e-administacja, czyli możliwość zapewnienia lepszej komunikacji w kontaktach pomiędzy obywatelami a instytucjami publicznymi, a także pomiędzy różnymi urzędami. W Polsce powoli rozwijane są kolejne usługi publiczne oferowane przez sieć i 
coraz więcej różnych spraw można w internecie załatwić. Również coraz więcej informacji publicznych jest możliwych do znalezienia w sieci.

Analizy sposobu korzystania $\mathrm{z}$ internetu pokazują, że coraz więcej użytkowników internetu korzysta $\mathrm{z}$ informacji zamieszczanych na stronach instytucji publicznych. W 2005 roku uzyskiwanie informacji z takich stron deklarowała połowa internautów, a obecnie jest to 62 proc. użytkowników. Warto też pamiętać, że w okresie tych sześciu lat liczba osób korzystających z internetu wzrosła prawie dwukrotnie. Znacząco większy jest również odsetek osób, które deklarują ,pobieranie lub wypełnianie formularzy urzędowych przez internet”. Obecnie taki sposób korzystania z internetu przynajmniej od czasu do czasu deklaruje 56 proc. użytkowników, podczas gdy sześć lat temu było to 35 proc.

Oprócz takich ogólnych kontaktów $\mathrm{z}$ administracją publiczną w sieci warto przyjrzeć się konkretnym elektronicznym usługom publicznym. W dyskusjach o rozwoju elektronicznej administracji w Polsce pojawia się wiele zastrzeżeń dotyczących tempa i kierunku tych zmian. Jednym z głównych, jest zarzut koncentracji na rozwoju usług publicznych dostępnych w sposób elektroniczny dla obywatela, pomimo stosunkowo rzadkich sytuacji, w których obywatele $\mathrm{z}$ danego typu usług korzystają (bo jak często można wymieniać dokumenty?). W zamian postulowane jest przede wszystkim usprawnienie procesów wewnątrz administracji i racjonalizacja procesów i procedur administracyjnych w oparciu o wykorzystanie technologii informacyjno-komunikacyjnych. W niniejszej części raportu przyjrzyjmy się jakie jest deklarowane zapotrzebowanie Polaków na usługi publiczne dostępne drogą elektroniczną, oraz jak zmieniało się ono w ostatnich czterech latach.

Podobnie jak w ubiegłych latach, również w tej edycji badania zadane zostało pytanie o preferencje odnośnie sposobów załatwiania różnych spraw urzędowych. W pytaniu tym uwzględnione zostały różne stopnie wykorzystania internetu. Dla każdej z kilkunastu spraw głowa gospodarstwa domowego miała możliwość zadeklarowania, czy przewiduje załatwianie takiej sprawy, a jeśli tak, to czy chciałaby mieć możliwość wykorzystania przy tym internetu. Dodatkowo rozróżniane były dwa poziomy wykorzystania sieci - po pierwsze, tylko uzyskanie informacji (i załatwianie danej sprawy urzędowej w sposób tradycyjny), a po drugie, załatwianie całej sprawy przez internet.

Wykres 7.4.14 przedstawia odsetki gospodarstw domowych zainteresowanych załatwieniem danej sprawy od początku do końca przez internet. Jak można zaobserwować, zainteresowanie dostępnością usług publicznych przez sieć nie jest duże. Należy zaznaczyć, że możliwość załatwienia różnych spraw przez internet znacznie częściej chciałyby mieć osoby, które korzystają z internetu i mają do niego dostęp w domu.

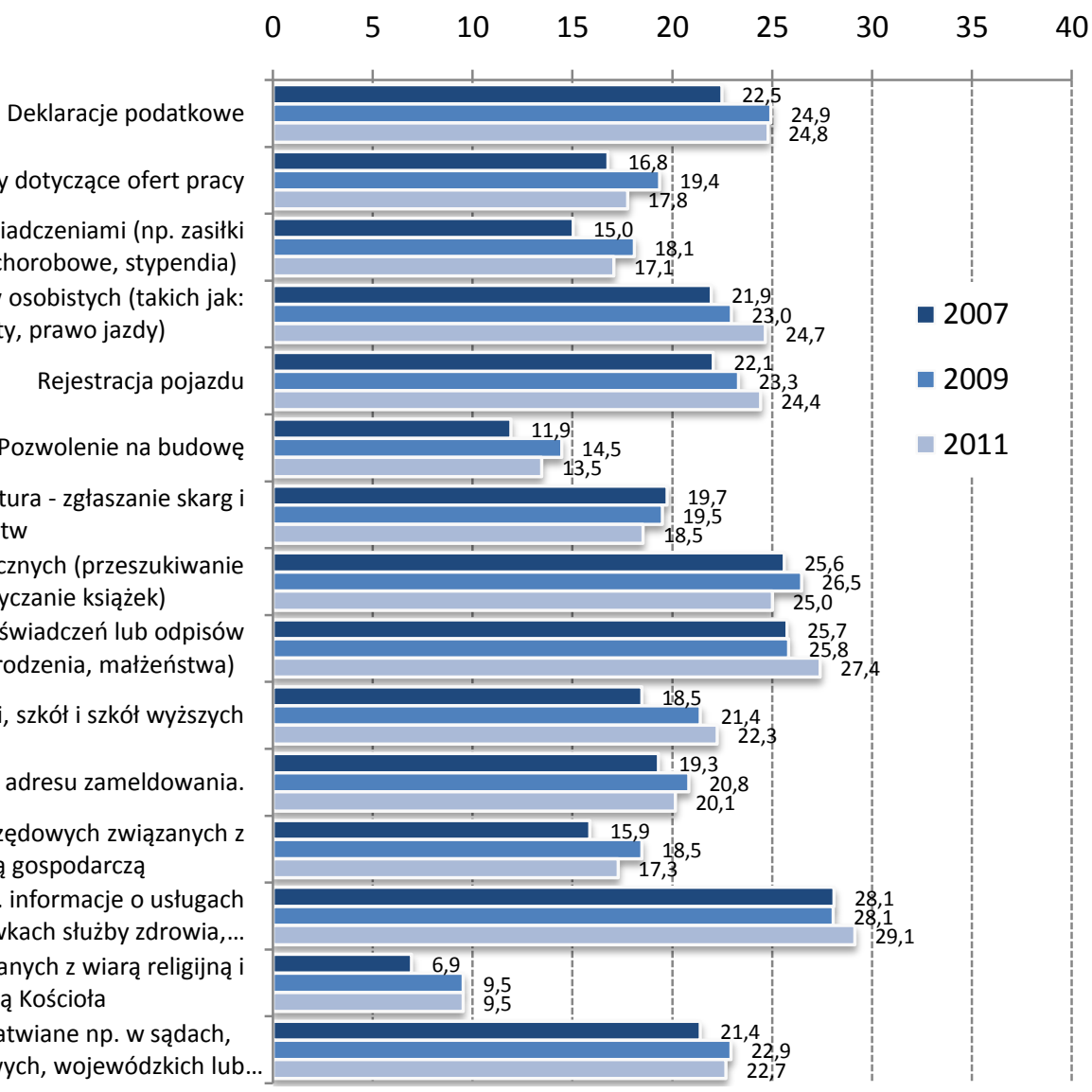

Sprawy związane z zasiłkami i świadczeniami (np. zasiłki dla bezrobotnych, opiekuńcze, chorobowe, stypendia) Sprawy dotyczące dokumentów osobistych (takich jak: paszport, dowód osobisty, prawo jazdy)

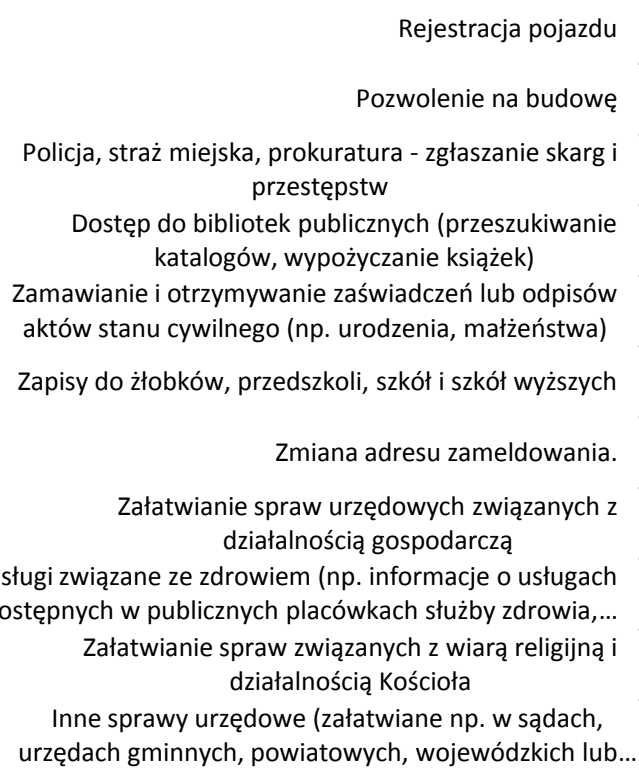

Wykres 7.4.14. Zainteresowanie ushugami publicznymi dostęnymi przez internet - procent osób, które danq sprawe chcialyby w calości załatwiać przez sieć. 
Największym zainteresowaniem cieszą się usługi związane ze zdrowiem, choć one akurat są stosunkowo najmniej dostępne. Dość duża część badanych chciałaby mieć możliwość zamawiania i otrzymywania zaświadczeń lub odpisów aktów stanu cywilnego itp., a także załatwiania spraw związanych z dokumentami osobistymi, deklaracjami podatkowymi (choć w tym wypadku jedna trzecia deklaruje, że woli załatwiać sprawy związane $\mathrm{z}$ podatkami w sposób tradycyjny), czy rejestracją pojazdu, a także możliwość elektronicznego dostępu do bibliotek publicznych. Zdecydowanie najmniejsze zainteresowanie budzi załatwianie spraw związanych z wiarą religijną $\mathrm{i}$ działalnością Kościoła.

Dostępność usług publicznych przez internet była do niedawna często postrzegana jako jeden z ważniejszych elementów rozwoju społeczeństwa informacyjnego. Jednak usług publicznych dostępnych w polskim internecie jest ciągle niewiele. Co więcej, pomimo znaczącego przyrostu liczby użytkowników sieci deklarowana chęć skorzystania z poszczególnych usług praktycznie się nie zmienia. Trudno też liczyć, że udostępnienie możliwości załatwienia spraw przez internet przyczyni się do znacznego zwiększenia motywacji do korzystania z internetu, a przez to dalszego wzrostu liczby jego użytkowników. Dostępność usług publicznych przez internet jest oczywiście konieczna, jednak nie będzie już obecnie znaczącym bodźcem rozwojowym. Kluczowe znaczenie wydaje się mieć obecnie informatyzacja kraju, rozumiana nie jako samo oferowanie usług publicznych przez internet, ale wykorzystanie technologii ICT do usprawnienia funkcjonowania administracji, zarówno wewnątrz, jak i w jej kontaktach z firmami i zwykłymi obywatelami.

\subsubsection{Problem cyfrowego wykluczenia}

We wcześniejszych częściach tego rozdziału pokazane zostały różnice w korzystaniu z komputerów i internetu między różnymi grupami społeczno-demograficznymi, a także związek samego korzystania z internetu z sytuacją na rynku pracy, uczestnictwem w kulturze, a także aktywnością społeczną. Z internetu znacznie częściej korzystają osoby młode, uczące się i lepiej wykształcone. Jednocześnie są to osoby znacznie bardziej aktywne zarówno pod względem zawodowym, jak i społecznym. Różnice w dostępności i korzystaniu z internetu mogą mieć istotne społeczne konsekwencje. Technologie informacyjno-komunikacyjne nie są tylko gadżetami, w coraz większym stopniu stają się także warunkiem dostępu do pełnego uczestnictwa w życiu społecznym. Coraz powszechniejsze wykorzystanie tych technologii i coraz większe ich możliwości, a często również niezbędność w codziennym życiu - nauce, pracy, dostępie do informacji i wiedzy, powoduje, że osoby, które z nich nie korzystają, zaczynają być w coraz większym stopniu wykluczone społecznie. Zjawisko to nazywane jest cyfrowym wykluczeniem.

Problem cyfrowego wykluczenia nie ogranicza się wyłącznie do zjawiska cyfrowego podziału (digital divide), czyli systematycznych różnic $\mathrm{w}$ dostępie i korzystaniu $\mathrm{z}$ komputerów i internetu pomiędzy osobami o różnym statusie społeczno-ekonomicznym (wykształceniu, dochodach, zawodzie), pomiędzy osobami na różnych etapach życia, mężczyznami i kobietami, a także pomiędzy różnymi regionami. Kluczowe są te różnice związane $z$ dostępem, faktem oraz umiejętnościami korzystania $\mathrm{z}$ technologii informacyjno-komunikacyjnych, które prowadzą do społecznego i ekonomicznego wykluczenia.

Zagrożone wykluczeniem cyfrowym są w Polsce przede wszystkim osoby starsze i słabiej wykształceni. Niewątpliwie większe trudności spotykają również osoby mieszkające w mniejszych miejscowościach i o niższych dochodach w gospodarstwie domowym. Co więcej, różnice te nie dotyczą wyłącznie samego faktu korzystania, ale również umiejętności, wszechstronności korzystania, szczególnie jeśli chodzi o bardziej instrumentalne sposoby użycia komputerów i internetu. Dodatkowo znaczenie najważniejszych z tych różnic nieustannie jest bardzo duże i nic nie zapowiada, aby miało się szybko zmienić.

Jak zostało pokazane wcześniej w tym rozdziale, najważniejsze bariery upowszechnienia wykorzystania komputerów i internetu to przede wszystkim brak motywacji do korzystania, wynikający po części również z braku wiedzy i umiejętności. Ograniczenia finansowe, brak sprzętu, a także brak możliwości technicznych założenia stałego łącza są istotne, ale dla znacznie mniejszej części osób niekorzystających. Niestety większość działań, które są w Polsce podejmowane na rzecz upowszechnienia internetu i przeciwdziałania wykluczeniu cyfrowemu w zbyt dużym stopniu koncentruje się na problemach infrastrukturalnych. Potwierdzają się obawy z poprzednich lat, dotyczące nieskuteczności działań podejmowanych przez administrację państwową i samorządową. Mimo olbrzymich pieniędzy przeznaczonych w ramach Programów Operacyjnych na przeciwdziałanie wykluczeniu cyfrowemu, a także na budowę sieci szerokopasmowych, czy zapewnianie dostępu na etapie ostatniej mili, skala wykluczenia cyfrowego w Polsce nie maleje. Fakt korzystania z internetu wciąż silnie różnicuje społeczeństwo polskie. Konsekwencją tego cywilizacyjnego podziału może być postępujące rozwarstwienie społeczeństwa i społeczne wykluczenie osób, które z tych technologii nie będą potrafiły skorzystać. Dalsze pogłębianie się różnic pomiędzy internautami i osobami niekorzystającymi może być źródłem istotnych problemów społecznych w przyszłości. 